Review

\title{
Single-Chamber Solid Oxide Fuel Cell Technology_From Its Origins to Today's State of the Art
}

\author{
Melanie Kuhn ${ }^{1, \dagger}, *$, Teko W. Napporn ${ }^{2, *}$
}

1 Department of Mechanical Engineering, École Polytechnique de Montréal, Montréal, Québec, H3T 1J4, Canada

2 Équipe Électrocatalyse, Laboratoire de Catalyse en Chimie Organique, UMR CNRS 6503, Université de Poitiers, 86022 Poitiers, France

$\dagger$ Current address: Institute of Multidisciplinary Research for Advanced Materials, Tohoku University, 2-1-1 Katahira, Aoba-ku, Sendai 980-8577, Japan

* Authors to whom correspondence should be addressed; E-Mails: kuhn-m@mail.tagen.tohoku.ac.jp (M.K.); teko.napporn@univ-poitiers.fr (T.W.N.); Tel.: +81 22217 5341; Fax: +81 222175343 (M.K.); Tel.: +33 54945 3967; Fax: +33 549453580 (T.W.N.).

Received: 3 November 2009 / Accepted: 31 December 2009 / Published: 15 January 2010

\begin{abstract}
In single-chamber solid oxide fuel cells (SC-SOFCs), both anode and cathode are situated in a common gas chamber and are exposed to a mixture of fuel and oxidant. The working principle is based on the difference in catalytic activity of the electrodes for the respective anodic and cathodic reactions. The resulting difference in oxygen partial pressure between the electrodes leads to the generation of an open circuit voltage. Progress in SC-SOFC technology has enabled the generation of power outputs comparable to those of conventional SOFCs. This paper provides a detailed review of the development of SC-SOFC technology.
\end{abstract}

Keywords: solid oxide fuel cell; single-chamber; mixed-reactant; anode; cathode; electrolyte

\section{Introduction}

Solid oxide fuel cells (SOFCs) are considered as a next generation power generating technology because of their fuel flexibility and high overall efficiency due to the possible use in a cogeneration 
system. However, the elevated operating temperatures impose several challenges on reliability and long-term stability of these fuel cells. Specifically, material degradation, failure of the gas-tight sealing and mechanical stresses due to different thermal expansion coefficients between cell components lead to low cell performance and stability. The elevated temperatures additionally limit the use of SOFCs in small-scale portable power applications. Therefore, reduction of the operating temperature is one of the main challenges in SOFC research.

In conventional dual-chamber SOFCs, fuel and oxidant have to be supplied separately to the respective electrode and any mixing of the two reactant gases has to be avoided. The necessity of separate gas supply imposes complex gas management and gas manifolding, thus complicating not only stack assembly, but also downsizing of SOFC systems. Moreover, gas-tight, high-temperature and mechanically resistant sealing is inevitable in order to separate the cell into leakproof anode and cathode compartments. Sealing is generally achieved using glass or ceramic materials. The advantage of glass sealing is its rigidity and high gas tightness. However, degradation over time as well as thermal stresses during cycling often cause cracks. Sealing by mechanical compression with mica increases thermomechanical strength but results in higher leakage rates. In addition to the gas-tight sealing, the electrolyte has to be fully dense to avoid any gas cross-over between anode and cathode compartments.

The necessity of gas separation and sealing has a severe impact on the mechanical and thermal shock resistance of SOFCs and their long-term stability. Additionally, bulky cell designs limit miniaturization and stack build-up, and severe constraints exist on fabrication technique and material choice, thereby contributing to elevated fabrication costs. In order to avoid those challenges, SOFCs with only one gas chamber, the so-called, single-chamber solid oxide fuel cells (SC-SOFCs), are being developed. SC-SOFCs are operated in mixtures of fuel and oxidant, thus completely eliminating any needs for gas sealing.

To complement previous reviews on SC-SOFCs [1-5], the present review proposes to give a detailed summary on SC-SOFC technology from its early beginnings to the latest achievements. The following sections emphasize the history of this fuel cell technology, the operating principles, followed by the development of different SC-SOFC cell designs, and finally modeling of their performance.

\section{Single-Chamber Solid Oxide Fuel Cells}

SC-SOFCs can be defined as fuel cells with only one gas compartment (thus single-chamber) operating in a non-equilibrium gas mixture of fuel and oxygen [4]. The term "single-chamber" has been introduced in 1999 by Hibino et al. [6], one of the pioneers of SC-SOFC technology, and is generally used. But "one-chamber" [7], "single-compartment" [8], "mixed-gas" [9-11], "mixed-fuels" [12], "mixed-reactant" [1,13,14] and "separator free" [15] fuel cells as well as "SOFCs with reaction-selective electrodes" [16] can also be found in the literature.

In conventional dual-chamber SOFCs, gas-tight sealing together with a dense electrolyte separates the cell into two compartments. The oxidant is then fed to the cathode and the fuel to the anode through separate gas supplies without any intermixing of the two reaction gases (Figure 1a). The difference in oxygen partial pressure between the two separate electrode compartments leads to the establishment of an open circuit voltage (OCV). 
In SC-SOFCs, the cell is located in a single gas chamber and a mixture of fuel and oxidant flows over the cell (Figure 1b). The working principle of SC-SOFCs is therefore based on the selectivity of the electrodes for the respective reactions; that is, the anode must be selective and electrochemically active for oxidizing the fuel and be inert to the reduction of the oxidant, whereas the cathode needs to exhibit selective reduction of oxygen and inertness to the fuel. Thus, both the electrocatalytic activity and the selectivity of the electrodes lead to the generation of the OCV and electricity in SC-SOFCs.

Figure 1. Schematics of (a) dual-chamber and (b) single-chamber SOFC.

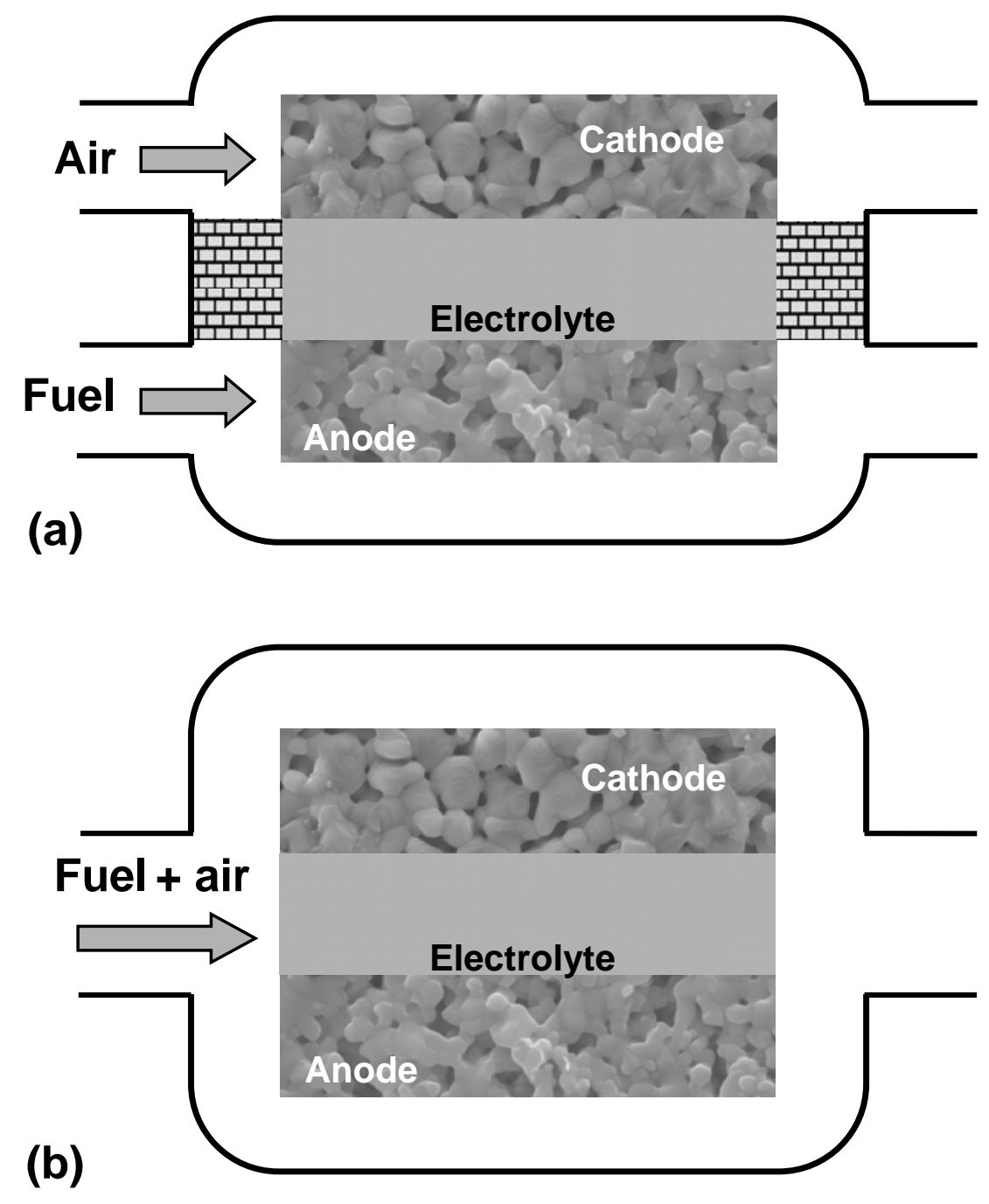

In addition to SOFCs, the single-chamber operating mode has so far also been demonstrated for alkaline fuel cells [17-19], direct-methanol fuel cells (mixed-reactant direct-methanol fuel cells, MR-DMFCs) [1,13,20-23], and microbial fuel cells [24]. MR-DMFCs combine the advantage of reduced explosion risks through operation on diluted methanol-air mixtures at low temperatures (e.g. $90{ }^{\circ} \mathrm{C}$ ) and of overcoming the problems of methanol cross-over and coupled low performance in conventional DMFCs [13].

Table 1 summarizes advantages and challenges of SC-SOFCs. A major drawback of SC-SOFCs is the insufficient selectivity of current electrode materials, resulting in low fuel utilization and cell efficiency $[14,25]$. Therefore, one of the main challenges of SC-SOFC technology consists in finding 
highly selective materials for the next generation of SC-SOFCs with improved efficiencies for practical implementation. Another drawback of SC-SOFCs is the risk of explosion related to working with fuel-air gas mixtures at elevated temperatures.

Table 1. Advantages and challenges of SC-SOFCs.

\begin{tabular}{|c|c|}
\hline Advantages & Challenges \\
\hline $\begin{array}{l}\text { - Sealing-free structure } \\
\text { - Less complex gas manifolding } \\
\text { - Increased thermomechanical stability } \\
\text { - More compact and simplified designs } \\
\text { - Easier stack assembly } \\
\text { - Great potential for miniaturization } \\
\text { - No need for gas-tight electrolyte } \\
\text { - Exothermic reactions to sustain cell } \\
\text { temperature } \\
\text { - New cell designs } \\
\text { - Easier fabrication }\end{array}$ & $\begin{array}{l}\text { - Highly selective and catalytically } \\
\text { active materials necessary } \\
\text { - Low efficiency due to parasitic, } \\
\text { non-electrochemical reactions } \\
\text { - Lower fuel utilization than in } \\
\text { dual-chamber SOFCs } \\
\text { - Risk of explosion for fuel-air } \\
\text { mixtures at high temperatures }\end{array}$ \\
\hline
\end{tabular}

Despite those challenges, however, SOFCs operated in the single-chamber mode exhibit several advantages over conventional SOFCs, making them an interesting alternative to overcome problems associated with dual-chamber operation. Due to the use of a gas mixture, one key advantage of SC-SOFCs consists in the elimination of the gas-tight sealing. Additionally, since the cell is located in one gas compartment, less complex gas manifolding and flow field structures are necessary for reactant supply. The resulting simplified, compact, sealing-free cell structure is expected to show enhanced thermal and mechanical resistance. Also, very thin electrolyte layers with defects, small cracks and pores are acceptable. SC-SOFC fabrication is therefore simpler, and reduced fabrication costs can be expected. Due to the use of a gas mixture, novel cell configurations such as fully porous and single-face SC-SOFCs with coplanar electrodes become possible that could not work under conventional, dual-chamber operating conditions.

Moreover, the exothermic fuel oxidation reactions over the SC-SOFC electrode can cause a rise of the effective cell temperature by up to $100{ }^{\circ} \mathrm{C}$ [26-28], allowing lower operating temperatures and rapid start-ups. This heat release can lead to higher power densities in SC-SOFCs than in dual-chamber SOFCs at nominally lower furnace temperatures. Additionally, the released heat enables thermally self-sustaining cells [25].

The use of a hydrocarbon-air mixture enables internal hydrocarbon reforming over the nickel-based anode catalyst without addition of steam, as carbon deposition can be controlled by adjusting the oxygen content in the fuel-air mixture [5].

Stack assembly and cell packaging are simplified because no sealing and separated gas chambers, gas channels, valves, etc. have to be applied in SC-SOFCs. Significant reduction in mass and volume result, making SC-SOFCs very attractive for portable power applications. The simple, sealing-free design and enhanced thermomechanical stability allow rapid start-ups and shut-downs [25]. Miniaturization of cell designs to sizes in the milli- and micrometer range benefits from the reduced 
number of gas flow channels and the elimination of the gas-tight sealing. Planar cell designs allow for the use of silicon-based microfabrication techniques for the creation of microscale SC-SOFCs [29,30].

\section{Origins of SC-SOFCs}

\subsection{Early works on single-chamber fuel cells}

The concept of single-chamber and mixed-gas operation has its beginnings in the 1950s and 1960s. Back then, the possibility was investigated of using oxyhydrogen gas from radiolytically split water in nuclear reactors to generate electricity by electrochemical recombination of the gas mixture in a fuel cell [17]. Such a $\mathrm{H}_{2}-\mathrm{O}_{2}$ radioisotope power supply was proposed as a nuclear-electric system for applications in space [31]. Already at this stage, the necessity for selective electrodes was pointed out by researchers from Siemens-Varta [32]. Cathodes of active carbon with well dispersed silver were found to be selective for reducing the oxygen from the gas mixture, but not promoting the electrochemical oxidation of hydrogen. Similarly, the reaction selective anode made of platinum and/or palladium should only enable the reaction of hydrogen. A liquid solution of $\mathrm{KOH}$ was proposed as electrolyte. In an oxyhydrogen gas mixture with $9 \% \mathrm{O}_{2}$ and $91 \% \mathrm{H}_{2}$, such an alkaline fuel cell generated an OCV of approximately $1 \mathrm{~V}$ and a maximum current density of $4 \mathrm{~mA} \cdot \mathrm{cm}^{-2}$ at room temperature [17]. A connection of three single cells in series being operated at $60{ }^{\circ} \mathrm{C}$ and a mixture of oxygen and hydrogen with a ratio of $\mathrm{O}_{2}$ to $\mathrm{H}_{2}$ of $1: 2$ led to a power output of $85 \mathrm{~W}$ [32].

In 1961, Grimes et al. [33] proposed a simplified and compact fuel cell design based on an alkaline fuel cell working with a mixture of liquid fuel and oxidant. The cell was composed of a $\mathrm{KOH}$ electrolyte solution to which methanol as fuel and hydrogen peroxide as oxidant could easily be added and mixed. Silver was chosen as cathode with elevated selectivity for hydrogen peroxide and sufficient inertness towards the fuel. At the platinum anode, however, both oxidant and fuel were reacting, creating a chemical short circuit of the system and an unstable OCV. By adjusting the concentrations of methanol and hydrogen peroxide, a stable OCV of $0.81 \mathrm{~V}$ could finally be achieved. A combination of 40 single cells in series connection led to an overall output of $15 \mathrm{~V}$ at $40 \mathrm{~A}$.

Also in 1961, Eyraud et al. [34] developed an all-solid-state electrochemical device operated in a fuel-oxidant gas mixture as an attempt to increase specific power of fuel cells. Reaction selective electrodes with $\mathrm{Pt}$ or $\mathrm{Pd}$ for the anode and $\mathrm{Cu}$ or $\mathrm{Ni}$ for the cathode were combined with a micro-porous, gas-permeable solid alumina or polymer electrolyte. The elaboration of an electrolyte with reduced thickness was found essential to decrease the ohmic cell resistance. In an atmosphere of humidified air, a $\mathrm{Ni}-\mathrm{Al}_{2} \mathrm{O}_{3}-\mathrm{Pd}$ cell delivered an $\mathrm{OCV}$ of $-0.35 \mathrm{~V}$. When hydrogen was added, the OCV was $0.6 \mathrm{~V}$.

In 1965, van Gool [35] further investigated the principles of using gas mixtures in fuel cells. He pointed out that such fuel cells work through heterogeneous catalysis of the fuel and that the catalysts must show high selectivity for the respective reactions. Guidelines for the selection of electrode materials were presented. Based on surface-migration of ions he also proposed fully porous designs and a fuel cell with coplanar, interdigitated electrodes. The first report of operating such a mixed-reactant surface migration cell with coplanar electrodes dates from 1981 where Louis et al. [36] patented a cell design with rectangular, closely-spaced anodes and cathodes on the same side of the 
electrolyte. Series and parallel connection of various single cells on the same substrate was proposed to enhance power output.

\subsection{Dyer's room-temperature single-chamber fuel cell}

In 1990, when using hydrogen that was accidentally contaminated with oxygen, Dyer [37-39] fabricated a fuel cell operating in a $\mathrm{H}_{2}-\mathrm{O}_{2}$ mixture at room temperature with voltages exceeding $1 \mathrm{~V}$ and a power density of $1-5 \mathrm{~mW} \cdot \mathrm{cm}^{-2}$. His device consisted of thin-films of a dense platinum electrode sputtered on a quartz substrate, a sputtered gas-permeable boehmite $(\gamma-\mathrm{AlOOH})$ membrane and finally a porous, gas-permeable Pt electrode sputtered on top of the device (Figure 2).

Figure 2. Schematics of Dyer's room-temperature single-chamber fuel cell.

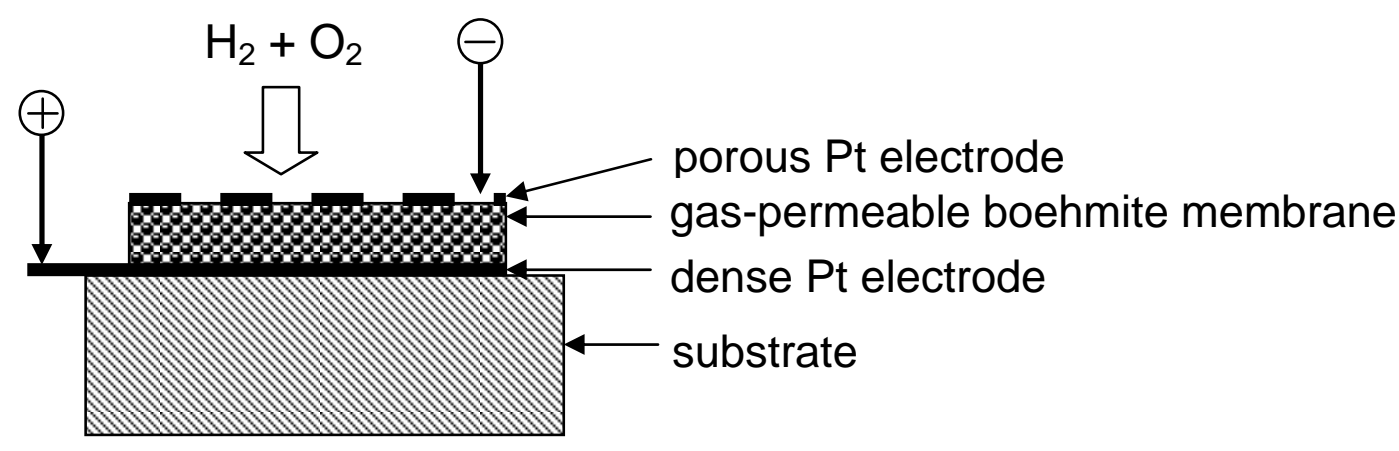

Operation at room temperature and fast response to the power demand were possible because of the very thin electrolyte $(\approx 50 \mathrm{~nm})$. The undesired direct combustion of hydrogen was reduced by operating at high humidification and low total pressure resulting in chemical conversion efficiencies of up to $50 \%$. According to Dyer, the observed voltages weren't due to either known electrochemical and thermoelectric mechanisms or selective gas transport by the membrane. Different electrochemical kinetics of the electrodes and local gas ratio changes were put forward as explanation. Gettering of hydrogen on the permeable electrode and different diffusion rates of fuel and oxidant through the alumina electrolyte could generate a difference of the two gases between the electrodes. The impermeable $\mathrm{Pt}$ electrode then could become oxygen rich and positively charged whereas the permeable Pt electrode showed a negative potential. The efficiency of Dyer's device could be improved by diminishing the direct fuel combustion at the outer electrode by coating the electrode with a hydrogen-permeable and oxygen-impermeable polymer layer [40].

Dyer [38] also suggested that his thin-film, light-weight device working in a gas mixture could simplify fuel cell designs and enable the low-cost fabrication of small systems. The fabrication of cell stacks with a spiral assembly of two single cells connected in parallel [41] and series connection of planar single cells [42] was patented. Corrugated current collectors and interconnects were proposed to ensure easy access of the gas mixture to the electrodes. At that time, hydrocarbons were not suggested as fuel due to the kinetics involved during their oxidation.

Dyer's work raised divergent reactions. On the one hand, a rather skeptical comment [43] questioned the use of fuel cells operated in gas mixtures for real applications. Not only did Dyer's 
device challenge known electrochemistry in order to properly explain its working principles, but also major problems such as low fuel utilization and safety risks due to the use of gas mixtures let the mixed-reactant device appear noncompetitive compared to conventional fuel cell systems. The fact that both electrodes were made of the same material and still delivered an OCV was explained by the formation of an oxide layer on the inner Pt electrode which could cause a difference in catalytic activity. On the other hand, Dyer's fuel cell was welcomed as a new approach for downsizing and simplifying energy generating devices [44]. Compact, small single-chamber fuel cells were considered as potential candidates for high-power applications in electric vehicles, microchips and integrated microelectromechanical (MEMS) devices (e.g., energy conversion and chemical sensing devices).

Inspired by Dyer's discovery, a potential application of a fuel cell being operated in a gas mixture was proposed [45]. A thin-film electrochemical cell with a gold and platinum electrode placed on the same side of a porous electrolyte substrate was operated as a sensor for reducing gases such as $\mathrm{H}_{2}, \mathrm{CO}$, $\mathrm{NH}_{3}$, ethanol vapor, etc. in air. A change in OCV occurred when reducing gases were added to the air atmosphere to which the cell was exposed. The working principle of this gas sensing device was explained by changes in mixed potentials.

Another explanation of the working principle of Dyer's device was proposed by Ellgen [46], who postulated that generation of electrical power in fuel-air mixtures resulted from a combination of chemical and electrochemical reactions involving hydrogen peroxide as well as different catalytic activities of the electrodes for those reactions. At the outer electrode, hydrogen is oxidized to protons which diffuse to the inner electrode and electrochemically react there with hydrogen peroxide formed from the hydrogen-oxygen mixture. A Pt-Pd alloy electrode with high activity for chemical formation and electrochemical reduction of $\mathrm{H}_{2} \mathrm{O}_{2}$ was claimed to function as the cathode whereas $\mathrm{Pt}$ or $\mathrm{Pd}$ electrodes with high activity for hydrogen electro-oxidation and low activity for hydrogen peroxide formation could be used as anodes.

\subsection{Development of SC-SOFCs}

In 1992, a two-chamber solid electrolyte fuel cell was adapted to supply each electrode chamber with fuel-air mixtures [47]. Cells were fabricated from Pt electrodes on an YSZ (yttria-stabilized zirconia) electrolyte and were operated at elevated temperatures in contrast to Dyer's room temperature device. Fuel cell operation was initialized either by an electrical pulse or different gas flow rates between the electrodes. For different electrode materials (e.g. Au and Pt), fuel cell operation was based on different electrochemical exchange rates of the two electrodes. Cell operation was possible using different fuels and at temperatures of up to $450{ }^{\circ} \mathrm{C}$. At $350{ }^{\circ} \mathrm{C}$ for a methane-air mixture, an $\mathrm{OCV}$ of $0.95 \mathrm{~V}$ and a current of $0.065 \mathrm{~mA}$ at $0.64 \mathrm{~V}$ were measured. In another cell design, different gas flow rates were generated between the electrodes, enabling fuel cell operation without an initializing electrical pulse and up to $600{ }^{\circ} \mathrm{C}$.

Hibino and co-workers are the pioneers in implementing the single-chamber operating mode for high temperature SOFCs, making the use of hydrocarbon fuels possible and decreasing the risk of explosion as compared to $\mathrm{H}_{2}-\mathrm{O}_{2}$ mixtures. In 1993, Hibino et al. [48] operated the first $\mathrm{SC}-\mathrm{SOFC}$ in a methane-air mixture at $950{ }^{\circ} \mathrm{C}$. In addition to the experimental demonstration of generating a significant current, outlet gas analysis and electrode potential measurements were used to elucidate the 
working mechanisms. The difference in catalytic activity of the electrodes for the partial oxidation of methane was found to lead to the generation of an OCV.

\section{Single-Chamber Operation}

\subsection{Background on SOFCs}

A SOFC is composed of three main components, the electrolyte and the two electrodes, i.e. anode and cathode. Fuel (e.g., hydrogen) is fed to the anode and is oxidized at the triple phase boundaries (TPB), formed by the electronic conducting, the ionic conducting and the gas phase. $\mathrm{H}_{2}$ and oxygen ions from the electrolyte react to form water and electrons:

$$
\mathrm{H}_{2}+\mathrm{O}^{2-} \rightarrow \mathrm{H}_{2} \mathrm{O}+2 \mathrm{e}^{-}
$$

Via an external circuit the electrons travel to the cathode, where the oxidant (e.g., oxygen) is electrochemically reduced:

$$
1 / 2 \mathrm{O}_{2}+2 \mathrm{e}^{-} \rightarrow \mathrm{O}^{2-}
$$

The oxygen ions are conducted through the electrolyte to the anode to close the electrical circuit. Summing up Reactions (1) and (2) leads to the overall reaction:

$$
\mathrm{H}_{2}+1 / 2 \mathrm{O}_{2} \rightarrow \mathrm{H}_{2} \mathrm{O}
$$

SOFCs, like other fuel cells, are not Carnot-limited. The chemical free energy, available for useful (electrical) work, of the reactant gases (Gibbs free energy, $\Delta G$ ) is directly converted into electrical energy, as given by Equation (4), with $E_{\mathrm{r}}$ the Nernst or reversible cell voltage, $n$ the number of electrons taking part in the reaction per mole of reactant and $F$ the Faraday constant $\left(96,485 \mathrm{C} \cdot \mathrm{mol}^{-1}\right)[49]$ :

$$
E_{\mathrm{r}}=-\frac{\Delta G}{n F}
$$

The cell voltage can also be calculated by the Nernst equation:

$$
E_{\mathrm{r}}=E^{0}+\frac{R T}{2 F} \ln \left(\frac{p_{\mathrm{H}_{2}} p_{\mathrm{O}_{2}}^{1 / 2}}{p_{\mathrm{H}_{2} \mathrm{O}}}\right)
$$

with $R$ the ideal gas constant $\left(R=8.314 \mathrm{~J} \cdot \mathrm{mol}^{-1} \cdot \mathrm{K}^{-1}\right), T$ the temperature in $\mathrm{K}, F$ the Faraday constant, $E^{0}$ the standard reversible cell potential and $p$ the gas partial pressure. The driving force for the migration of the oxygen ions from cathode to anode through the electrolyte results from the oxygen chemical potential or oxygen partial pressure gradient between anode $\left(10^{-15}-10^{-30} \mathrm{~atm}\right)$ and cathode $(0.21 \mathrm{~atm})[50]$. Therefore the Nernst equation can also be written as:

$$
E_{\mathrm{r}}=\frac{R T}{n F} \ln \left(\frac{p_{\mathrm{O}_{2, \text { cathode }}}}{p_{\mathrm{O}_{2, \text { anode }}}}\right)
$$

with $p_{\mathrm{O} 2}$ indicating the oxygen partial pressure at cathode and anode, respectively [49]. 
The efficiency $\varepsilon$ of a SOFC can be expressed as the product of thermodynamic, potential and current efficiency [51]:

$$
\varepsilon=\varepsilon_{\mathrm{th}} \varepsilon_{\mathrm{p}} \varepsilon_{\mathrm{f}}
$$

The theoretical or thermodynamic efficiency $\varepsilon_{\text {th }}$ is given by:

$$
\varepsilon_{\mathrm{th}}=\frac{\Delta G}{\Delta H}
$$

where $\Delta G$ is the Gibbs free energy converted into electrical energy and $\Delta H$ the reaction enthalpy. $\varepsilon_{\mathrm{p}}$ describes the potential efficiency:

$$
\varepsilon_{\mathrm{p}}=\frac{E_{\text {cell }}}{E_{\mathrm{r}}}=-\frac{n F E_{\text {cell }}}{\Delta G}
$$

with $E_{\text {cell }}$ the operating cell voltage and $E_{r}$ the reversible cell voltage. The difference between operating and reversible cell voltage results from ohmic, activation and concentration polarization losses during cell operation.

The current or Faradaic efficiency $\varepsilon_{\mathrm{f}}$ corresponds to the losses that occur due to parasitic side reactions where reactants are consumed instead of in the electrochemical reactions. The current efficiency can also be referred to as the fuel utilization $\varepsilon_{\mathrm{FU}}$ as the utilization and electrochemical conversion of the fuel lead to the generation of an electrical current, and it is given by [49]:

$$
\varepsilon_{\mathrm{f}}=\varepsilon_{\mathrm{FU}}=\frac{I}{I_{\mathrm{f}}}
$$

where $I$ corresponds to the current produced by the cell at the maximum cell power output. $I_{\mathrm{f}}$ represents the theoretical current generated for $100 \%$ electrochemical conversion of the fuel and can be calculated by Faraday's law [49]:

$$
I_{\mathrm{f}}=\frac{m_{\mathrm{F}}^{\prime} \cdot F \cdot n}{M}
$$

where $m_{F}^{\prime}$ is the amount of fuel entering the cell per unit time $(\mathrm{g} / \mathrm{s}), F$ the Faraday constant, $n$ the number of electrons involved in the reactions and $M$ the molar mass of the reacting fuel.

\subsection{Working principles of SC-SOFCs}

Methane-air mixtures are the principal fuel-oxidant gas mixtures used in SC-SOFCs and are used here to describe the working principles of these fuel cells. However, operation with other fuels such as propane [52-54], higher hydrocarbons [52,55] or even liquid fuels [56] has also been reported. The gas mixture is characterized by the fuel-to-oxygen ratio, $R_{\text {mix }}$.

The working principle of SC-SOFCs is based on the difference in catalytic activity and selectivity of the electrode materials for the fuel reaction [5]. In the single-chamber operating mode, two types of catalytic reactions are expected to occur: (i) the heterogeneous catalysis of the fuel (partial oxidation) at the anode $(12,13)$, and (ii) the selective electro-catalysis of fuel oxidation at the anode $(1,14)$ and oxygen reduction at the cathode (2): 


$$
\begin{gathered}
\mathrm{CH}_{4}+1 / 2 \mathrm{O}_{2} \rightarrow \mathrm{CO}+2 \mathrm{H}_{2} \\
\mathrm{CH}_{4}+\mathrm{O}_{2} \rightarrow \mathrm{CO}+\mathrm{H}_{2}+\mathrm{H}_{2} \mathrm{O} \\
\mathrm{CO}+\mathrm{O}^{2-} \rightarrow \mathrm{CO}_{2}+2 \mathrm{e}^{-}
\end{gathered}
$$

A global parameter based on the ratio of fuel and oxygen species in the outlet gas was introduced in [57] to graphically identify the processes occurring in the SC-SOFC system. For an anode-supported cell, partial oxidation of the fuel was confirmed to be the prevailing reaction using this parameter.

The partial oxidation of methane in air has been the subject of various publications [58-64]. Nickel-based catalysts were identified to exhibit activity for promoting the partial oxidation of methane within methane-oxygen gas mixtures [65,66], but temperatures below $1,000{ }^{\circ} \mathrm{C}$ are necessary in order to avoid nickel volatilization and metal loss [59], and almost complete conversion of the methane feed is achieved at temperatures above $700{ }^{\circ} \mathrm{C}[60]$. However, nickel was also found to be active for methane cracking and in oxygen-lean gas mixtures carbon deposition can lead to deactivation of the anode catalyst [65]. Ruthenium oxide catalysts [58,59,65] or Ru-Ni-cermets [67] are also considered for methane partial oxidation at SC-SOFC operating temperatures.

The working principle of SC-SOFCs was first described by van Gool [35] who attributed the possibility of power generation in fuel-air mixtures to the difference in selectivity of the electrodes for the fuel reactions. Figure 3 shows a schematic representation of the operating principle of SC-SOFCs. On the anode catalyst, internal reforming of the hydrocarbon occurs via selective catalytic partial oxidation (12,13). A syngas consisting of hydrogen and carbon monoxide is formed which reacts electrochemically with oxygen ions at the anode $(1,14)$. Additional syngas can be generated by reforming reactions of unused methane reacting with water vapor and carbon dioxide $(15,16)$ :

$$
\begin{gathered}
\mathrm{CH}_{4}+\mathrm{H}_{2} \mathrm{O} \rightarrow \mathrm{CO}+3 \mathrm{H}_{2} \\
\mathrm{CH}_{4}+\mathrm{CO}_{2} \rightarrow 2 \mathrm{CO}+2 \mathrm{H}_{2}
\end{gathered}
$$

The water gas shift reaction (17) converts $\mathrm{CO}$ into $\mathrm{H}_{2}$ which is more easily electrochemically oxidized than $\mathrm{CO}$ :

$$
\mathrm{CO}+\mathrm{H}_{2} \mathrm{O} \rightarrow \mathrm{H}_{2}+\mathrm{CO}_{2}
$$

The cathode is inactive towards the fuel and promotes the electrochemical reduction of oxygen (2).

The selective partial oxidation of the fuel and the selective electrochemical reactions at anode and cathode create a difference of oxygen concentration between the two electrodes. The partial fuel oxidation and depletion of incoming oxygen lead to drop of the oxygen partial pressure at the anode and create a reducing environment, whereas a high oxygen partial pressure depending on $R_{\operatorname{mix}}$ is established at the cathode due to its inertness towards the fuel. This gradient in oxygen partial pressure is the driving force for the fuel cell operation and is at the origin of the OCV according to the Nernst equation (6). In closed-circuit conditions, the electrochemical reactions lead to a net flow of current through the electrolyte and in the external circuit. 
Figure 3. Schematic representation of the single-chamber working principle.

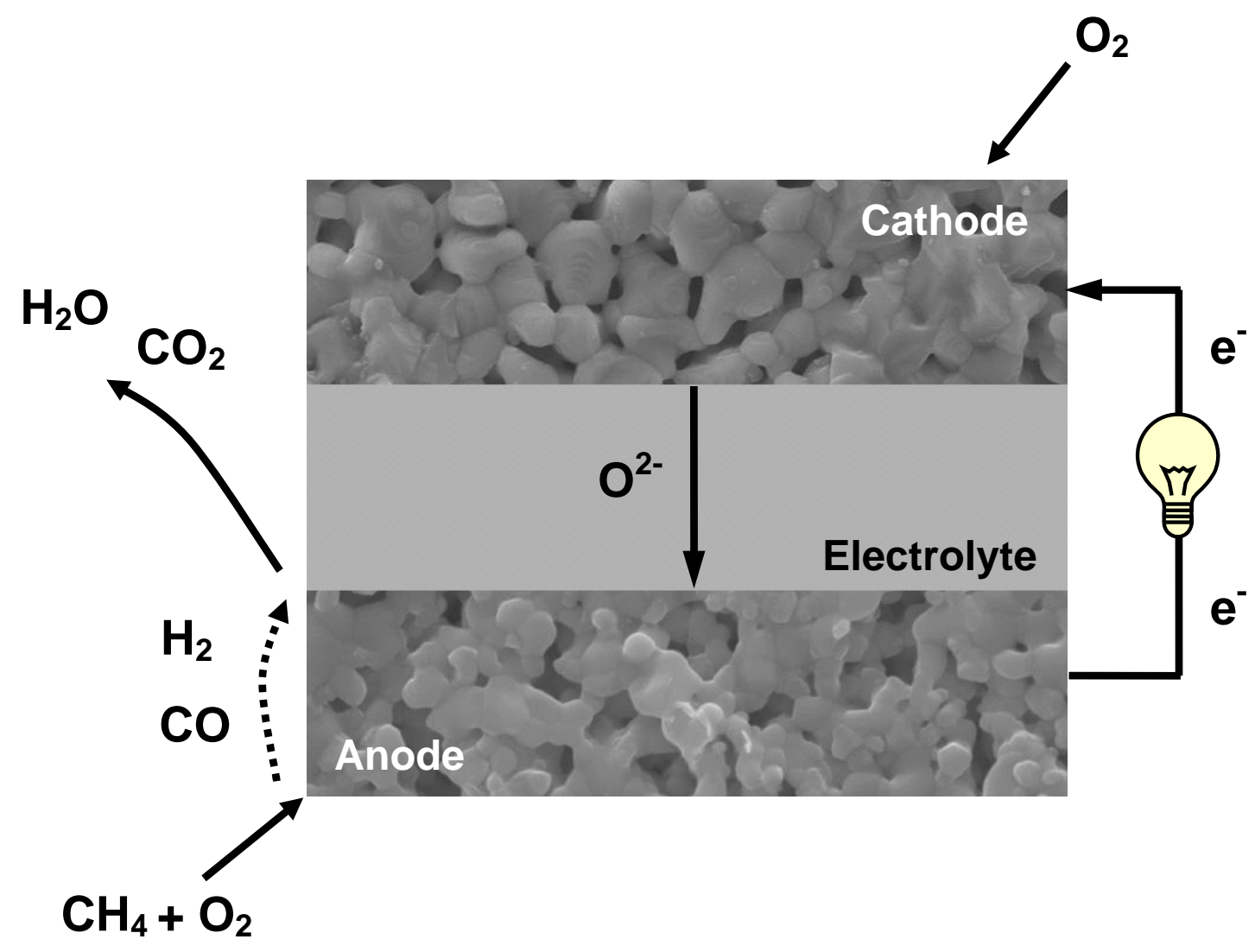

Exhaust gas analysis and half-cell measurements are a suitable means to experimentally demonstrate the SC-SOFC operating principle. Hibino et al. $[48,68]$ specifically used a two-chamber set-up where anode and cathode were examined against a Pt reference electrode. The catalytic activity of Pt and Ni-based anodes for the partial oxidation of methane was translated by the consumption of methane and formation of syngas, whereas the cathode showed limited and low activity for the methane reaction. The partial oxidation of methane and formation of $\mathrm{H}_{2}$ and $\mathrm{CO}$ over the anode catalyst were proposed to occur through the full oxidation of methane followed by steam reforming and reaction of methane with $\mathrm{CO}_{2}$. Additionally, it was found that oxygen partial pressure as well as anode and cathode potentials depended on the catalytic activity of the electrodes for the partial oxidation of methane. Increased activity of the anode and limited activity of the cathode for the fuel reaction led to an increased OCV [69].

Theoretical considerations by Riess [11,70,71] also confirmed that the working principle of SC-SOFCs depends on the difference in selectivity of the electrode materials for the specific reactions. For ideally selective electrodes the performance of a SC-SOFC should be the same as the one of a conventional dual-chamber SOFC. However, real SC-SOFC systems exhibit very low efficiencies $(\sim 1 \%)$ [25] and the insufficient selectivity of current electrode materials is one of the main reasons for the lower performance [70]. The cathode is not totally inert to the fuel, and at the anode, direct, non-electrochemical fuel oxidation (18-20) can occur due to operation at elevated temperatures: 


$$
\begin{gathered}
\mathrm{CH}_{4}+2 \mathrm{O}_{2} \rightarrow \mathrm{CO}_{2}+2 \mathrm{H}_{2} \mathrm{O} \\
\mathrm{CH}_{4}+\mathrm{O}_{2} \rightarrow \mathrm{CO}_{2}+2 \mathrm{H}_{2} \\
\mathrm{CH}_{4}+3 / 2 \mathrm{O}_{2} \rightarrow \mathrm{CO}+2 \mathrm{H}_{2} \mathrm{O}
\end{gathered}
$$

Additionally, the syngas formed by the partial fuel oxidation can also be chemically oxidized according to reactions $(3,21)$ :

$$
\mathrm{CO}+1 / 2 \mathrm{O}_{2} \rightarrow \mathrm{CO}_{2}
$$

These reactions are purely chemical reactions that do not contribute to the generation of electrical power and, according to Equations (8) and (10), cause low thermodynamic and current efficiencies of the SC-SOFC.

Other problems during cell operation are associated with carbon deposition on the anode catalyst surfaces according to the Boudouard reaction (for temperatures below $700{ }^{\circ} \mathrm{C}$ ) (22) and methane cracking (for temperatures above $500{ }^{\circ} \mathrm{C}$ ) (23):

$$
\begin{aligned}
& 2 \mathrm{CO} \rightarrow \mathrm{C}+\mathrm{CO}_{2} \\
& \mathrm{CH}_{4} \rightarrow \mathrm{C}+2 \mathrm{H}_{2}
\end{aligned}
$$

Carbon deposition has a negative impact on the performance and long-term stability of the system, and $R_{\text {mix }} \leq 2$ is recommended to avoid carbon formation [50,59]. In general, a methane-air mixture is preferably to be used with $R_{\text {mix }}$ between 0.85 and 2 [27,50]. A lower limit of the mixing ratio ( $R_{\text {mix }}<0.85$ ) is imposed by the gas mixture becoming explosive. For very low $R_{\text {mix }}(<0.5)$, reoxidation of $\mathrm{Ni}$ might occur, complete fuel oxidation is favored and the amounts of formed $\mathrm{H}_{2}$ and $\mathrm{CO}$ are too low to allow power generation. The range $0.5<R_{\mathrm{mix}}<2$ for suitable operation was confirmed using thermodynamic gas equilibrium calculations [50].

\subsection{Fuel-air mixtures}

SC-SOFCs are generally operated on hydrocarbon fuels mixed with an oxidant (e.g., air or oxygen). The direct use of hydrocarbon fuels by internal reforming on the anode catalyst eliminates the need for prior fuel processing and external reforming systems, therefore increasing the overall system efficiency and decreasing system costs. Due to the presence of oxygen, carbon deposition on nickel-based anodes from internal hydrocarbon reforming is less a problem in SC-SOFCs than under dual-chamber operating conditions. Hydrogen-air mixtures are generally not usable in SC-SOFCs due to their reactivity [72] and the elevated risk of explosion at SOFC operating temperatures [4,73], but were used in $[72,74,75]$ where either anode or cathode were exposed to a hydrogen-air mixture in a double-chamber testing configuration in order to simulate the individual electrode performance under single-chamber conditions. Methane, followed by propane, is the most common fuel used in SC-SOFCs.

Other hydrocarbon fuels were proposed by Hibino et al. [52,55] for low temperature operation. The reactivity of methane was found to be too low to sustain its partial oxidation at temperatures 
below $600{ }^{\circ} \mathrm{C}$, and no power output could be obtained [55]. The use of higher hydrocarbons such as ethane, propane, liquefied petroleum gas and ethanol enabled the generation of an electrical power output at reduced operating temperatures, and the best performance was obtained with ethane as fuel in a temperature range between 400 and $700{ }^{\circ} \mathrm{C}$. Ethane and propane were also confirmed as suitable fuels for operating temperatures between 350 and $450{ }^{\circ} \mathrm{C}$ [55].

Hibino et al. [56] also were the first group to investigate the use of alternative, liquid fuels such as dimethyl ether and ethanol. Using the heating effect generated by the fuel oxidation reactions, operation became possible at temperatures as low as $300{ }^{\circ} \mathrm{C}$.

In order to reduce carbon deposition on Ni-based anodes in dual-chamber SOFCs, humidified hydrocarbon gas can be used. The presence of water vapor enhances the steam reforming reaction of methane (15) and favors the water gas shift reaction leading to the formation of $\mathrm{CO}_{2}$ (17). Additionally, the carbon compounds are oxidized and methane cracking is reduced. SC-SOFCs are generally operated under dry-gas conditions where water vapor is formed internally through the various reactions occurring within the system. Napporn et al. [76] revealed a higher performance at $R_{\text {mix }} \geq 1.2$ for the direct use of humidified gas in SC-SOFCs as compared to dry gas when the water was added after methane and oxygen were introduced into the system. Adding water directly to methane during $\mathrm{NiO}$ reduction led to a decrease of performance probably due to the incomplete reduction of the nickel cermet. The presence of water vapor in the reaction gas led to a temperature drop of 10 to $35{ }^{\circ} \mathrm{C}$ compared to the dry gas operation, indicating that the addition of water promoted the endothermic methane steam reforming reaction.

\subsection{Electrode selectivity and catalytic activity}

Selectivity refers to reaction selectivity between electrochemical and chemical reactions. The chemical reaction of partial fuel oxidation is tolerated and wanted, whereas the complete fuel oxidation is not desirable. The latter should only be achieved by electrochemical reactions [14]. Specifically, the anode needs to be active and selective for the partial oxidation of the fuel $(12,13)$ and the electrochemical oxidation of the produced syngas $(1,14)$ while at the same time it should not promote the complete fuel oxidation. The cathode should not enable any fuel reactions but only the electrochemical reduction of oxygen (2). The lack of sufficient selectivity of anode and cathode materials is however a problem in current SC-SOFCs, and significantly reduces performance due to non-desired reactions. The electrode materials are not ideally selective for the specific anodic and cathodic reactions, and in addition they are not completely inert to the direct chemical oxidation reaction of the fuel. This lack of selectivity leads to low fuel utilization $(<10 \%)$ according to Equation (10) and low overall efficiency. Moreover, high flow rates and fuel-rich gas mixtures that are used to achieve a voltage and power output [14], contribute to elevated fuel waste. However, adjusting $R_{\text {mix }}$, flow rate, temperature and gas flow around the cell favors only certain reactions and can compensate for insufficient selectivity [14,77].

Electrode selectivity can be studied by measuring voltage and power output, performing exhaust gas analysis, calculating gas conversion rates or determining the ratio of generated current to the rate of fuel consumption [14]. Additionally, material screening can be performed by examining the catalytic activity of the electrode material for the direct chemical oxidation [14]. Among conventionally used 
fuel cell materials, Ni showed low activity in such a screening test in a methane-air mixture. YSZ was inert at temperatures below $700{ }^{\circ} \mathrm{C}$, LSM $\left(\mathrm{La}_{0.8} \mathrm{Sr}_{0.2} \mathrm{MnO}_{3-\delta}\right)$ was reduced by methane, and SDC (samarium-doped ceria) was highly active and can therefore only be used at low temperatures. Investigations on the catalytic activity of Ni-CGO $\left(\mathrm{Ce}_{0.8} \mathrm{Gd}_{0.2} \mathrm{O}_{1.9}\right)$ anodes and $\mathrm{SSC}\left(\mathrm{Sm}_{0.5} \mathrm{Sr}_{0.5} \mathrm{CoO}_{3-\delta}\right)$ cathodes based on reaction rate measurements revealed that both electrodes promoted the fuel reactions, but the anode was more active [4].

Hibino et al. $[6,69]$ investigated the catalytic activity of the electrode materials towards the fuel-air mixture by analyzing the exhaust gases of each electrode in a dual-chamber testing setup. The electrode material was located in one chamber and was exposed to a fuel-air mixture. Its activity was measured against a Pt counter electrode which was situated in the second chamber and was exposed to air. Nickel was shown to exhibit higher catalytic activity for methane conversion than the LSM cathode. Electrode potential measurements against a Pt reference electrode led to the establishment of an optimal operating temperature range between 550 and $650{ }^{\circ} \mathrm{C}$ based on the catalytic activities of the Ni-YSZ and LSM electrode materials. Kellogg et al. [72,74,78] used the dual-chamber setup to compare a Ni-YSZ anode against a $\mathrm{La}_{0.8} \mathrm{Sr}_{0.2} \mathrm{Co}_{0.2} \mathrm{Fe}_{0.8} \mathrm{O}_{3}$ (LSCF)-Ag cathode by measuring the OCV for different fuel-air mixtures. One electrode was exposed to gas compositions ranging from pure fuel (5\% hydrogen and 95\% argon) to fuel-lean gas mixtures whereas pure oxidant was used at the counter electrode. With increasing oxygen/fuel content at the anode/cathode side, the OCV became temperature dependent and dropped. The Ni-YSZ anode was found to lose its activity at temperatures below $550{ }^{\circ} \mathrm{C}$ whereas the LSCF cathode became active for fuel oxidation at temperatures over 400 ${ }^{\circ} \mathrm{C}$. Exhaust gas analysis revealed that Ni-YSZ anodes catalyzed the partial oxidation of propane at temperatures over $650{ }^{\circ} \mathrm{C}$ [79] and that temperatures above $600{ }^{\circ} \mathrm{C}$ were necessary for the partial oxidation of methane over Ni-SDC anodes [80]. For operation at reduced temperatures, the catalytic activity of Ni-based anodes can be enhanced by addition of metal oxides [80-83].

The reactivity of cathode materials towards fuel reactions can be decreased by increasing the sintering temperature and thereby reducing porosity and active surface area of the sintered cathode $[53,57]$. Moreover, by respecting an upper operating temperature limit, the activity of cathode materials can be further limited [55,57]. A comparative study of the catalytic properties of perovskite-type cathodes showed that LSC $\left(\mathrm{La}_{0.6} \mathrm{Sr}_{0.4} \mathrm{CoO}_{3}\right)$, SSC and LSCF cathodes already exhibited high catalytic activity for methane conversion at low temperatures around $400-450{ }^{\circ} \mathrm{C}$ whereas LSM and BSCF $\left(\mathrm{Ba}_{0.5} \mathrm{Sr}_{0.5} \mathrm{Co}_{0.8} \mathrm{Fe}_{0.2} \mathrm{O}_{3-\delta}\right)$ became active at temperatures above $600{ }^{\circ} \mathrm{C}$ [84]. Due to its catalytic activity for methane oxidation, LSCF was additionally shown to function as an anode in conventional dual-chamber SOFCs $[85,86]$.

Further details on the catalytic activity of anode and cathode materials investigated for single-chamber operation can be found in the materials sections.

\subsection{Fuel utilization and fuel cell efficiency}

Fuel utilization of SC-SOFC systems is commonly evaluated by calculating the current efficiency according to Equation (10) $[28,87,88]$. However, this approach does not take into account the utilization of fuel for the generation of heat by the exothermic fuel reactions [26,89]. This heat may be used to thermally self-sustain the cells without any external heating [25], thereby increasing the overall 
system efficiency. The fuel utilization has therefore been defined by Hao et al. [89] as the ratio of the enthalpy drop of the fuel between cell inlet and outlet to the heat release generated by the oxidation of the incoming fuel:

$$
\varepsilon_{\mathrm{FU}}=1-\frac{m_{\mathrm{F}, \text { out }}^{\prime} \Delta H_{\mathrm{F}, \text { out }}}{m_{\mathrm{F}, \text { in }}^{\prime} \Delta H_{\mathrm{F}, \text { in }}}
$$

The heat release by the inlet fuel equals the product of the mass flow rate of the incoming fuel $m_{\mathrm{F} \text {,in }}^{\prime}$ and its combustion enthalpy change $\Delta H_{\mathrm{F}, \text { in }}$, whereas $m_{\mathrm{F} \text {,out }}^{\prime}$ and $\Delta H_{\mathrm{F}, \text { out }}$ are the mass flow rate and combustion enthalpy change of the exhaust fuel.

Alternatively, a fuel utilization factor (F.U.) has been introduced in [27]:

$$
\text { F.U. }=\frac{P_{\max }}{\Delta H_{\text {react }}}
$$

where $P_{\max }$ is the power drawn from the cell at a specific $R_{\text {mix }}$, and $\Delta H_{\text {react }}$ is the reaction enthalpy for the overall reaction in the system corresponding to full oxygen consumption. Maximum fuel utilization is achieved for maximum power drawn from the cell and for full consumption of oxygen from the gas mixture.

In a theoretical evaluation, Demin et al. found a direct dependence of the gas mixing ratio $R_{\text {mix }}$ on fuel utilization [77]. For a single cell, $R_{\mathrm{mix}}=1$ led to the highest fuel efficiency (25\%). If the unreacted fuel gases from the exhaust gas were used in another cell or if the unreacted fuel was directed back to the fuel cell inlet, higher efficiencies could be achieved for practical applications.

Fuel utilization and cell efficiency of real SC-SOFC systems, however, are significantly lower than the ones predicted by Demin et al. Anode-supported SC-SOFCs showed fuel utilization ranging from approximately $1 \%$ [88] to $2.4 \%$ [28] and an efficiency of about $1 \%$ [25]. For a fully-porous SC-SOFC, the fuel utilization was estimated to be $4-8 \%$ [87]. Even lower fuel utilization and cell efficiency (below $0.1 \%$ ) was calculated for SC-SOFCs with coplanar micro-electrodes [90]. These values can be attributed to the occurrence of parasitic reactions in the fuel-air mixture that do not contribute to electricity generation but only to the generation of heat. Current electrode materials are not selective enough to catalyze only the respective electrode reactions and fuel can be lost by the catalytic activity of the cathode materials or the complete oxidation over the anode. Transport of reaction gases from one electrode to another can impede the establishment of an OCV [25], and gas intermixing may enhance reactions that should not be catalyzed on the respective electrode. Additionally, elevated flow rates are found to yield the highest power outputs at the detriment of fuel utilization as a large amount of fuel may pass the cell without reacting. The small size of micro-electrodes can also lead to low fuel utilization. SC-SOFCs in the tubular design seem to compensate for some of the above mentioned issues. Due to the tubular cell design, gas intermixing between anode and cathode is avoided as long as a fully dense electrolyte is used. Moreover, the reaction gases have more time to react over the elongated, tubular electrodes. A fuel utilization of $11 \%$ and an effective efficiency of approximately $5 \%$ were obtained for micro-tubular SC-SOFCs [91]. The low values for fuel utilization and cell efficiency point out the major drawback of present SC-SOFCs and therefore the necessity to thoroughly report fuel utilization and efficiency, which are currently omitted in most publications on SC-SOFCs. 
In addition to non-ideal electrode selectivity and parasitic reactions, efficiency of SC-SOFCs is reduced by the nature of the fuel reactions. Ideally, if direct electrochemical complete oxidation of the hydrocarbon (26) would occur, maximum current could be drawn from SC-SOFCs at elevated efficiencies:

$$
\mathrm{CH}_{4}+4 \mathrm{O}^{2-} \rightarrow \mathrm{CO}_{2}+2 \mathrm{H}_{2} \mathrm{O}+8 \mathrm{e}^{-}
$$

However, real SC-SOFC systems work based on the partial oxidation of the hydrocarbon and electrochemical oxidation of the syngas, where less electrons are generated compared to the maximum possible number of eight electrons according to reaction (26). For the direct electrochemical partial oxidation:

$$
\mathrm{CH}_{4}+\mathrm{O}^{2-} \rightarrow \mathrm{CO}+2 \mathrm{H}_{2}+2 \mathrm{e}^{-}
$$

the current efficiency would be only $25 \%$.

\subsection{Heat production}

The partial as well as direct oxidation reactions of the fuel in fuel-air mixtures are exothermic reactions. The resulting heat release leads to an increase of the cell temperature which thus deviates from the furnace temperature by several degrees. Controlling the overheating and measuring the real cell temperature are necessary to control the system and its performance as well as thermal degradation. At the same time, the generated heat can be used for cogeneration [92], to effectively raise the cell temperature for improved cell performance [5] and to use low furnace temperatures [93], or to thermally self-sustain the SC-SOFCs [25].

A first report on the exothermic effect of the fuel-air mixture on the local anode and cathode temperature was provided by Hibino et al. [93] who measured a temperature increase at the anode by $100{ }^{\circ} \mathrm{C}$ in a butane-air mixture. The difference between furnace and actual cell temperature was then clearly demonstrated by Napporn et al. [26]. Due to exothermic reactions within the methane-air mixture, the actual cell temperature was measured to be by 35 to $45{ }^{\circ} \mathrm{C}$ higher than the set furnace temperature for an electrolyte-supported Ni-YSZ |YSZ | LSM cell. The overheating was measured by fixing a thermocouple directly on the electrolyte, in addition to a thermocouple placed in the testing furnace. The overheating effect was found to be enhanced by using platinum current collectors due to the catalytic activity of platinum for methane.

Napporn et al. [27] further monitored the overheating resulting from the catalytic reactions occurring under single-chamber operation. Blank YSZ substrates showed negligible overheating as no methane combustion or oxidation took place. An increased difference between sample and furnace temperature was observed for electrolytes coated with Ni-YSZ which led to higher overheating than samples coated with LSM. Additionally, overheating increased almost linearly with increasing flow rate, indicating a proportional heat release by hydrocarbon oxidation with flow rate. These results suggested that the increase in temperature was directly due to the catalytic reactions promoted by the electrode materials: the anode coated samples giving rise to higher overtemperatures $\left(10\right.$ to $\left.35^{\circ} \mathrm{C}\right)$ because of the enhanced activity of the nickel-based anode for methane oxidation. 
In addition to an increase of the mean cell temperature, the exothermic reactions were also found to cause a local temperature gradient between fuel inlet and outlet cell side [92,94,95]. The local temperature was obtained by measuring the ohmic resistance of the electrolyte for an electrolyte-supported cell with a small cathode being positioned at the inlet, the center or the outlet cell side [92,94]. At $R_{\text {mix }}=1$, the temperature at the inlet was up to $135{ }^{\circ} \mathrm{C}$ higher than the furnace temperature whereas at the center and outlet position the difference was $90^{\circ} \mathrm{C}$ and $75{ }^{\circ} \mathrm{C}$, respectively. The higher temperature at the inlet position was attributed to fast reaction processes occurring within a freshly supplied fuel-air mixture. Similar observations of thermal gradients along the cell length were found for a micro-tubular SOFC operated in a methane-air mixture where the anode temperature was monitored as a function of the cathode position along the micro-tube [95]. In both studies [92,94,95], the local differences in temperature also led to a gradient in OCV and power output along the cell length. In addition, the inhomogeneous temperature variations could enhance thermal stresses and cell degradation, and might explain the loss of nickel occurring at the fuel inlet side as reported in [96], and damages of cathode and anode near the fuel inlet [95].

\subsection{Testing chamber design}

The design of the testing chamber plays a significant role with respect to cell performance. The testing setup design should permit flow of the reaction gases with reduced stagnation and exposure of the reaction products to the electrodes [7]. Additionally, the use of small diameter gas channels and small chamber volumes can lead to higher cell performance by increasing the gas flow rate and generating higher gas velocity [87]. An open chamber design should be preferred to closed chambers where intermixing of gases has a negative impact on cell performance [97]. Additionally, testing chambers should allow uniform, continuous flow of the fuel-air mixture to anode and cathode [27]. Differences in cell resistance and performance were obtained when using two different designs of gas distribution plates [94]. Both designs had evenly arranged posts to create a uniform mixing and distribution of the gas mixture over the electrode. However, a closed design with walls around the edges of the plate was found to prevent lateral gas leakage and performance drops by constraining the gases over the electrode.

\subsection{Current collection}

Single-chamber operating conditions impose several constraints on the choice of current collector material. The current collector material should be inert to the fuel-air mixture and have a sufficiently high thermal stability to withstand the temperature increase during SC-SOFC operation. Although platinum has generally been used for current collection in SC-SOFCs, the actual working temperature of a SC-SOFC was shown to be by 80 to $160{ }^{\circ} \mathrm{C}$ higher than the furnace temperature when platinum was employed as current collector material [26,27]. Additionally, the catalytic activity of platinum towards the fuel-air mixture was found to enhance the catalytic activity of the anode material [4] and boost the performance of the cell [98]. In order to avoid direct contact between the reaction gases and Pt current collectors, the use of integrated platinum current collectors, embedded inside each electrode layer, was therefore proposed [99-101]. However, as the reaction gases pass through the porous 
electrodes to the interface with the electrolyte, interaction of $\mathrm{Pt}$ with the fuel-air mixture can still be possible within the electrodes and the effect of the catalytic activity of Pt cannot necessarily be impeded.

Gold current collectors were found to be inert towards the fuel and cause no overheating in a methane-air mixture [26]. However, gold is known to react with nickel and form a nickel-gold eutectic at temperatures above $800{ }^{\circ} \mathrm{C}$. This alloy has poor catalytic activity towards the fuel, and through its melting at temperatures above $950{ }^{\circ} \mathrm{C}$ the gold current collectors and nickel electrode can be severely damaged [26]. Silver current collectors also showed reduced structural stability in methane-air mixtures and through silver oxidation, melting and vaporization, mechanical failure of the silver wire occurred during long-term cell operation [102].

In addition to the choice of suitable current collector materials, efficient current collection is a major challenge in SC-SOFCs with coplanar micro-electrodes. Applying current collectors over the whole electrode surface area of interdigitated or otherwise shaped coplanar micro-electrode arrays would require precisely shaped current collectors to fit either on top of the electrode surface or inside the electrodes. Short circuits between closely-spaced anodes and cathodes might easily occur through the current collector. Therefore, current collectors are generally employed only on a small segment of the electrode which connects together the single lines of one electrode. For this current collection configuration, long conduction paths along the electrode lines towards the current collector are expected to cause excessive ohmic resistance [103]. An experimental evaluation of the effect of current collection confirmed an increase in cell resistance when the current was collected only on the connecting line as compared to current collection on the whole electrode surface [104]. Additionally, a performance drop of over $50 \%$ in power density was observed for Ni-YSZ|YSZ|LSM,LSM-YSZ cells where the connecting segment represented about $20 \%$ of the total electrode area. Enhancing the conductivity of the anodes by increasing the nickel content did not yield any performance improvement due to nickel loss and reduction-oxidation cycles.

\subsection{Flammability and explosion limits of methane-air mixtures}

As mixtures of methane and air at elevated temperatures are used in SC-SOFCs, it is useful to know the explosion and flammability limits of such mixtures. The concentration of a combustible gas in air (or pure oxygen) determines whether there is a danger of combustion. With decreasing fuel concentration, the gas mixture becomes poor in combustible gas and reaches its lower flammability limit (LFL). At this point, the mixture contains too little fuel to sustain combustion. The upper flammability limit (UFL) is reached with increasing fuel concentration. At this point, the mixture is too rich in fuel and too poor in oxygen to enable combustion. The LFL and UFL for methane in air at $25{ }^{\circ} \mathrm{C}$ and $1 \mathrm{~atm}$ are 5 and $15 \mathrm{vol} \%$ respectively $[105,106]$. For methane concentrations between the LFL and UFL, the mixture is flammable and explosive.

The flammability limits also depend on the temperature $[105,106]$ :

$$
L F L(\mathrm{~T})=L F L\left(25^{\circ} \mathrm{C}\right)-\frac{0.75}{\Delta H}\left(T-25^{\circ} \mathrm{C}\right)
$$




$$
U F L(\mathrm{~T})=U F L\left(25^{\circ} \mathrm{C}\right)+\frac{0.75}{\Delta H}\left(T-25^{\circ} \mathrm{C}\right)
$$

where $L F L(\mathrm{~T})$ and $U F L(\mathrm{~T})$ are the lower and upper flammability limit at a specific temperature, $L F L\left(25^{\circ} \mathrm{C}\right)$ and $\operatorname{UFL}\left(25^{\circ} \mathrm{C}\right)$ the lower and upper flammability limit at $25{ }^{\circ} \mathrm{C}, \Delta H$ the enthalpy of combustion in $\mathrm{kcal} / \mathrm{mol}\left(\right.$ at $\left.25{ }^{\circ} \mathrm{C}\right)$ and $T$ the temperature in ${ }^{\circ} \mathrm{C}$. With $\operatorname{LFL}\left(25^{\circ} \mathrm{C}\right)=5, \operatorname{UFL}\left(25^{\circ} \mathrm{C}\right)=15$ and $\Delta H\left(\mathrm{CH}_{4}\right)=191.8 \mathrm{kcal} / \mathrm{mol}[105], L F L(\mathrm{~T})$ and $U F L(\mathrm{~T})$ were calculated for methane in air and are plotted as a function of temperature in Figure 4.

Figure 4. Lower and upper flammability limits of methane in air at $1 \mathrm{~atm}$ as a function of temperature.

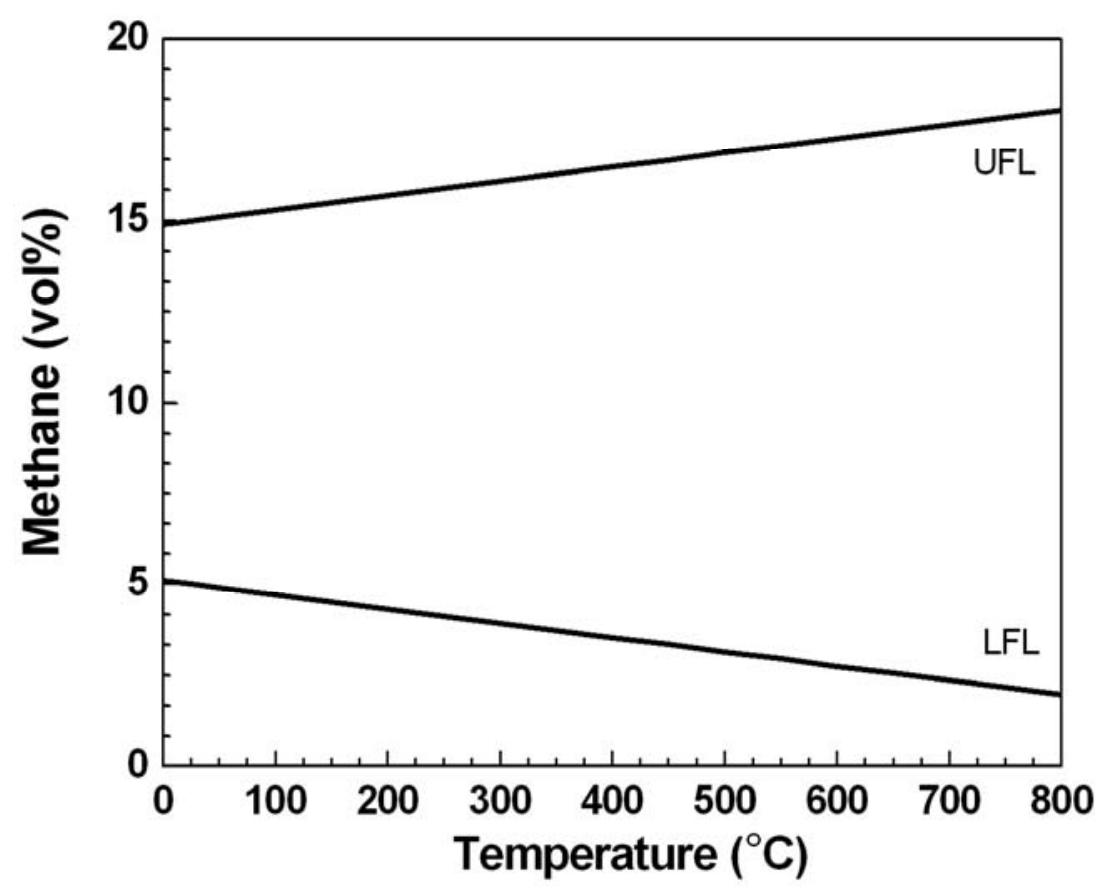

The methane-air mixture used in SC-SOFCs is characterized by the ratio of methane to oxygen, $R_{\text {mix }}$, which can be expressed as a mole, volumetric or flow rate ratio $[5,25,96,103]$ :

$$
R_{\text {mix }}=\frac{\mathrm{CH}_{4}}{\mathrm{O}_{2}}
$$

The critical $R_{\text {mix }}$ corresponding to the lower $\left(R_{\mathrm{mix}, \mathrm{LFL}}\right)$ and upper $\left(R_{\mathrm{mix}, \mathrm{UFL}}\right)$ flammability limit at a certain temperature can be calculated from $L F L(\mathrm{~T})$ and $U F L(T)$, which correspond to the methane concentration in air. For synthetic air composed of oxygen and nitrogen in a ratio of $1: 4, R_{\mathrm{mix}, \mathrm{LFL}}$ and $R_{\text {mix,UFL }}$ can be expressed as:

$$
\begin{aligned}
& R_{\text {mix }, \mathrm{LFL}}(\mathrm{T})=\frac{L F L(\mathrm{~T})}{(100-L F L(\mathrm{~T})) / 5} \\
& R_{\text {mix }, \mathrm{UFL}}(\mathrm{T})=\frac{U F L(\mathrm{~T})}{(100-U F L(\mathrm{~T})) / 5}
\end{aligned}
$$


$R_{\text {mix,LFL }}$ and $R_{\text {mix,UfL }}$ are plotted as a function of temperature in Figure 5 . The region between the two straight lines represents the zone of flammability and $R_{\operatorname{mix}}$ within that zone should be avoided during testing. At $700^{\circ} \mathrm{C}$, the explosive range corresponds to $0.12 \leq R_{\operatorname{mix}} \leq 1.07$.

Figure 5. Critical methane-to-oxygen ratio $R_{\text {mix }}$ as a function of temperature. The area between $R_{\text {mix,LFL }}$ and $R_{\text {mix,UFL }}$ represents the zone of flammability.

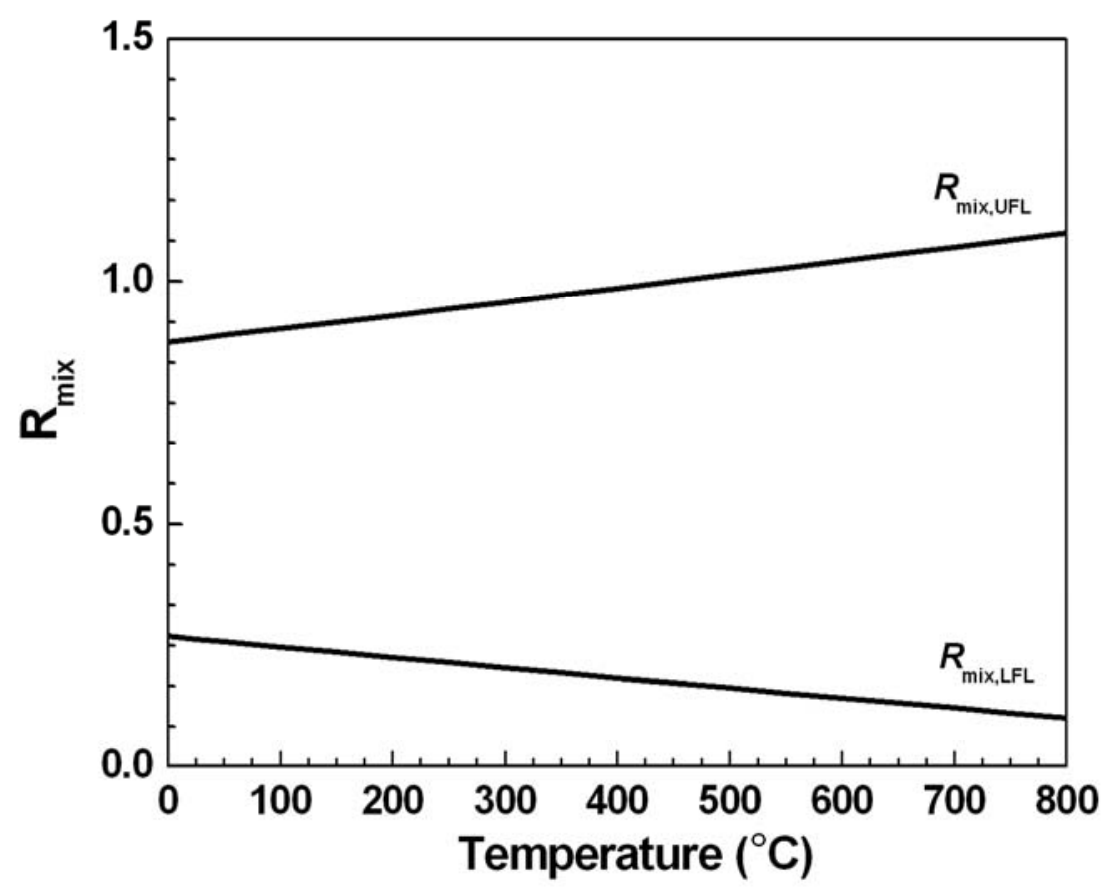

\section{Development of SC-SOFCs}

The principal cell configurations for SC-SOFCs are planar electrolyte-supported cells, planar anode-supported cells, planar fully-porous cells and single-face cells with coplanar electrodes (Figure 6). Planar electrolyte- and anode-supported cells are also used in conventional dual-chamber SOFCs whereas fully-porous and single-face cells are only possible under single-chamber operating conditions. The electrolyte- and anode-supported cells are based on a planar, dual-face cell design where the electrodes are situated on opposite sides of the electrolyte, leading to a three-layer "sandwich" structure (Figure 6a,b). Planar electrolyte-supported cells were the first configuration being investigated for single-chamber operation [48]. However, planar anode-supported SC-SOFCs are gaining increasing interest as they permit the use of a very thin electrolyte on a mechanically supporting anode substrate for reduced ohmic cell resistance at reduced operating temperatures (Figure 6b). Fully-porous SC-SOFCs are also based on the anode-supported cell configuration with the difference that a porous electrolyte is used (Figure 6c) [4]. In single-face SC-SOFCs with coplanar electrodes, both anode and cathode are situated on the same side of the electrolyte (Figure 6d) [107]. Recently, anode-supported SC-SOFCs have also been proposed in a tubular cell configuration [91]. Development, characteristic features and performance of the different cell designs are presented in the following sections. 
Figure 6. Schematics of the principal SC-SOFC cell configurations: (a) planar electrolyte-supported cells, (b) planar anode-supported cells, (c) planar fully-porous cells, (d) cells with coplanar electrodes.

(a)

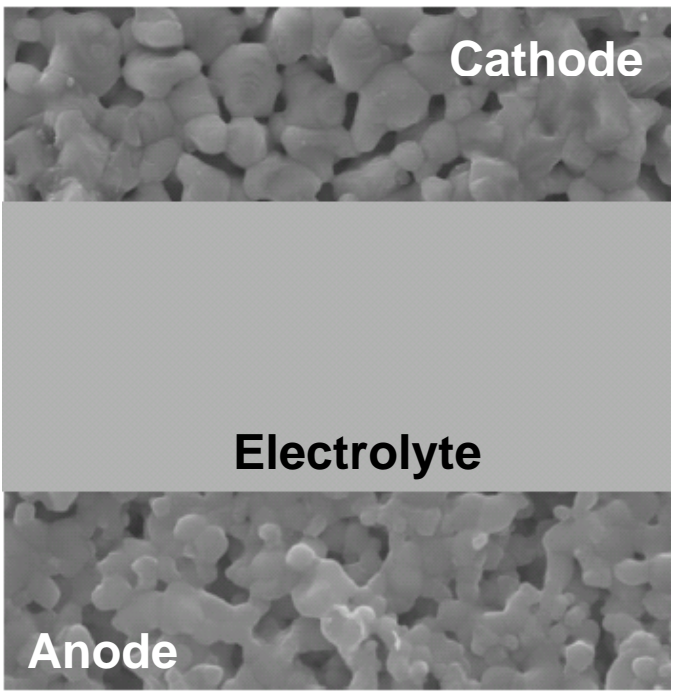

(c)

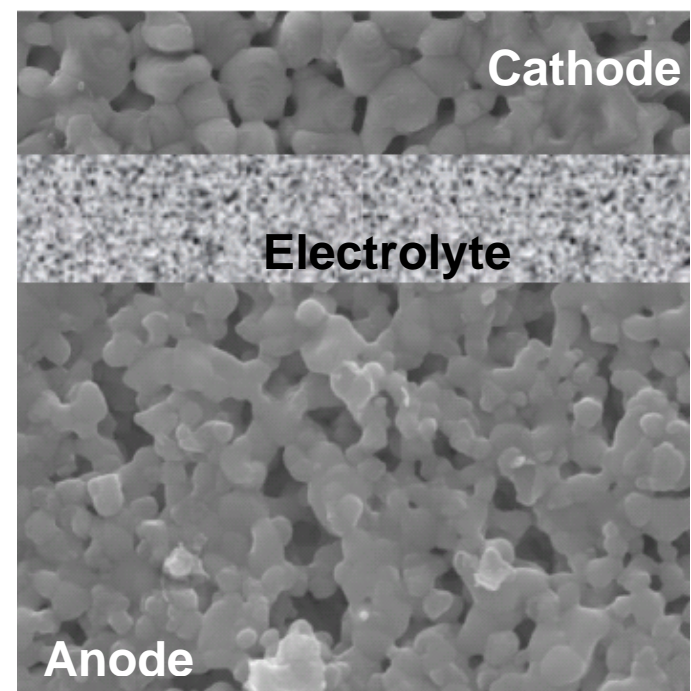

(b)
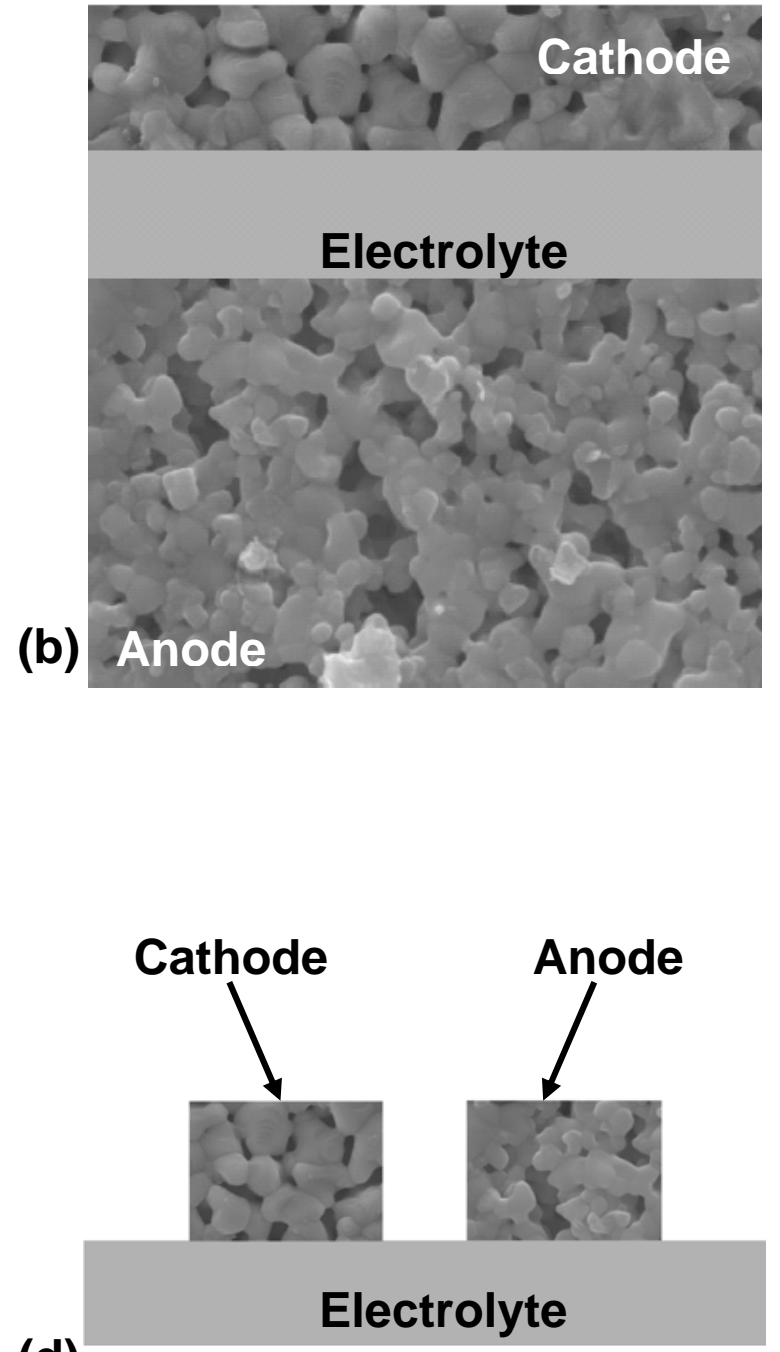

\subsection{Planar electrolyte-supported SC-SOFCs}

5.1.1. Early developments - The work of Hibino et al.

The first SC-SOFC was operated by Hibino et al. [48] in a methane-air mixture $\left(R_{\operatorname{mix}}=2\right)$ at $950{ }^{\circ} \mathrm{C}$ in 1993. The cell, composed of a Ni-YSZ anode, YSZ electrolyte and Au cathode, delivered an OCV of $0.35 \mathrm{~V}$ and a maximum power output of $2.36 \mathrm{~mW} \cdot \mathrm{cm}^{-2}$. By supplying the gas mixture separately to the two electrodes in a dual-chamber configuration for half-cell measurements, it was found that the OCV was due to a local oxygen concentration gradient caused by the catalytic activity of the anode for the partial oxidation of methane. The outlet gas on the cathode side still contained most of the reactants.

In the following year, Hibino et al. [108,109] obtained an OCV of $0.2 \mathrm{~V}$ with a Pt $|\mathrm{YSZ}| \mathrm{Au}$ cell and $0.66 \mathrm{~V}$ with a $\mathrm{Pt}\left|\mathrm{SrCe}_{0.95} \mathrm{Yb}_{0.05} \mathrm{O}_{3-\alpha}\right| \mathrm{Au}$ cell at $950{ }^{\circ} \mathrm{C}$ in a methane-air mixture with $R_{\text {mix }}=2$. 
The cell with the $\mathrm{SrCe}_{0.95} \mathrm{Yb}_{0.05} \mathrm{O}_{3-\alpha}$ electrolyte generated a maximum power density of $21 \mathrm{~mW} \cdot \mathrm{cm}^{-2}$ compared to a hundred times lower power output for the cell with YSZ electrolyte. The mixed conductivity of the $\mathrm{SrCe}_{0.95} \mathrm{Yb}_{0.05} \mathrm{O}_{3-\alpha}$ electrolyte was assumed to lower the cathodic overpotential and thus enable higher cell performance.

The cell performance could be further improved by using a mixed ionic conductor Ba-based electrolyte $[8,68,110]$. An OCV of 0.7 to $0.8 \mathrm{~V}$ was obtained at temperatures between 750 and $950{ }^{\circ} \mathrm{C}$ for a $\mathrm{Pt}\left|\mathrm{BaCe}_{0.8} \mathrm{Y}_{0.2} \mathrm{O}_{3-\alpha}\right| \mathrm{Au}$ cell. The OCV resulted from the difference in catalytic activity for the partial oxidation of methane between the $\mathrm{Pt}$ and $\mathrm{Au}$ electrode. In the methane-air mixture, the $\mathrm{Pt}$ electrode showed a negative potential of -0.8 to $-0.9 \mathrm{~V}$ against a Pt reference electrode and enabled the conversion of up to $50 \%$ of the incoming methane to $\mathrm{H}_{2}$ and $\mathrm{CO}$. The Au electrode was confirmed to be the oxygen reduction electrode as it exhibited an almost zero potential with limited methane conversion. The power density was lowest at $750{ }^{\circ} \mathrm{C}$ with $30 \mathrm{~mW} \cdot \mathrm{cm}^{-2}$ but the peak power density of $170 \mathrm{~mW} \cdot \mathrm{cm}^{-2}$ at $950{ }^{\circ} \mathrm{C}$ was comparable to conventional dual-chamber $\mathrm{Pt}\left|\mathrm{BaCe}_{0.8} \mathrm{Y}_{0.2} \mathrm{O}_{3-\alpha}\right| \mathrm{Au}$ cells. The disadvantage of the Ba-based electrolyte was its instability and affinity for reacting with carbon dioxide to form barium carbonate so that the cell could only be operated during $5 \mathrm{~h}$. Additionally, the gold electrode was unstable due to gold sintering. The use of a $\left(\mathrm{CeO}_{2}\right)_{0.9}\left(\mathrm{SmO}_{1.5}\right)_{0.1}$ electrolyte led to similar low performance as for cells with YSZ electrolyte in combination with Pt and $\mathrm{Au}$ electrodes [8]. A summary of the results with different electrolyte materials, Pt anode and $\mathrm{Au}$ electrode was presented in [111].

Based on the performance enhancement observed when using mixed conductive electrolytes, Hibino and coworkers investigated the performance of SC-SOFCs with doped YSZ electrolytes and Pt and $\mathrm{Au}$ electrodes. The addition of $\mathrm{TiO}_{2}$ [112] reduced the overpotential of the $\mathrm{Au}$ electrode and increased the $\mathrm{OCV}$ at $950{ }^{\circ} \mathrm{C}$ to $0.47 \mathrm{~V}$, compared to $0.2 \mathrm{~V}$ for cells with pure YSZ electrolyte [108]. Doping YSZ with $\mathrm{Tb}_{4} \mathrm{O}_{7}$ even led to an $\mathrm{OCV}$ of $0.55 \mathrm{~V}$, but the cell performance was less stable and reproducible. Coating a thin layer of $\operatorname{Pr}_{6} \mathrm{O}_{11}$ [113] on the cathodic side of the YSZ electrolyte also led to a reduction of the cathode overpotential, and a maximum power output of $15 \mathrm{~mW} \cdot \mathrm{cm}^{-2}$ was obtained at $950{ }^{\circ} \mathrm{C}$ in a methane-air mixture. Coating both sides of the YSZ electrolyte further increased the peak power density to $34 \mathrm{~mW} \cdot \mathrm{cm}^{-2}$, which was 60 times higher than that of the SC-SOFC with an unmodified YSZ electrolyte.

In [114], both $\mathrm{Pt}$ and $\mathrm{Au}$ electrodes were doped with $\mathrm{MnO}_{2}$ leading to a decrease in electrode overpotentials and reaction resistance. For an optimized composition of $15 \mathrm{wt} \% \mathrm{MnO}_{2}-\mathrm{Pt}$ and $20 \mathrm{wt} \%$ $\mathrm{MnO}_{2}$ - $\mathrm{Au}$ on a YSZ electrolyte, an OCV of $0.62 \mathrm{~V}$ and a maximum current density of $160 \mathrm{~mA} \cdot \mathrm{cm}^{-2}$ were obtained whereas the cell with undoped electrodes only delivered $3 \mathrm{~mA} \cdot \mathrm{cm}^{-2}$ in a methane-air mixture $\left(R_{\text {mix }}=2\right)$ at $950{ }^{\circ} \mathrm{C}$. The addition of $\mathrm{MnO}_{2}$ led to thicker, more porous, mixed-conductive electrodes with improved contact to the electrolyte and enhanced the catalytic activity of the electrodes. When the flow rate was increased from 210 to $300 \mathrm{~mL} \cdot \mathrm{min}^{-1}$ and $R_{\text {mix }}=1$ was used, a maximum current density of $240 \mathrm{~mA} \cdot \mathrm{cm}^{-2}$ was obtained. Adding $1 \mathrm{wt} \% \mathrm{MnO}_{2}$ to the $\mathrm{YSZ}$ electrolyte led to $320 \mathrm{~mA} \cdot \mathrm{cm}^{-2}$.

Because the studied SC-SOFCs still showed elevated overpotentials for the Pt and Au electrodes, Hibino et al. started to use conventional SOFC electrode materials. A cell composed of Ni anode and LSM cathode on a YSZ electrolyte led to an OCV close to $0.8 \mathrm{~V}$ at $950{ }^{\circ} \mathrm{C}$ for a methane-to-oxygen ratio of $R_{\text {mix }}=1$, while the Pt $\mid$ YSZ $\mid$ Au cell only delivered an OCV of $0.5 \mathrm{~V}[6,69]$. Additionally, an 
increase in power output from $0.57 \mathrm{~mW} \cdot \mathrm{cm}^{-2}$ to $121 \mathrm{~mW} \cdot \mathrm{cm}^{-2}$ and $150 \mathrm{~mW} \cdot \mathrm{cm}^{-2}$ was achieved by changing from Pt $\mid$ YSZ $\mid \mathrm{Au}$ SC-SOFCs to Ni $\mid$ YSZ $\mid \mathrm{LSM}[6,69]$ and $\mathrm{Ni} \mid \mathrm{La}_{0.9} \mathrm{Sr}_{0.1} \mathrm{Ga}_{0.8} \mathrm{Mg}_{0.2} \mathrm{O}_{3-\alpha}$ (LSGM) | LSM [115], respectively. The improvement was attributed to lower overpotentials for Ni and LSM electrodes and to a higher catalytic activity of nickel for the partial oxidation of methane. Adding $\mathrm{Ce}_{0.8} \mathrm{Gd}_{0.2} \mathrm{O}_{1.9}$ (GDC) to the $\mathrm{Ni}$ anode and $\mathrm{MnO}_{2}$ to the $\mathrm{LSM}$ cathode further enhanced the cell performance by increasing the catalytic activity of nickel and reducing the activity of LSM $[6,69,116]$. At $950{ }^{\circ} \mathrm{C}$ in a methane-air mixture with $R_{\text {mix }}=1$, the Ni-GDC $\mid$ YSZ $\mid$ LSM-MnO 2 cell delivered a peak power density of $161 \mathrm{~mW} \cdot \mathrm{cm}^{-2}$ which was very close to the performance of the $\mathrm{Pt}\left|\mathrm{BaCe}_{0.8} \mathrm{Y}_{0.2} \mathrm{O}_{3-\alpha}\right| \mathrm{Au}$ cell $[68,110]$. A maximum power output of $204 \mathrm{~mW} \cdot \mathrm{cm}^{-2}$ was finally obtained by decreasing the electrolyte thickness and therefore the ohmic cell resistance [69].

The performance of the Ni-GDC |YSZ | LSM- $-\mathrm{MnO}_{2}$ cells was further improved by applying a thin layer of $\mathrm{MnO}_{2}$ on the YSZ electrolyte surface [117]. The metal layer effectively reduced the electrode overpotentials and polarization resistance, and enhanced the anodic and cathodic reactions. With the optimized operating parameters (flow rate, $R_{\text {mix }}$, temperature), a decrease in electrolyte thickness from $0.6 \mathrm{~mm}$ to $0.3 \mathrm{~mm}$ led to a maximum power density of $256 \mathrm{~mW} \cdot \mathrm{cm}^{-2}$. Carbon deposition on the anode as observed after testing could be impeded by using methane-air mixtures saturated with water vapor.

\subsubsection{Confirmation of the feasibility of SC-SOFCs}

Bay et al. [7] were the first group trying to reproduce the results obtained by Hibino et al. However, for a $\mathrm{Pt}$ anode and $\mathrm{Au}$ cathode at $950{ }^{\circ} \mathrm{C}$ in a methane-air mixture $\left(R_{\text {mix }}=2\right)$, very low performance was obtained on various electrolytes, the highest power density being only $4 \mathrm{~mW} \cdot \mathrm{cm}^{-2}$.

A confirmation of the results by Hibino et al. was provided for SC-SOFCs constructed from conventional SOFC materials. In 2000, Demin et al. [82] measured OCVs between 0.7 and $0.9 \mathrm{~V}$ when testing a Ni-YSZ $\left|\left(\mathrm{Y}_{2} \mathrm{O}_{3}\right)_{0.04}\left(\mathrm{Sc}_{2} \mathrm{O}_{3}\right)_{0.06}\left(\mathrm{ZrO}_{2}\right)_{0.9}\right| \mathrm{LSM}$ cell in a methane-air mixture. The peak power density was however only about $8.5 \mathrm{~mW} \cdot \mathrm{cm}^{-2}$. For a Ni-YSZ |YSZ | LSM cell tested at $800^{\circ} \mathrm{C}$, power densities of $85 \mathrm{~mW} \cdot \mathrm{cm}^{-2}$ were obtained by Napporn et al. [26, 27]. At an operating temperature closer to the one reported by Hibino et al., at $900{ }^{\circ} \mathrm{C}$, cell degradation and reaction between nickel and the gold current collector mesh led however to poor cell performance.

Buergler et al. also confirmed the work of Hibino et al. by reproducing the high OCVs and power densities [99-101]. An electrolyte-supported SC-SOFC with Ni-CGO anode and SSC cathode on a CGO electrolyte delivered an OCV of $0.68 \mathrm{~V}$ and a peak power density of $468 \mathrm{~mW} \cdot \mathrm{cm}^{-2}$ at $600{ }^{\circ} \mathrm{C}$. At $500{ }^{\circ} \mathrm{C}$, an $\mathrm{OCV}$ of about $0.8 \mathrm{~V}$ was reached, but the power output was only $250 \mathrm{~mW} \cdot \mathrm{cm}^{-2}$.

The following sections present the further development of electrolyte-supported SC-SOFCs with respect to materials, operating conditions and cell stacks.

\subsubsection{Materials}

\section{Anode materials}

Comparison between different anode materials, such as $\mathrm{Ni}-\mathrm{SDC}, \mathrm{Ni}, \mathrm{Pd}$ and $\mathrm{Pt}$, revealed that Ni-SDC possessed the highest catalytic activity for the partial oxidation of methane for tests 
effectuated at $700{ }^{\circ} \mathrm{C}$ [55]. After optimizing the choice of the cathode and electrolyte material, an OCV close to $0.9 \mathrm{~V}$ for temperatures between 600 and $800{ }^{\circ} \mathrm{C}$ and a maximum power output of $450 \mathrm{~mW} \cdot \mathrm{cm}^{-2}$ at the latter temperature were measured in a methane-air mixture. The performance decrease occurring at $900{ }^{\circ} \mathrm{C}$ was attributed to the increasing catalytic activity of the cathode for fuel conversion, whereas no power output was obtained at temperatures below $600{ }^{\circ} \mathrm{C}$ with the reactivity of methane being too low to sustain its partial oxidation.

Ni-YSZ, Ni-CGO and $\mathrm{Ni}-\mathrm{Sm}_{0.2} \mathrm{Ce}_{0.8} \mathrm{O}$ (CSO) anodes were compared by electrochemical performance tests and means of impedance spectroscopy [118]. Cells with Ni-YSZ anode showed an improved stability of the OCV over the tested temperature range $\left(500\right.$ to $\left.640{ }^{\circ} \mathrm{C}\right)$. Due to its higher catalytic activity, the use of the Ni-YSZ anode also enabled the highest OCV at temperatures below $550{ }^{\circ} \mathrm{C}$. However, because of a larger particle size, the Ni-YSZ anode exhibited a larger resistance which was comparable to the sum of cathode and electrolyte resistance.

Replacing a simple $\mathrm{Ni}$ anode by a mixed conductive $\mathrm{NiO}-\mathrm{ZrO}_{2}-\mathrm{CeO}_{2}$ anode enabled an increase in performance by $36 \%$ in a methane-air mixture at $950{ }^{\circ} \mathrm{C}$ [119]. $\mathrm{H}_{2}$ and $\mathrm{CO}$ were found to be formed from the complete oxidation products $\mathrm{H}_{2} \mathrm{O}$ and $\mathrm{CO}_{2}$ at the elevated operating temperature. In a following study [120], $\mathrm{Ni}-\mathrm{Ce}_{0.9} \mathrm{Zr}_{0.1} \mathrm{O}_{2}$ catalyst anodes were shown to be active for complete methane oxidation at low temperatures, but to mainly produce $\mathrm{H}_{2}$ and $\mathrm{CO}$ at temperatures above $550{ }^{\circ} \mathrm{C}$.

Because of low cell performance with methane as fuel at temperatures below $600{ }^{\circ} \mathrm{C}$ [52], different compositions of Ni-based anodes were investigated to enhance the partial oxidation of methane [80]. The addition of PdO to the Ni-SDC anode led to an increase of the OCV from only 0.11 to $0.91 \mathrm{~V}$ at $550{ }^{\circ} \mathrm{C}$. Analysis of the outlet gases and methane conversion confirmed that the formation of $\mathrm{H}_{2}$ and $\mathrm{CO}$ via partial oxidation of methane was significantly enhanced and fast over the Pd containing anode. The use of $\mathrm{Pd}$ as an additive in the Ni-SDC anode permitted achieving comparable power outputs in methane-air mixtures at reduced temperature compared to ethane and propane fuels. Similarly, Pd-Ni-SDC composite anodes for intermediate operating temperatures were studied in $[81,121]$. Doping Ni-CGO anodes with small amounts of Pd was also found to be beneficial especially at low air flows (elevated $R_{\text {mix }}$ ) [99-101], whereas the addition of a small amount of $\mathrm{Ru}$ to porous $\mathrm{NiO}$ films on GDC electrolyte substrates significantly impeded the reoxidation of the nickel anode in a methane-air gas mixture [122]. In [82], ceria was added to a Ni-YSZ anode in order to increase the catalytic activity of the electrode for the partial oxidation of methane at temperatures below $750{ }^{\circ} \mathrm{C}$. A $\mathrm{Ni}-\mathrm{CaZr}_{0.9} \mathrm{In}_{0.1} \mathrm{O}_{3-\alpha}(\mathrm{Ni}-\mathrm{CZI10})$ composite electrode worked as anode in a single-chamber fuel cell used for methane detection [123].

In addition to composition, the microstructure of the Ni-YSZ anode was also found to affect cell performance [124]. Although a cell with a thin, nanoporous Ni-YSZ anode showed a lower power output than a cell with a conventional, thick, micro-porous anode, the peak power density was highest for a cell with multilayer, nanoporous Ni-YSZ. A nanoporous anode might exhibit an increased TPB length and electrochemical activity, but a certain thickness is necessary to provide sufficient electrical conductance.

\section{Cathode materials}

LSM is one of the common cathode materials used in SC-SOFCs. However, its catalytic activity and selectivity were found to depend on sintering and cell operating temperature $[53,57,125]$. 
Cathode sintering temperatures of 1,000 to $1,050{ }^{\circ} \mathrm{C}$ together with furnace temperatures between 550 and $600{ }^{\circ} \mathrm{C}$ led to the highest power densities in propane-air mixtures [53,125]. LSM sintered at lower temperatures was assumed to show higher catalytic activity for the endothermic propane reforming reaction, thus decreasing cell temperature and performance. Similar observations were made for cells with LSM cathodes operated in methane-air mixtures [57]. The LSM cathode sintered at $1,100{ }^{\circ} \mathrm{C}$ showed a higher catalytic activity for methane conversion than the cathode sintered at $1,200{ }^{\circ} \mathrm{C}$. The catalytic activity was also dependent on the operating temperature.

In addition to LSM, SSC and LSCF are being considered as cathode materials for SC-SOFCs. In a comparative study [125], cells with LSM cathodes showed the lowest peak power density in propane-air mixtures whereas the use of LSCF enabled the best cell performance. Compared to LSM cathodes, an inverse effect of cathode sintering temperature on the power output was observed for cells with SSC. Sintering SSC at temperatures above $900{ }^{\circ} \mathrm{C}$ led to reduced cell performance due to electrode shrinkage and interactions with the electrolyte. Additionally, SSC showed increasing activity for methane [55] and propane [52] oxidation reactions with increasing operating temperature, leading to a drop of the measured electrical performance. Nonetheless, SSC cathodes exhibited lower resistance and enabled higher power outputs than $\mathrm{La}_{0.6} \mathrm{Sr}_{0.4} \mathrm{CoO}_{3}, \mathrm{LaNi}_{0.6} \mathrm{Fe}_{0.4} \mathrm{O}_{3}$ or LSM cathode materials in methane-air mixtures [55]. LSCF cathodes were found to be less affected by the sintering temperature [125] and the addition of $10 \%$ SDC to the cathode was shown to reduce the catalytic activity of LSCF for propane oxidation [126-128]. Moreover, high oxygen conductivity of the mixed conductive LSCF cathodes led to reduced interfacial resistances with the electrolyte as the oxygen ion conduction allowed surface reactions and dissolution of oxygen into the cathode and enhanced transport of oxygen ions to the cathode/electrolyte interface [129]. Using a Ni-YDC $\left(\mathrm{Ce}_{0.85} \mathrm{Y}_{0.15} \mathrm{O}_{1.925}\right)$ anode which was active for the methane partial oxidation, and a SDC electrolyte, an OCV of $0.7 \mathrm{~V}$ and a maximum power density of $186 \mathrm{~mW} \cdot \mathrm{cm}^{-2}$ were obtained at $800{ }^{\circ} \mathrm{C}$ in a methane-air mixture $\left(R_{\text {mix }}=1\right)$. In contrast, a cell with LSM cathode only led to $0.46 \mathrm{~V}$ and $30 \mathrm{~mW} \cdot \mathrm{cm}^{-2}$. LSCF was also proposed in [130-132] as suitable cathode material with high activity for the oxygen reduction. Mixed conductivity and an elevated specific surface area of the fabricated nanocrystalline cathode powder were beneficial for lowering polarization losses at the electrode-electrolyte interface.

New cathode materials were also proposed such as mixed-conductive $\mathrm{Ln}_{0.7} \mathrm{Sr}_{0.3} \mathrm{Fe}_{0.8} \mathrm{Co}_{0.2} \mathrm{O}_{3-\delta}$ ( $\mathrm{Ln}=\mathrm{Pr}, \mathrm{La}, \mathrm{Gd})$ [133] and $\mathrm{Nd}_{1.95} \mathrm{NiO}_{4+\delta}$ with presumably improved oxygen conductivity and electrocatalytic activity as compared to perovskite-type cathode materials [134]. $\mathrm{La}_{0.5} \mathrm{Sr}_{0.5} \mathrm{CoO}_{3}$ (LSCO) was investigated for stable operation in propane-air mixtures at temperatures up to $650{ }^{\circ} \mathrm{C}[135]$ and in methane-air mixtures at temperatures below $800{ }^{\circ} \mathrm{C}$ [136].

\section{Electrolyte materials}

Hibino et al. [52,55,137] compared LSGM, SDC and YSZ electrolyte materials for operation in different fuel-air mixtures. The use of a LSGM electrolyte in combination with a Ni-SDC anode and a SSC cathode led to the highest OCV and power density in methane-air mixtures from 600 to $800{ }^{\circ} \mathrm{C}$ [55]. During operation in ethane-air mixtures at lower temperatures $\left(500{ }^{\circ} \mathrm{C}\right)$, an OCV of $0.9 \mathrm{~V}$ was obtained in the case of all three electrolyte materials [52]. However, cells with SDC electrolyte showed lower ohmic resistance and higher current densities than cells with LSGM and YSZ [52,137]. Additionally, the reduction of electrolyte thickness for low temperature operation was more effective 
for SDC [52] than LSGM [55]. In combination with Ni-SDC anode and SSC cathode, reducing the thickness of a SDC electrolyte from $0.5 \mathrm{~mm}$ to $0.15 \mathrm{~mm}$ led to an increase in power density from 140 to $400 \mathrm{~mW} \cdot \mathrm{cm}^{-2}$ as compared to an increase from 163 to $270 \mathrm{~mW} \cdot \mathrm{cm}^{-2}$ for LSGM (thickness of 0.5 to $0.18 \mathrm{~mm}$ ) at $500-550{ }^{\circ} \mathrm{C}$ in ethane-air mixtures. SDC was revealed as most promising electrolyte material for low temperature operation in ethane- and propane-air mixtures at temperatures between 350 and $450{ }^{\circ} \mathrm{C}[52]$.

New barium-based electrolyte materials were studied in an attempt to improve cell performance [138]. Compared to YSZ electrolytes with a power output of only $5 \mathrm{~mW} \cdot \mathrm{cm}^{-2}$, the higher conductivity of the $\mathrm{BaLaIn} \mathrm{O}_{5.5}$ electrolyte enabled a peak power density of about $40 \mathrm{~mW} \cdot \mathrm{cm}^{-2}$. By increasing the sintering temperatures of the SSC cathode and NiO- $\left(\mathrm{La}_{0.75} \mathrm{Sr}_{0.25}\right)_{0.9} \mathrm{Cr}_{0.5} \mathrm{Mn}_{0.5} \mathrm{O}_{3}(\mathrm{LSCM})$ anode, the power output could be further increased.

A proton-conducting $\mathrm{CaZr}_{0.9} \mathrm{In}_{0.1} \mathrm{O}_{3-\alpha}(\mathrm{CZI10})$ electrolyte was used in a single-chamber fuel cell working as a catalytic methane sensor [123].

\subsubsection{Effect of testing conditions}

Based on observations by Bay et al. [7] on cell performance and testing chamber configuration, Stefan et al. [97] studied the effect of chamber design, gas flow direction, gas flow rate and gas composition for a Ni-SDC | SDC | SSC cell in propane-air mixtures at $600{ }^{\circ} \mathrm{C}$. In a closed chamber, gas intermixing disturbed the establishment of a stable oxygen partial pressure difference between anode and cathode and therefore the OCV. Using flow rates over $300 \mathrm{~mL} \cdot \mathrm{min}^{-1}$ and oxygen-rich gas mixtures helped to maintain a sufficiently high oxygen concentration gradient, but performance was lower as compared to an open chamber design. In the open chamber design, cells with electrodes arranged parallel to the gas flow direction generated the highest power density $\left(18 \mathrm{~mW} \cdot \mathrm{cm}^{-2}\right)$ for high gas flows whereas under lower flow rates orienting the cell with the cathode being exposed first to the incoming gases was more favorable. Highest $\mathrm{OCV}$ and maximum power were obtained for oxygen-rich gas mixtures $\left(R_{\operatorname{mix}}=0.56\right)$.

The effect of anode thickness, gas flow rate [139] and operating temperature [99-101] on cell performance was investigated by Buergler et al. Ni-CGO anodes with a thickness of $60 \mu \mathrm{m}$ delivered the highest OCV and power output in methane-air mixtures whereas very thin anodes $(9 \mu \mathrm{m})$ led to unstable cell performance [139]. Oscillations of the OCV were attributed to oxidation-reduction cycles of the Ni-cermet and accompanying temperature fluctuations. Gas flow rates over $250 \mathrm{~mL} \cdot \mathrm{min}^{-1}$ induced an elevated amount of oxygen to the anode side and destabilized the oxygen partial pressure leading to a low OCV. However, higher gas flow caused an increase of the anode temperature and therefore enhanced catalytic activity of the anode. At flow rates below $70 \mathrm{~mL} \cdot \mathrm{min}^{-1}$, the amount of gas reaching the electrode/electrolyte interface was too little to establish the required oxygen partial pressure and to promote sufficient reaction rates. The effect of temperature on the OCV was observed by monitoring the OCV during heating and cooling [99-101]. As the furnace temperature exceeded $500{ }^{\circ} \mathrm{C}$, the $\mathrm{OCV}$ abruptly increased from $0.1 \mathrm{~V}$ to $0.96 \mathrm{~V}$ due to the reduction of $\mathrm{NiO}$ to $\mathrm{Ni}$ and the accompanying heat release. Increasing the temperature further led to a voltage decrease. During cool-down of the cell, a minimum temperature of $400{ }^{\circ} \mathrm{C}$ was identified for low temperature operation. 
The existence of an upper limit of the operating temperature for cells with conventional LSM-based cathodes was identified by Napporn et al. [57]. Elevated temperatures led to enhanced oxygen conversion on LSM cathodes with the accompanying oxygen depletion significantly affecting cell voltage and power output. In order to counterbalance the catalytic activity of LSM for $\mathrm{CH}_{4}$ and $\mathrm{O}_{2}$ conversion, an upper operation temperature limit should be respected. This limit can be shifted to higher temperatures by increasing the sintering temperature and therefore reducing the catalytic activity of the cathode.

\subsubsection{Reduction of the operating temperature}

At the beginning of SC-SOFC technology, operating temperatures in the range of 700 to $950{ }^{\circ} \mathrm{C}$ were used. However, as a major drawback of SOFCs, elevated operating temperatures enhance material and cell performance degradation and reduce the long-term stability of the fuel cells. In conventional SOFCs, reduction of the operating temperature can be achieved by selecting suitable electrolyte materials and reducing the electrolyte thickness. The following additional parameters were pointed out for the successful low temperature operation of SC-SOFCs [5]: (i) the use of higher, more reactive hydrocarbons, (ii) improved catalytic activity of anodes by addition of noble metals and (iii) the use of the heat release during hydrocarbon oxidation which increases cell temperature and reduces cell resistance.

At temperatures around $550{ }^{\circ} \mathrm{C}$, higher hydrocarbons such as ethane, propane, liquefied petroleum gas (LPG) and ethanol enabled significantly higher cell performance as compared to methane [55]. Best performance was obtained with ethane as fuel which allowed operation in a temperature range of 350 to $700{ }^{\circ} \mathrm{C}$.

With addition of $\mathrm{PdO}$ to $\mathrm{Ni}-\mathrm{SDC}$ anodes, low temperature operation with methane could be improved [80]. Increasing the electrode surface area and reduction of the electrolyte thickness ( 0.5 to $0.15 \mathrm{~mm})$ additionally enhanced the cell performance due to the reduction of electrode-reaction resistance and ohmic resistance, respectively. The optimized cell delivered a peak power density of $644 \mathrm{~mW} \cdot \mathrm{cm}^{-2}$ for $R_{\text {mix }}=1$ at $550{ }^{\circ} \mathrm{C}$. Reduction of the operating temperature to $450{ }^{\circ} \mathrm{C}$ decreased the peak power density to $269 \mathrm{~mW} \cdot \mathrm{cm}^{-2}$.

Operating temperatures of 300 to $450{ }^{\circ} \mathrm{C}$ became possible due to the use of the heat release from the partial oxidation of the hydrocarbon fuel as internal heat source [93]. For a Ni-SDC |SDC |SSC system with optimized electrode composition, electrode surface area and electrolyte thickness, the exothermic partial oxidation of the fuel led to electrode temperatures of up to $150{ }^{\circ} \mathrm{C}$ higher than the furnace temperature. This heat release worked as an internal heat source and enabled cell operation even at low furnace temperatures of only $300{ }^{\circ} \mathrm{C}$. Higher hydrocarbons such as butane and its branched form isobutane, which caused the greatest enthalpy change during partial oxidation among the studied hydrocarbon fuels, gave the highest power output. Partial oxidation of hydrocarbons with short chain length and low $\mathrm{H} / \mathrm{C}$ ratios, such as methane and butene, did not generate enough heat to allow cell operation. At temperatures below $600{ }^{\circ} \mathrm{C}$, the reactivity of methane was too low to sustain its partial oxidation and no power output could be obtained [55]. 


\subsubsection{Cell initialization}

Ni-based anodes are generally fabricated from $\mathrm{NiO}$ as a starting material which needs to be reduced to $\mathrm{Ni}$ prior to cell operation. The reduction process of NiO-CGO anodes in methane-air mixtures was studied by Buergler et al. [4]. The reduction temperature was found to depend on the gas mixing ratio and to decrease for methane-rich gas mixtures. The addition of catalyst metals such as Pd or Pt also significantly reduced the reduction temperature to less than $600{ }^{\circ} \mathrm{C}$. The reduced anode showed a higher catalytic activity for the partial oxidation of methane than the unreduced electrode.

The reduction process of NiO-YSZ anodes was investigated by Napporn et al. [140]. The amount of formed $\mathrm{CO}, \mathrm{CO}_{2}$ and $\mathrm{H}_{2}$ as well as the evolution of cell temperature and potential were used to follow the reduction progress.

\subsubsection{Cell stacks}

The first demonstration of assembling and operating SC-SOFCs in stacks was provided by Goedickemeier at al. [16]. Several single cells were combined in serial connection on the same electrolyte. An OCV of $0.8 \mathrm{~V}$ and a peak power density of about $6 \mathrm{~mW} \cdot \mathrm{cm}^{-2}$ were measured at $700{ }^{\circ} \mathrm{C}$ in a methane-air mixture with a single cell of $\mathrm{Pt}|\mathrm{YSZ}| \mathrm{Au}$ whereas $3 \mathrm{~V}$ in open circuit were obtained from the series connection.

Suzuki et al. $[127,141]$ used the simplified design of SC-SOFCs to fabricate and test a SC-SOFC electrolyte-supported miniature cell module. The cells consisted of Ni-SDC anode and LSCF-SDC cathode on a $0.5 \mathrm{~mm}$ thick SDC electrolyte and were tested between 500 and $575{ }^{\circ} \mathrm{C}$ in a propane-air mixture $\left(R_{\text {mix }}=0.56\right)$. A single cell $\left(3 \times 6 \mathrm{~mm}^{2}\right.$ electrode area) delivered an OCV of $0.8 \mathrm{~V}$. The lowest electrolyte resistance was measured at $575{ }^{\circ} \mathrm{C}$, enabling a maximum power of $20 \mathrm{~mW}$. A two-cell stack (module A with $2 \times 2 \mathrm{~mm}^{2}$ electrode area, module B with $3 \times 3 \mathrm{~mm}^{2}$ electrode area) was fabricated by applying two anodes on one side and two cathodes on the other side of the electrolyte. The two single cells were connected in series using gold as interconnector and delivered OCVs of 1.48 and $1.6 \mathrm{~V}$ at $500{ }^{\circ} \mathrm{C}$, respectively. At $575{ }^{\circ} \mathrm{C}$, the $\mathrm{OCV}$ was reduced to $1.2 \mathrm{~V}$ and $1.35 \mathrm{~V}$. The maximum power obtained with module $\mathrm{A}$ was $4.5 \mathrm{~mW}$ at $575{ }^{\circ} \mathrm{C}$, whereas module $\mathrm{B}$ delivered approximately the same power as the single cell of the same electrode surface. A 20 cell stack based on module $\mathrm{B}$ was estimated to deliver $15 \mathrm{~V}$ and $0.18 \mathrm{~W}$.

\subsubsection{Summary of planar electrolyte-supported SC-SOFCs}

The development, progress and performance of planar electrolyte-supported SC-SOFCs reported in the literature are summarized in Table 2. If cell performance was measured under different testing conditions, the highest cell performance and corresponding testing parameters reported in the reference are listed in the following table. Results for different cell component materials are also presented. 
Table 2. Summary of planar electrolyte-supported SC-SOFCs.

\begin{tabular}{|c|c|c|c|c|c|c|c|c|c|}
\hline Reference & Year & Electrolyte & $\begin{array}{c}\text { Electrolyte } \\
\text { thickness }(\mathrm{mm})\end{array}$ & Anode & Cathode & $\begin{array}{c}\text { Gas } \\
\text { mixture }\end{array}$ & $\begin{array}{l}T_{\text {furnace }} \\
\left({ }^{\circ} \mathrm{C}\right)\end{array}$ & $\begin{array}{c}\text { OCV } \\
\text { (V) }\end{array}$ & $\underset{\left(\mathbf{m W} \cdot \mathbf{c m}^{-2}\right)}{\boldsymbol{P}_{\max }}$ \\
\hline$[48]$ & 1993 & YSZ & 0.5 & Ni-YSZ & $\mathrm{Au}$ & $\begin{array}{l}\mathrm{CH}_{4} \text {-air } \\
R_{\text {mix }}=2\end{array}$ & 950 & 0.35 & 2.36 \\
\hline \multirow{2}{*}{$\begin{array}{c}{[108,109] /} \\
{[8] /[111]}\end{array}$} & \multirow{2}{*}{$\begin{array}{c}1994 / \\
1995 / 1998\end{array}$} & YSZ & \multirow{2}{*}{0.5} & \multirow{2}{*}{$\mathrm{Pt}$} & \multirow{2}{*}{$\mathrm{Au}$} & \multirow{2}{*}{$\begin{array}{l}\mathrm{CH}_{4} \text {-air } \\
R_{\text {mix }}=2\end{array}$} & \multirow{2}{*}{950} & 0.2 & 0.2 \\
\hline & & $\mathrm{SrCe}_{0.95} \mathrm{Yb}_{0.05} \mathrm{O}_{3-\alpha}$ & & & & & & 0.66 & 21 \\
\hline $\begin{array}{c}{[8,68,110] /} \\
{[111]}\end{array}$ & 1995/1998 & $\mathrm{BaCe}_{0.8} \mathrm{Y}_{0.2} \mathrm{O}_{3-\alpha}$ & 0.5 & $\mathrm{Pt}$ & $\mathrm{Au}$ & $\begin{array}{l}\mathrm{CH}_{4} \text {-air } \\
R_{\text {mix }}=2\end{array}$ & 950 & 0.77 & 170 \\
\hline$[8] /[111]$ & $1995 / 1998$ & $\left(\mathrm{CeO}_{2}\right)_{0.9}\left(\mathrm{SmO}_{1.5}\right)_{0.1}$ & 0.5 & $\mathrm{Pt}$ & $\mathrm{Au}$ & $\begin{array}{l}\mathrm{CH}_{4} \text {-air } \\
R_{\text {mix }}=2\end{array}$ & 950 & 0.3 & \\
\hline [112] & 1996 & $\mathrm{TiO}_{2}$-doped YSZ & 0.5 & $\mathrm{Pt}$ & $\mathrm{Au}$ & $\begin{array}{l}\mathrm{CH}_{4} \text {-air } \\
R_{\text {mix }}=2 \\
\end{array}$ & 950 & 0.47 & 3 \\
\hline [113] & 1997 & $\operatorname{Pr}_{6} \mathrm{O}_{11}$-doped YSZ & 0.5 & $\mathrm{Pt}$ & $\mathrm{Au}$ & $\begin{array}{l}\mathrm{CH}_{4} \text {-air } \\
R_{\text {mix }}=2\end{array}$ & 950 & 0.7 & 34 \\
\hline$[16]$ & 1997 & YSZ & 0.06 & $\mathrm{Pt}$ & $\mathrm{Au}$ & $\mathrm{CH}_{4}$-air & 700 & 0.8 & 6 \\
\hline \multirow{4}{*}[7]{} & \multirow{4}{*}{1998} & YSZ & & \multirow{4}{*}{$\mathrm{Pt}$} & \multirow{4}{*}{$\mathrm{Au}$} & \multirow{4}{*}{$\begin{array}{l}\mathrm{CH}_{4} \text {-air } \\
R_{\text {mix }}=2\end{array}$} & \multirow{4}{*}{950} & & 0.2 \\
\hline & & Pr-doped YSZ & & & & & & & $2.5-3$ \\
\hline & & Pr-coated YSZ & & & & & & & 2.4 \\
\hline & & $\mathrm{SrCe}_{0.95} \mathrm{Y}_{0.05} \mathrm{O}_{3-\alpha}$ & & & & & & & 4 \\
\hline \multirow{2}{*}[114]{} & \multirow{2}{*}{1999} & YSZ & \multirow{2}{*}{0.5} & \multirow{2}{*}{$\mathrm{Pt}-\mathrm{MnO}_{2}$} & \multirow{2}{*}{$\mathrm{Au}-\mathrm{MnO}_{2}$} & \multirow{2}{*}{$\begin{array}{l}\mathrm{CH}_{4} \text {-air } \\
R_{\text {mix }}=1\end{array}$} & \multirow{2}{*}{950} & \multirow{2}{*}{0.6} & 48 \\
\hline & & $\mathrm{MnO}_{2}$-doped YSZ & & & & & & & 52 \\
\hline \multirow{3}{*}[6]{} & \multirow{3}{*}{1999} & \multirow{3}{*}{ YSZ } & \multirow{3}{*}{0.5} & $\mathrm{Pt}$ & $\mathrm{Au}$ & \multirow{3}{*}{$\begin{array}{l}\mathrm{CH}_{4} \text {-air } \\
R_{\text {mix }}=1\end{array}$} & \multirow{3}{*}{950} & 0.5 & 0.57 \\
\hline & & & & $\mathrm{Ni}$ & LSM & & & 0.8 & 121 \\
\hline & & & & Ni-GDC & $\mathrm{LSM} \mathrm{MnO}_{2}$ & & & 0.83 & 162 \\
\hline
\end{tabular}


Table 2. Cont.

\begin{tabular}{|c|c|c|c|c|c|c|c|c|c|}
\hline Reference & Year & Electrolyte & $\begin{array}{c}\text { Electrolyte } \\
\text { thickness }(\mathbf{m m})\end{array}$ & Anode & Cathode & $\begin{array}{c}\text { Gas } \\
\text { mixture }\end{array}$ & $\begin{array}{c}T_{\text {furnace }} \\
\left({ }^{\circ} \mathrm{C}\right)\end{array}$ & $\begin{array}{c}\text { OCV } \\
(\mathrm{V})\end{array}$ & $\underset{\left(\mathbf{m W} \cdot \mathbf{c m}^{-2}\right)}{\boldsymbol{P}_{\max }}$ \\
\hline [115] & 1999 & LSGM & 0.5 & $\mathrm{Ni}$ & LSM & $\begin{array}{l}\mathrm{CH}_{4} \text {-air } \\
R_{\text {mix }}=1\end{array}$ & 950 & 0.8 & 150 \\
\hline$[69]$ & 2000 & YSZ & 0.3 & Ni-GDC & LSM-MnO ${ }_{2}$ & $\begin{array}{l}\mathrm{CH}_{4} \text {-air } \\
R_{\text {mix }}=1\end{array}$ & 950 & 0.8 & 204 \\
\hline \multirow{3}{*}[52]{} & \multirow{3}{*}{2000} & SDC & 0.15 & \multirow{3}{*}{ Ni-SDC } & \multirow{3}{*}{$\mathrm{SSC}$} & \multirow{3}{*}{$\begin{array}{c}\mathrm{C}_{2} \mathrm{H}_{6} \text {-air } \\
R_{\mathrm{mix}}=1\end{array}$} & \multirow{3}{*}{500} & \multirow{3}{*}{0.9} & 400 \\
\hline & & LSGM & 05 & & & & & & \\
\hline & & YSZ & & & & & & & \\
\hline$[117]$ & 2000 & $\mathrm{MnO}_{2}$-doped YSZ & 0.3 & Ni-GDC & LSM-MnO & $\begin{array}{l}\mathrm{CH}_{4} \text {-air } \\
R_{\text {mix }}=1\end{array}$ & 950 & 0.8 & 256 \\
\hline \multirow{3}{*}[55]{} & \multirow{3}{*}{2000} & LSGM & \multirow{3}{*}{0.5} & \multirow{3}{*}{ Ni-SDC } & \multirow{3}{*}{$\mathrm{SSC}$} & \multirow{3}{*}{$\begin{array}{l}\mathrm{CH}_{4} \text {-air } \\
R_{\text {mix }}=1\end{array}$} & 800 & 0.9 & 450 \\
\hline & & YSZ & & & & & \multirow{2}{*}{700} & 0.9 & 125 \\
\hline & & SDC & & & & & & 0.72 & 150 \\
\hline$[82]$ & 2000 & $\begin{array}{c}\left(\mathrm{Y}_{2} \mathrm{O}_{3}\right)_{0.04}\left(\mathrm{Sc}_{2} \mathrm{O}_{3}\right)_{0.06} \\
-\left(\mathrm{ZrO}_{2}\right)_{0.9}\end{array}$ & 0.7 & $\begin{array}{c}\mathrm{Ni}-\mathrm{YSZ}- \\
\mathrm{CeO}_{2}\end{array}$ & LSM & $\begin{array}{c}\mathrm{CH}_{4} \text {-air } \\
R_{\text {mix }}=1.9\end{array}$ & 600 & 0.8 & 8.5 \\
\hline \multirow{2}{*}[137]{} & \multirow{2}{*}{2001} & YSZ & 0.5 & \multirow{2}{*}{ Ni-SDC } & \multirow{2}{*}{$\mathrm{SSC}$} & \multirow{2}{*}{$\begin{array}{l}\mathrm{C}_{2} \mathrm{H}_{6} \text {-air } \\
R_{\text {mix }}=1\end{array}$} & 500 & \multirow{2}{*}{0.9} & \\
\hline & & SDC & 0.15 & & & & 450 & & 280 \\
\hline [93] & 2001 & SDC & 0.15 & Ni-SDC & $\mathrm{SSC}$ & $\mathrm{C}_{4} \mathrm{H}_{10}$-air & 450 & 0.9 & 245 \\
\hline [123] & 2001 & CZI10 & 1 & Ni-CZI10 & $\mathrm{Pt}$ & $\mathrm{CH}_{4}$-air & 800 & 0.4 & 0.01 \\
\hline$[80]$ & 2002 & SDC & 0.15 & $\mathrm{Ni}-\mathrm{SDC}$ & $\mathrm{SSC}$ & $\begin{array}{l}\mathrm{CH}_{4} \text {-air } \\
R_{\text {mix }}=1\end{array}$ & 550 & 0.82 & 644 \\
\hline \multirow{3}{*}[125]{} & \multirow{3}{*}{2003} & \multirow{3}{*}{ YSZ } & \multirow{3}{*}{0.1} & \multirow{3}{*}{ Ni-YSZ } & LSM & \multirow{3}{*}{$\begin{array}{c}\mathrm{C}_{3} \mathrm{H}_{8} \text {-air } \\
R_{\text {mix }}=1 / 1.8\end{array}$} & \multirow{3}{*}{600} & \multirow{3}{*}{0.9} & 4 \\
\hline & & & & & $\mathrm{SSC}$ & & & & 14 \\
\hline & & & & & LSCF & & & & 16 \\
\hline
\end{tabular}


Table 2. Cont.

\begin{tabular}{|c|c|c|c|c|c|c|c|c|c|}
\hline Reference & Year & Electrolyte & $\begin{array}{c}\text { Electrolyte } \\
\text { thickness }(\mathbf{m m})\end{array}$ & Anode & Cathode & $\begin{array}{c}\text { Gas } \\
\text { mixture }\end{array}$ & $\begin{array}{c}T_{\text {furnace }} \\
\left({ }^{\circ} \mathbf{C}\right)\end{array}$ & $\begin{array}{c}\text { OCV } \\
\text { (V) }\end{array}$ & $\underset{\left(\mathbf{m W} \cdot \mathbf{c m}^{-2}\right)}{\boldsymbol{P}_{\max }}$ \\
\hline$[53]$ & 2003 & YSZ & & Ni-YSZ & LSM & $\begin{array}{c}\mathrm{C}_{3} \mathrm{H}_{8} \text {-air } \\
R_{\text {mix }}=1 / 1.8\end{array}$ & 600 & & 4.25 \\
\hline$[126] /[127]$ & $2003 / 2005$ & SDC & & $\mathrm{Ni}-\mathrm{SDC}$ & LSCF-SDC & $\begin{array}{c}\mathrm{C}_{3} \mathrm{H}_{8} \text {-air } \\
R_{\text {mix }}=1 / 1.8\end{array}$ & 600 & 0.8 & 140 \\
\hline$[128]$ & 2004 & SDC & 0.5 & Ni-SDC & LSCF-SDC & $\begin{array}{c}\mathrm{C}_{3} \mathrm{H}_{8} \text {-air } \\
R_{\text {mix }}=1 / 1.8\end{array}$ & 650 & 0.8 & 210 \\
\hline$[26,27]$ & 2004 & YSZ & 0.2 & Ni-YSZ & LSM & $\begin{array}{l}\mathrm{CH}_{4} \text {-air } \\
R_{\text {mix }}=2\end{array}$ & 800 & 1.02 & 85 \\
\hline$[97]$ & 2004 & SDC & 0.8 & Ni-SDC & $\mathrm{SSC}$ & $\begin{array}{c}\mathrm{C}_{3} \mathrm{H}_{8} \text {-air } \\
R_{\text {mix }}=1 / 1.9\end{array}$ & 600 & 0.7 & 18 \\
\hline$[141] /[127]$ & $2004 / 2005$ & SDC & 0.5 & Ni-SDC & SDC-LSCF & $\begin{array}{c}\mathrm{C}_{3} \mathrm{H}_{8} \text {-air } \\
R_{\text {mix }}=1 / 1.8\end{array}$ & 575 & 0.8 & 110 \\
\hline \multirow{3}{*}{ [118] } & \multirow{3}{*}{2004} & \multirow{3}{*}{ YSZ } & \multirow{3}{*}{0.1} & Ni-YSZ & \multirow{3}{*}{ LSCF } & \multirow{3}{*}{$\begin{array}{c}\mathrm{C}_{3} \mathrm{H}_{8} \text {-air } \\
R_{\text {mix }}=1 / 1.8\end{array}$} & 550 & 0.87 & \\
\hline & & & & $\mathrm{Ni}-\mathrm{CGO}$ & & & 600 & 0.86 & \\
\hline & & & & $\mathrm{Ni}-\mathrm{CSO}$ & & & $600-635$ & 0.84 & \\
\hline$[99,100] /[101]$ & $2004 / 2005$ & YSZ & 0.2 & Ni-CGO & $\mathrm{SSC}$ & $\begin{array}{c}\mathrm{CH}_{4} \text {-air } \\
R_{\text {mix }}=1.7\end{array}$ & 600 & 0.68 & 468 \\
\hline \multirow{2}{*}{ [138] } & \multirow{2}{*}{2005} & YSZ & \multirow{2}{*}{0.5} & \multirow{2}{*}{ Ni-LSCM } & \multirow{2}{*}{$\mathrm{SSC}$} & \multirow{2}{*}{$\begin{array}{c}\mathrm{CH}_{4} \text {-air } \\
R_{\text {mix }}=1.25\end{array}$} & \multirow{2}{*}{800} & \multirow{2}{*}{0.6} & 5 \\
\hline & & $\mathrm{BaLaIn}_{2} \mathrm{O}_{5.5}$ & & & & & & & 38 \\
\hline \multirow{2}{*}{ [134] } & \multirow{2}{*}{2005} & \multirow{2}{*}{ YSZ } & \multirow{2}{*}{0.2} & \multirow{2}{*}{ Ni-YSZ } & $\mathrm{Nd}_{1.95} \mathrm{NiO}_{4+\delta}$ & \multirow{2}{*}{$\begin{array}{c}\mathrm{CH}_{4} \text {-air } \\
R_{\mathrm{mix}}=2.6\end{array}$} & \multirow{2}{*}{700} & \multirow{2}{*}{1} & 55 \\
\hline & & & & & LSM & & & & 34 \\
\hline$[135]$ & 2006 & $\mathrm{CGO}$ & 0.5 & Ni-CGO & LSCO-CGO & $\begin{array}{c}\mathrm{C}_{3} \mathrm{H}_{8} \text {-air } \\
R_{\text {mix }}=0.58\end{array}$ & 625 & 0.85 & 65 \\
\hline
\end{tabular}


Table 2. Cont.

\begin{tabular}{|c|c|c|c|c|c|c|c|c|c|}
\hline Reference & Year & Electrolyte & $\begin{array}{c}\text { Electrolyte } \\
\text { thickness (mm) }\end{array}$ & Anode & Cathode & $\begin{array}{c}\text { Gas } \\
\text { mixture }\end{array}$ & $\begin{array}{l}T_{\text {furnace }} \\
\left({ }^{\circ} \mathbf{C}\right)\end{array}$ & $\begin{array}{l}\text { OCV } \\
\text { (V) }\end{array}$ & $\begin{array}{c}\boldsymbol{P}_{\max } \\
\left(\mathbf{m W} \cdot \mathbf{c m}^{-2}\right)\end{array}$ \\
\hline \multirow{2}{*}{ [129] } & \multirow{2}{*}{2006} & \multirow{2}{*}{ SDC } & & \multirow{2}{*}{ Ni-YDC } & LSCF & \multirow{2}{*}{$\begin{array}{l}\mathrm{CH}_{4} \text {-air } \\
R_{\text {mix }}=1\end{array}$} & \multirow{2}{*}{800} & 0.7 & 186 \\
\hline & & & & & LSM & & & 0.46 & 30 \\
\hline [139] & 2006 & $\mathrm{CGO}$ & 1 & $\mathrm{Ni}-\mathrm{CGO}$ & $\mathrm{SSC}$ & $\begin{array}{l}\mathrm{CH}_{4} \text {-air } \\
R_{\text {mix }}=2\end{array}$ & $\begin{array}{c}733 \\
\left(T_{\text {anode }}\right)\end{array}$ & 0.85 & 70 \\
\hline [119] & 2007 & YSZ & 0.5 & $\begin{array}{c}\mathrm{Ni}-\mathrm{ZrO}_{2-} \\
\mathrm{CeO}_{2}\end{array}$ & LSM & $\begin{array}{l}\mathrm{CH}_{4} \text {-air } \\
R_{\text {mix }}=1\end{array}$ & 950 & 1.1 & 53 \\
\hline$[121] /[81]$ & $2007 / 2009$ & SDC & 0.2 & $\begin{array}{l}\text { Ni-Pd- } \\
\text { SDC }\end{array}$ & $\mathrm{SSC}$ & $\begin{array}{l}\mathrm{CH}_{4} \text {-air } \\
R_{\text {mix }}=2\end{array}$ & 600 & 0.8 & 97 \\
\hline$[92] /[94]$ & $2007 / 2009$ & YSZ & 0.5 & Ni-YSZ & LSM-YSZ & $\begin{array}{l}\mathrm{CH}_{4} \text {-air } \\
R_{\text {mix }}=1\end{array}$ & 700 & 0.92 & 114 \\
\hline [124] & 2008 & YSZ & 0.4 & Ni-YSZ & LSM & $\begin{array}{l}\mathrm{CH}_{4} \text {-air } \\
R_{\text {mix }}=2\end{array}$ & 690 & & 1.14 \\
\hline$[142,143]$ & 2008 & YSZ & 0.4 & $\mathrm{Ni}-\mathrm{CSO}$ & LSM & $\begin{array}{l}\text { Hydrocarbon- } \\
\text { air }\end{array}$ & 800 & 1.1 & 19 \\
\hline [136] & 2009 & $\mathrm{CGO}$ & 0.2 & Ni-CGO & LSCO-CGO & $\begin{array}{c}\mathrm{CH}_{4} \text {-air } \\
R_{\text {mix }}=0.9\end{array}$ & 740 & 0.7 & 280 \\
\hline [133] & 2009 & SDC & 0.3 & Ni-SDC & $\mathrm{Pr}_{0.7} \mathrm{Sr}_{0.3} \mathrm{Fe}_{0.8} \mathrm{Co}_{0.2} \mathrm{O}_{3-\delta}$ & $\begin{array}{l}\mathrm{CH}_{4} \text {-air } \\
R_{\text {mix }}=2\end{array}$ & 600 & 0.73 & 65 \\
\hline
\end{tabular}




\subsection{Planar anode-supported SC-SOFCs}

Voltage losses from ohmic resistance to the ionic conduction are one of the major sources of polarization losses in SOFCs [49]. Reducing the electrolyte thickness permits reducing the ionic conduction path and reducing the ohmic losses. Additionally, the use of thin electrolytes enables lower operating temperatures. However, with the electrolyte being the supporting part of the cell, the mechanical stability is significantly reduced when thin electrolyte substrates are employed. Anode-supported SOFCs offer the advantage of using a thin electrolyte for reduced ohmic resistance on a thick, mechanically supporting anode substrate. Jasinski et al. [53] were the first group of investigating anode-supported SOFCs operated in single-chamber conditions. While Hibino et al. [93] had observed an increase in cell performance when decreasing the electrolyte thickness down to $0.15 \mathrm{~mm}$ in planar electrolyte-supported SC-SOFCs, the anode-supported cell configuration enabled further reduction of the electrolyte thickness down to a few tens of micrometers [28,96,144]. Anode-supported SC-SOFCs exhibited the highest power output measured so far in SC-SOFC technology [145] and were operated at temperatures down to $200{ }^{\circ} \mathrm{C}$ [146]. A detailed summary of the development of planar anode-supported SC-SOFCs is presented in the following sections.

\subsubsection{Materials}

\section{Anode materials}

Similar to electrolyte-supported SC-SOFCs, Ni-based materials are the common anode materials used in the anode-supported cell configuration, and improving their stability and catalytic activity constitutes one of the major research efforts.

The benefits of adding SDC to the Ni-based anode via a sol-gel coating technique were studied [9,12]. Vo et al. [9] used sol-gel coating of Ni-Al anode and LSM cathode with porous SDC to decrease electrode resistance and increase the TPB area of anode-supported cells. Additionally, cracks and pinholes in the SDC electrolyte were covered by this coating process. In a methane-air mixture at $700{ }^{\circ} \mathrm{C}, 305 \mathrm{~mW} \cdot \mathrm{cm}^{-2}$ were obtained. Sol-gel coating with SDC was also used to reduce carbon deposition on the anode of anode-supported Ni-YSZ | YSZ | LSM cells [12]. Due to its oxygen storage capacity and resulting high catalytic activity towards hydrocarbon oxidation, SDC was found to significantly reduce carbon formation in a methane-rich atmosphere and stabilize cell performance during long-term operation.

The addition of a $\mathrm{Ru}$ metal catalyst to a Ni-SDC anode led to an increase in OCV and peak power density due to enhanced $\mathrm{H}_{2}$ formation via butane partial oxidation [146]. Addition of $\mathrm{Pd}$, however, favored the complete oxidation of butane and a performance decrease was observed, in contrast to [147] where the addition of Pd was beneficial to the performance of a SC-SOFC with coplanar electrodes.

Aging experiments at different gas mixing ratios highlighted instability issues of Ni-cermet anodes [96]. In oxygen-rich gas mixtures $\left(R_{\operatorname{mix}}<2\right)$, performance degradation accompanied by oscillations of the OCV occurred due to reduction-oxidation cycles of the nickel cermet. In addition, peak power and current density significantly decreased after aging. The anode near the gas inlet exhibited a white color and increased porosity due to the loss of nickel through formation of volatile 
nickel hydroxide. The formation of $\mathrm{Ni}(\mathrm{OH})_{2}$ was favored in oxygen-rich mixtures where a higher quantity of water vapor was generated [148]. The increased porosity reduced the active electrode surface area and the electrode conductivity. Additionally, the reduction-oxidation of the Ni-cermet enhanced the degradation of the anode by the accompanying volume changes between $\mathrm{Ni}$ and $\mathrm{NiO}$. According to Zhang et al. [64], the reduction-oxidation cycles are accompanied by oscillations in reactant and product concentrations as well as temperature fluctuations over the catalyst. Oxygen reacts with $\mathrm{Ni}$ on the catalyst surface and forms $\mathrm{NiO}$, thereby decreasing the partial oxidation reactions of methane. Methane can then react with $\mathrm{NiO}$ in an endothermic reduction reaction causing a decrease in temperature. Reoxidation of the newly formed Ni follows and the whole cycle starts all over again. Ni-based anodes were also found to be sensitive to carbon deposition which additionally led to a performance drop during aging under current loads near the maximum power density [96]. However, carbon deposition could be excluded to be responsible for voltage fluctuations during cell operation as Kellogg et al. [72,75] confirmed reduction-oxidation cycles of the Ni-anode to cause voltage oscillations in hydrogen-air mixtures.

Similar oscillations of the OCV during aging tests also occurred in the case of SC-SOFCs in the single-face configuration with Ni-YSZ anodes [149] and microstructural changes of the anode part closest to the adjacent cathode were observed [103,150,151]. Additionally, the comparison between nickel-rich (80 wt $\% \mathrm{NiO}$ ) anodes and anodes containing only $55 \mathrm{wt} \%$ of $\mathrm{NiO}$ showed that the long-term stability of nickel-rich anodes was more affected by oxidation-reduction cycles and $\mathrm{Ni}$ loss [104]. The reoxidation of $\mathrm{Ni}$ to $\mathrm{NiO}$ was found to cause a decrease in conductivity and catalytic activity leading to reduced power output [74]. Those results suggest that Ni-based anodes might not be the appropriate anode material for operation in fuel-air mixtures.

\section{Cathode materials}

Research on cathode materials for anode-supported SC-SOFCs can be divided into improving conventional LSM-based cathodes and investigating new materials such as LSCF [28], LSCO [152,153], BSCF [154] or $\mathrm{La}_{0.8} \mathrm{Sr}_{0.2} \mathrm{Sc}_{0.1} \mathrm{Mn}_{0.9} \mathrm{O}_{3}$ (LSSM) [155].

Impregnation of porous LSM cathodes with SDC was shown to enhance the catalytic activity of LSM-based cathodes while reducing their polarization resistance $[9,156]$. The uniformly distributed SDC nanoparticles on LSM improved the activity of the cathode for the oxygen reduction reaction by extending the electrochemical reaction zone from the electrode-electrolyte interface into the electrode [156]. The addition of the ionic conductive SDC phase also enhanced the conduction of oxygen ions to the reaction sites. The electrode polarization resistance decreased by $38 \%$ compared to a pure LSM cathode. Improved electrochemical activity of the composite cathode increased the maximum power output from 125 to $416 \mathrm{~mW} \cdot \mathrm{cm}^{-2}$ at $750{ }^{\circ} \mathrm{C}$ in a methane-air mixture. Comparison of the impedance spectra of pure LSM and SDC impregnated LSM cathodes confirmed a lower polarization resistance for the composite cathode while temperature measurements revealed an increase in activity for methane oxidation when SDC was added to the LSM cathode [157].

By replacing a LSM [53] cathode by LSCF [28], based on previous work on electrolyte-supported cells [128], a performance increase could be obtained. The anode-supported SC-SOFC with a $2 \mu \mathrm{m}$ thick YSZ electrolyte on a Ni-YSZ anode substrate was operated in a methane-air mixture at $R_{\text {mix }}=2$ [28]. For operating temperatures in the range of 625 to $750{ }^{\circ} \mathrm{C}$, OCVs of about $0.8 \mathrm{~V}$ 
were measured which remained stable during $70 \mathrm{~h}$ of aging. The highest peak power density of $120 \mathrm{~mW} \cdot \mathrm{cm}^{-2}$ was obtained at $750{ }^{\circ} \mathrm{C}$ whereas a power output of less than $10 \mathrm{~mW} \cdot \mathrm{cm}^{-2}$ was obtained for cells with LSM [53].

For operation in propane-air gas mixtures, LSCO was shown to be a suitable cathode material which was stable at furnace temperatures of up to $550{ }^{\circ} \mathrm{C}[152,153]$. However, lower performance was obtained as compared to electrolyte-supported cells constructed with the same materials [135]. The very low $R_{\text {mix }}$ of only 0.11 seems questionable [153].

A BSCF perovskite cathode with elevated catalytic activity towards the oxygen reduction reaction was proposed by Shao et al. [154,158] for operation under dual- and single-chamber conditions at intermediate temperatures. BSCF could be used in propane-oxygen mixtures at temperatures of 400 to $575{ }^{\circ} \mathrm{C}$, and, with addition of SDC to BSCF, a peak power density of $440 \mathrm{~mW} \cdot \mathrm{cm}^{-2}$ was measured at $500{ }^{\circ} \mathrm{C}$. During dual-chamber operation with a simple BSCF cathode, peak power densities of $400 \mathrm{~mW} \cdot \mathrm{cm}^{-2}$ at $500{ }^{\circ} \mathrm{C}$ and $1,000 \mathrm{~mW} \cdot \mathrm{cm}^{-2}$ at $600{ }^{\circ} \mathrm{C}$ were obtained. During singlechamber operation, the heat release from the partial fuel oxidation reactions resulted in 150 to $245{ }^{\circ} \mathrm{C}$ higher cell temperatures and consequently in higher power densities than in the dual-chamber mode at nominally lower furnace temperatures. The high cell performances were attributed to a very low electrode resistance and a high oxygen ion conductivity of the BSCF cathode. Additionally, an elevated rate of oxygen diffusion was measured indicating high reaction rates for the oxygen electro-reduction. Also compared to SSC and LSCF cathode materials, BSCF showed low activity for fuel oxidation reactions [154,158], and higher power outputs were obtained for cells with BSCF cathode $[159,160]$. Preliminary investigations demonstrated long-term stability of the BSCF cathode in both dual- and single-chamber operating conditions with no phase segregation or reduction [154,158].

The activity of BSCF for methane oxidation was studied in [145] and [161]. Over a temperature range of 480 to $800{ }^{\circ} \mathrm{C}$, less than $30 \%$ of methane were consumed by $\mathrm{BSCF}$, indicating low activity for methane conversion. Additionally, higher temperatures (over $600{ }^{\circ} \mathrm{C}$ ) were necessary to activate methane conversion over BSCF as compared to ethane or propane oxidation. The main carbon-containing product of the conversion reactions over $\mathrm{BSCF}$ was $\mathrm{CO}_{2}$ and only negligible concentrations of $\mathrm{CO}$ were detected, emphasizing that $\mathrm{BSCF}$ was inactive for partial hydrocarbon oxidation and only slightly active for complete oxidation. The higher chemical stability of methane enabled the use of higher operating temperatures leading to higher reaction kinetics at the electrodes, and higher power densities could be achieved with methane [145] than with propane [154]. The measured power density of $760 \mathrm{~mW} \cdot \mathrm{cm}^{-2}$ was comparable to the performance of conventional dual-chamber SOFCs and was attributed to the excellent activity of BSCF for oxygen electro-reduction and its low activity for methane oxidation.

However, a drawback of BSCF is its low stability in reducing atmospheres which imposes constraints on cell initialization and fabrication [155,162]. LSSM was therefore investigated as cathode material in anode-supported SC-SOFCs with scandia-stabilized zirconia (ScSZ) electrolyte and $\mathrm{Ni}-\mathrm{ScSZ}$ anode [155]. Although LSSM showed a better electrochemical activity for oxygen reduction as compared to LSM, LSSM exhibited higher activity for methane oxidation leading to slightly lower cell performance. 


\section{Electrolyte materials}

Despite the elevated power output using the BSCF cathode, mixed conductivity of the ceria electrolyte at elevated temperatures only led to low OCVs of around $0.7 \mathrm{~V}$ [145]. Tomita et al. [163] found that the addition of a thin $\mathrm{BaCe}_{0.8} \mathrm{Y}_{0.2} \mathrm{O}_{3-\alpha}(\mathrm{BCY})$ layer between two layers of GDC increased the stability of ceria-based electrolytes in reducing atmospheres. The laminated three-layer electrolyte impeded electronic short circuiting which occurs from electronic conductivity due to reduction of GDC at low oxygen partial pressure. In dual-chamber operation, an increase in OCV and power output were obtained by the addition of the BCY layer. The Ni-GDC/GDC-BCY|SSC cells were also successfully operated between 400 and $500{ }^{\circ} \mathrm{C}$ in a methane-air mixture and the multilayer electrolyte showed high chemical stability against fuel-air mixtures and the reaction products. OCVs over $0.9 \mathrm{~V}$ were measured below $550{ }^{\circ} \mathrm{C}$ with a maximum power output of $302 \mathrm{~mW} \cdot \mathrm{cm}^{-2}$ at $500{ }^{\circ} \mathrm{C}$. Operation at higher temperatures was impeded because of the catalytic activity of the SSC cathode towards fuel.

\subsubsection{Effect of operating conditions}

Similar to electrolyte-supported SC-SOFCs, optimal operating parameters depend on cell component materials, cell size, testing setup, the nature of the fuel used, etc. It is therefore difficult to compare results from one study reported in the literature to another. Instead of the exact impact of a parameter on cell functioning, a general behavior should be concluded from the different studies. Higher gas flow rates seem for instance to improve cell performance. Additionally, intermediate temperatures are more beneficial as they correspond to a temperature range of acceptable catalytic activity of the electrode materials. Some examples of the effects of operating parameters on the performance of anode-supported SC-SOFCs are presented to illustrate the development of these cells.

The optimal operating temperature range of anode-supported Ni-SDC | SDC | SDC-SSC cells was investigated for operation in propane-air mixtures [54]. The catalytic activity of Ni-SDC for propane partial oxidation was highest at $400{ }^{\circ} \mathrm{C}$ whereas the SSC cathode was active for the fuel reaction at temperatures over $650^{\circ} \mathrm{C}$. Therefore, the electrode materials restricted the operating temperature of the cell to a range between 400 and $650{ }^{\circ} \mathrm{C}$, and during cell operation, a furnace temperature of $525{ }^{\circ} \mathrm{C}$ enabled the highest power output. At temperatures below $500{ }^{\circ} \mathrm{C}$, poor anode catalytic activity yielded low or near-zero OCV, and at temperatures over $625^{\circ} \mathrm{C}$ the activated cathode caused the OCV to drop. Thermodynamic based considerations where the gases near the anode were assumed to be in thermodynamic equilibrium and where the oxygen partial pressure at the cathode was assumed to equal the one of the incoming gas mixture, identified a propane-to-oxygen ratio of $0.33-0.4$ to yield the highest syngas concentrations within this temperature range. Experimental evaluation of the cell performance confirmed this gas mixing ratio. The effect of propane flow rate on the cell performance also depended on $R_{\text {mix }}$.

Napporn et al. [27,96] investigated the effect of gas mixing ratio, gas flow rate and operating temperature on the cell performance of anode-supported Ni-YSZ|YSZ|LSM SC-SOFCs in methane-air mixtures. The OCV was monitored as a function of $R_{\text {mix }}$ and operating temperature, and the highest $\mathrm{OCV}$ was obtained for $R_{\mathrm{mix}}$ in the vicinity of 2 and a furnace temperature of $800^{\circ} \mathrm{C}$. At very low $R_{\text {mix }}\left(R_{\text {mix }}=0.5\right)$, cermet reoxidation in the oxygen-rich atmosphere significantly affected the 
stability of the OCV independently from the operating temperature. The limiting current density was found to increase with increasing gas flow rate [27] and gas mixing ratio [96]. Similarly, the peak power density depended on the mixing ratio and operating temperature, and the highest power output of $260 \mathrm{~mW} \cdot \mathrm{cm}^{-2}$ was obtained for $R_{\text {mix }}=2$ and at $800{ }^{\circ} \mathrm{C}$ [96]. Decreasing the flow rate shifted the maximum power to oxygen-rich gas mixtures [148]. However, $R_{\operatorname{mix}}=2$ led to better cell stability during aging whereas oxygen-richer gas mixtures caused a significant performance degradation due to nickel volatilization and reduction-reoxidation cycles [96].

For anode-supported Ni-YSZ|YSZ|LSCF cells, the gas flow rate significantly affected the maximum current density while the OCV varied little with the gas flow rate [28]. An increase in gas flow velocity from 200 to $900 \mathrm{~mL} \cdot \mathrm{min}^{-1}$ decreased the resistance to gas diffusion at the electrodes and caused an increase in current density from 300 to $600 \mathrm{~mA} \cdot \mathrm{cm}^{-2}$.

\subsubsection{Low temperature operation}

In an effort to improve the cell performance, Hibino et al. [93] had reduced the thickness of the electrolyte down to $150 \mu \mathrm{m}$ in electrolyte-supported cells. However, at low operating temperatures of $300{ }^{\circ} \mathrm{C}$ in a butane-air mixture, the maximum power output was only $38 \mathrm{~mW} \cdot \mathrm{cm}^{-2}$. In order to improve the cell performance at such low operating temperatures and also enable cell operation at even lower temperatures, the further reduction of the electrolyte thickness became necessary, leading to the use of anode-supported SC-SOFCs [146]. With a $15 \mu \mathrm{m}$ thick GDC electrolyte, a peak power density of $133 \mathrm{~mW} \cdot \mathrm{cm}^{-2}$ was measured at $300{ }^{\circ} \mathrm{C}$ in a butane-air mixture. Operation on methane led to near-zero OCVs at $200-300{ }^{\circ} \mathrm{C}$ whereas with propane and ethane an OCV exceeding $0.8 \mathrm{~V}$ was only obtained at temperatures over $250^{\circ} \mathrm{C}$. With butane as fuel, current could be drawn from the cells even at $200{ }^{\circ} \mathrm{C}$. The low temperature operation was possible because of the heat release during fuel oxidation which increased the real cell temperatures by up to $150^{\circ} \mathrm{C}$.

\subsubsection{Liquid fuels}

Exploiting the heating effect generated by the fuel oxidation reactions, SC-SOFCs were shown to operate on liquid fuels such as dimethyl ether and ethanol at low temperatures of $300{ }^{\circ} \mathrm{C}$ [56]. Based on OCV measurements, optimal flow rate and $R_{\text {mix }}$ could be determined for each fuel. Compared with butane, the catalytic activity of the Ni-SDC anode was relatively low for the partial oxidation of dimethyl ether and ethanol. Additionally, the SSC cathode only became active for fuel oxidation at $400{ }^{\circ} \mathrm{C}$ which corresponded to the actual cell temperature. The addition of catalyst layers $(\mathrm{Ru} / \mathrm{SDC} / \mathrm{Ni}$ in the case of dimethyl ether and $\mathrm{Cu} / \mathrm{Zn} / \mathrm{Al}$ for ethanol) at the anode side caused an increase in $\mathrm{H}_{2}$ and $\mathrm{CO}$ production for both fuels, and an increase in OCV and peak power densities was observed. Specifically, a peak power density of 64 and $117 \mathrm{~mW} \cdot \mathrm{cm}^{-2}$ was reported at $300{ }^{\circ} \mathrm{C}$ for dimethyl ether and ethanol, respectively.

\subsubsection{Thermally self-sustaining SC-SOFCs}

Using the heat evolving from the partial oxidation of the fuel, the cell temperature of SC-SOFCs can be maintained at a sufficiently high level to allow power generation without an external heating 
source [25]. Such thermally self-sustaining SC-SOFCs were operated by Shao et al. with propane as fuel and exhibited peak power densities of $247 \mathrm{~mW} \cdot \mathrm{cm}^{-2}$ and rapid start-ups in less than $1 \mathrm{~min}$. The use of a highly catalytic active layer of $\mathrm{Ru}-\mathrm{CeO}_{2}$ on the Ni-SDC anode enabled ignition of the partial oxidation of propane at reduced temperatures and contributed to an overall higher conversion efficiency and heat generation. Cell start-up was initiated in a preheated furnace at $500{ }^{\circ} \mathrm{C}$. After removal of the cell and adequate thermal insulation, a cell temperature around $580{ }^{\circ} \mathrm{C}$ could be maintained without an external heating system.

A controlled thermal environment for a thermally self-sustaining SC-SOFC could also be provided by the use of a spiral Swiss roll heat exchanger and combustor [159,160,164]. The Pt catalyst of the Swiss roll reactor enabled combustion of the cell exhaust gases so that appropriate operating temperatures for the SC-SOFC could be maintained without external heat inputs. Cell operation using propane and butane as fuel gas was possible with power outputs of the same order of magnitude as compared to operation in an electrically heated furnace.

\subsubsection{Cell initialization}

The reduction process of NiO-YSZ cermet anodes in pure methane was studied by Napporn et al. [140] for anode-supported SC-SOFCs. The main products observed in the outlet gas stream during reduction were $\mathrm{CO}$ and $\mathrm{H}_{2}$ with a little amount of $\mathrm{CO}_{2}$. Temperature measurements showed that the endothermic partial oxidation of $\mathrm{CH}_{4}$ was responsible for the formation of $\mathrm{H}_{2}$ and $\mathrm{CO}$. Additionally, a negative cell potential was recorded due to an elevated oxygen partial pressure at the anode resulting from oxidation reactions of $\mathrm{CO}$ and deposited carbon. The progress of the reduction was indicated by the vanishing of $\mathrm{CO}$ and $\mathrm{CO}_{2}$ in the exhaust gas and was completed after 45 min when a positive cell potential was established. Carbon formation from methane cracking was found to proceed fast with $1 \mathrm{mg}$ being deposited already after $5 \mathrm{~min}$ and more than $20 \mathrm{mg}$ after $40 \mathrm{~min}$. In order to avoid excessive carbon formation and performance decrease (15\% lower power output when exposing the cell to $\mathrm{CH}_{4}$ during $45 \mathrm{~min}$ ), the $\mathrm{NiO}$ anode should be reduced by exposing the cell only for a short time to pure $\mathrm{CH}_{4}$ and then to a methane-air mixture. The time of exposure depends on the amount of $\mathrm{NiO}$ and the anode thickness.

Zhang et al. [162] studied different initialization approaches for a Ni-SDC | SDC | BSCF-SDC cell. Direct initialization in a methane-air mixture did not enable the reduction of the Ni catalyst and no sufficiently high OCV could be measured. Due to poor catalytic activity of the anode for oxygen conversion, the oxygen partial pressure was too high to thermodynamically favor the reduction reaction. In-situ reduction in a methane-air mixture only became possible when a $\mathrm{Ru}-\mathrm{CeO}_{2}$ catalyst was added to the anode [83]. NiO could also be completely reduced through initialization in pure methane [162]. However, carbon deposition in the form of carbon fibers was observed and was identified to originate from methane cracking. Increased porosity in both anode and cathode additionally caused cell distortion and electrode detachment, and no OCV was obtained. In-situ reduction with hydrogen prevented carbon coking and an OCV was instantaneously established within a methane-air mixture. The increase in voltage proceeded very slowly so that a stable OCV of $0.7 \mathrm{~V}$ was only reached after $65 \mathrm{~min}$. Additionally, the BSCF-SDC cathode was unstable in hydrogen leading to the reduction and decomposition of the perovskite phase which could however be restored in a 
methane-air mixture. $350 \mathrm{~mW} \cdot \mathrm{cm}^{-2}$ were drawn from the cell at $600{ }^{\circ} \mathrm{C}$. Ex-situ reduction during the fabrication process less affected the BSCF cathode and a maximum power density of $570 \mathrm{~mW} \cdot \mathrm{cm}^{-2}$ was obtained. $\mathrm{NiO}$ reduction prior to cathode deposition was also employed in [54] to avoid reduction of the SDC-SSC cathode. In hydrogen reducing atmospheres, SSC was completely decomposed and lost its electrical conductivity [165].

$E x$-situ reduction, however, requires enhanced control of the sintering atmospheres during cell fabrication which becomes time consuming and more expensive. Therefore, Zhang et al. [155] investigated LSSM and LSM cathodes for their compatibility with in-situ reduction. Similar to BSCF, the perovskite phase of LSM was destroyed during in-situ reduction of the NiO-ScSZ anode in hydrogen and restored during cell operation in a methane-air mixture. Cells with LSSM cathode could be initialized both by $e x$ - and in-situ reduction without any detrimental effects on cell performance or phase stability of the cathode material.

\subsubsection{Cell stacks}

Series connection of two anode-supported Ni-YSZ |YSZ | LSM-SDC cells enabled the generation of an OCV of over $2 \mathrm{~V}$ and a maximum power output of $371 \mathrm{~mW}$ at $700{ }^{\circ} \mathrm{C}$ in a methane-air mixture with $R_{\text {mix }}=1$ [88]. The two cells were arranged in an anode-facing-cathode configuration separated by a small gap of $0.3 \mathrm{~cm}$ and an $\mathrm{Ag}$ interconnect. Furnace temperature, $R_{\mathrm{mix}}$ and gas flow rate affected the performance output of the single cells and the cell stack. Although the OCV was lowest for $R_{\text {mix }}=1$ and temperatures above $650{ }^{\circ} \mathrm{C}$, fuel-richer gas mixtures and lower temperatures led to higher stack resistance and lower power output. High flow rates were found to reduce the cell resistance and increase the maximum power. Electrode resistance and cell performance were also influenced by the distance separating the anode of one cell from the cathode of the second cell [166]. The cathode of the cell facing the gap could not function well when the distance between the two cells was smaller than $4 \mathrm{~mm}$ as the oxygen partial pressure was disturbed by the reactions occurring at the anode of the other cell.

Due to gas intermixing between anode and cathode of adjacent cells, an anode-facing-cathode configuration of a Ni-SDC $\mid$ SDC | BSCF-SDC two-cell stack yielded a near-zero OCV [25]. A power output of $275 \mathrm{~mW} \cdot \mathrm{cm}^{-2}$ could however be obtained in a thermally self-sustaining operating mode when an anode-facing-anode stack configuration was employed. Compared to a single cell, the OCV was doubled for the two-cell stack.

A novel stack design was proposed by Wei at al. [167] who assembled four single cells in a star-shaped, anode-facing-cathode stack configuration. In a methane-air mixture with $R_{\operatorname{mix}}=1.5$ at $750{ }^{\circ} \mathrm{C}$, the stack delivered an OCV of $3.54 \mathrm{~V}$ and a maximum power output of $421 \mathrm{~mW}$ while the single cells provided $420 \mathrm{~mW} \cdot \mathrm{cm}^{-2}$ each. The advantage of this symmetric stack design consists of uniform gas distribution over the single cells and possible scale-up.

\subsubsection{Comparison of electrolyte- and anode supported SC-SOFCs}

Suzuki et al. compared the performance of electrolyte- and anode-supported Ni-YSZ |YSZ |LSM cells [53]. The anode-supported cells showed an increased sensitivity of the OCV with respect to the operating temperature, leading to significant voltage drops above $500{ }^{\circ} \mathrm{C}$. The electrolyte-supported 
configuration exhibited a constant $\mathrm{OCV}$ of around $0.85 \mathrm{~V}$. However, the anode-supported cells delivered twice as much power below $500{ }^{\circ} \mathrm{C}$ due to lower electrode overpotentials and electrolyte resistance. Comparable performance was obtained from anode-supported cells operated in dual- and single-chamber conditions.

Napporn et al. [27] found that the use of thicker Ni-YSZ anodes in the anode-supported design enhanced the cell stability as compared to thinner anodes in electrolyte-supported cells. The latter were more rapidly affected by aging processes. On the other hand, the thinner NiO-based anodes in electrolyte-supported SC-SOFCs can be reduced faster than the ones in anode-supported cells during cell initialization, and therefore lower amounts of deposited carbon can be expected [140].

\subsubsection{Summary of planar anode supported SC-SOFCs}

A chronological summary of materials, testing parameters and cell performance is given in Table 3 . If cell performance was measured under different testing conditions, the highest cell performance and corresponding testing parameters reported in the reference are listed in the following table. Results for different cell component materials are also presented.

\subsection{Fully porous SC-SOFCs}

Fuel cells with porous electrolytes were discussed by van Gool [35] within his considerations on surface ionic conduction in fuel cells. However, in conventional dual-chamber SOFCs, the necessity for gas separation and gas tightness impedes the use of porous electrolytes as gas leaks have to be completely avoided so that a difference in oxygen partial pressure between the two electrode compartments and a cell voltage can be established. The working principle of SC-SOFCs operated on fuel-air mixtures is based on the difference in catalytic activity of the electrodes for the fuel reactions, and is therefore not affected by a porous electrolyte [70]. The use of non-gas tight, porous electrolytes enables the cost-reduced, low-temperature fabrication of electrolytes by conventional processing techniques, e.g. screen printing of an electrolyte film on top of the anode substrate, followed by a sintering step at reduced temperatures. Thin-film SC-SOFCs with porous electrolytes can also be fabricated by thin-film deposition techniques [168]. However, a minimum electrolyte thickness of $10 \mu \mathrm{m}$ should be respected to physically separate the electrodes and avoid short circuiting between the electrodes through the electrolyte pores [14]. 
Table 3. Summary of planar anode-supported SC-SOFCs.

\begin{tabular}{|c|c|c|c|c|c|c|c|c|c|}
\hline Reference & Year & Electrolyte & $\begin{array}{c}\text { Electrolyte } \\
\text { thickness }(\mu \mathrm{m})\end{array}$ & Anode & Cathode & Gas mixture & $\begin{array}{c}T_{\text {furnace }} \\
\left({ }^{\circ} \mathrm{C}\right)\end{array}$ & $\begin{array}{c}\text { OCV } \\
(\mathrm{V})\end{array}$ & $\begin{array}{c}\boldsymbol{P}_{\max } \\
\left(\mathbf{m W} \cdot \mathbf{c m}^{-2}\right) \\
\end{array}$ \\
\hline$[53]$ & 2003 & YSZ & 10 & Ni-YSZ & LSM & $\begin{array}{c}\mathrm{C}_{3} \mathrm{H}_{8} \text {-air } \\
R_{\text {mix }}=1 / 1.8\end{array}$ & 475 & 0.88 & 3.4 \\
\hline$[28]$ & 2004 & YSZ & 2 & Ni-YSZ & $\mathrm{LSCF}$ & $\begin{array}{l}\mathrm{CH}_{4} \text {-air } \\
R_{\text {mix }}=1 \\
\end{array}$ & 750 & 0.85 & 120 \\
\hline$[154]$ & 2004 & SDC & 20 & Ni-SDC & BSCF-SDC & $\begin{array}{c}\mathrm{C}_{3} \mathrm{H}_{8} \text {-air } \\
R_{\text {mix }}=0.44\end{array}$ & 500 & 0.68 & 440 \\
\hline$[27]$ & 2004 & YSZ & 10 & Ni-YSZ & LSM & $\begin{array}{c}\mathrm{CH}_{4} \text {-air } \\
R_{\text {mix }}=0.88\end{array}$ & 800 & 0.84 & 360 \\
\hline$[54]$ & 2004 & $\mathrm{SDC}$ & $10-20$ & Ni-SDC & SSC-SDC & $\begin{array}{c}\mathrm{C}_{3} \mathrm{H}_{8} \text {-air } \\
R_{\text {mix }}=0.4 \\
\end{array}$ & 525 & 0.68 & 210 \\
\hline$[79]$ & 2004 & YSZ & & Ni-YSZ & LSCF-GDC & $\begin{array}{c}\mathrm{C}_{3} \mathrm{H}_{8} \text {-air } \\
R_{\text {mix }}=0.6\end{array}$ & 750 & 1 & 700 \\
\hline$[25]$ & 2005 & $\mathrm{SDC}$ & 20 & $\mathrm{Ni}-\mathrm{SDC}-\mathrm{Ru}-\mathrm{CeO}_{2}$ & BSCF-SDC & $\begin{array}{c}\mathrm{C}_{3} \mathrm{H}_{8} \text {-air } \\
R_{\text {mix }}=0.44\end{array}$ & $\begin{array}{c}580 \\
\left(T_{\text {cell }}\right) \\
\end{array}$ & 0.7 & 247 \\
\hline [9] & 2005 & SDC & 20 & $\mathrm{Ni}-\mathrm{Al}-\mathrm{SDC}$ & LSM-SDC & $\begin{array}{c}\mathrm{CH}_{4} \text {-air } \\
R_{\text {mix }}=0.65\end{array}$ & 700 & 0.84 & 305 \\
\hline \multirow{3}{*}[146]{} & \multirow{3}{*}{2005} & \multirow{3}{*}{ GDC } & \multirow{3}{*}{15} & Ni-SDC & \multirow{3}{*}{$\mathrm{SSC}$} & \multirow{3}{*}{$\begin{array}{c}\mathrm{C}_{4} \mathrm{H}_{10} \text {-air } \\
R_{\text {mix }}=2\end{array}$} & \multirow{3}{*}{300} & 0.9 & 133 \\
\hline & & & & Ni-SDC-Ru & & & & 0.92 & 176 \\
\hline & & & & Ni-SDC-Pd & & & & 0.8 & 110 \\
\hline$[76]$ & 2005 & YSZ & 10 & Ni-YSZ & LSM & $\begin{array}{c}\mathrm{CH}_{4} \text {-air- } \mathrm{H}_{2} \mathrm{O} \\
R_{\text {mix }}=1.2 \\
\end{array}$ & 700 & 0.95 & 90 \\
\hline$[12]$ & 2006 & YSZ & 30 & Ni-YSZ-SDC & LSM & $\begin{array}{c}\mathrm{CH}_{4} \text {-air } \\
R_{\text {mix }}=1.67 \\
\end{array}$ & 700 & 1.1 & 280 \\
\hline$[96]$ & 2006 & YSZ & 10 & Ni-YSZ & LSM & $\begin{array}{l}\mathrm{CH}_{4} \text {-air } \\
R_{\text {mix }}=2\end{array}$ & 800 & 1.1 & 260 \\
\hline$[145,161]$ & 2006 & SDC & $15-20$ & $\mathrm{Ni}-\mathrm{SDC}$ & BSCF-SDC & $\begin{array}{c}\mathrm{CH}_{4} \text {-air } \\
R_{\text {mix }}=1.16\end{array}$ & 650 & 0.7 & 760 \\
\hline$[163]$ & 2006 & GDC-BCY & 26 & Ni-SDC & $\mathrm{SSC}$ & $\begin{array}{l}\mathrm{CH}_{4} \text {-air } \\
R_{\text {mix }}=2\end{array}$ & 500 & 0.9 & 302 \\
\hline
\end{tabular}


Table 3. Cont.

\begin{tabular}{|c|c|c|c|c|c|c|c|c|c|}
\hline$\lceil 144\rceil$ & 2006 & YSZ & 8 & Ni-YSZ & LSM & $\mathrm{CH}_{4}$-air & 700 & 1 & 398 \\
\hline [140] & 2006 & YSZ & 10 & Ni-YSZ & LSM & $\begin{array}{l}\mathrm{CH}_{4} \text {-air } \\
R_{\text {mix }}=2\end{array}$ & 700 & 1.03 & 225 \\
\hline$[153]$ & 2007 & CGO & 15 & Ni-CGO & LSCO-CGO & $\begin{array}{c}\mathrm{C}_{3} \mathrm{H}_{8} \text {-air } \\
R_{\text {mix }}=0.11\end{array}$ & 500 & 0.7 & 38 \\
\hline \multirow{3}{*}[56]{} & \multirow{3}{*}{2007} & \multirow{3}{*}{ GDC } & \multirow{3}{*}{15} & $\mathrm{Ni}-\mathrm{SDC}$ & \multirow{3}{*}{$\mathrm{SSC}$} & $\begin{array}{l}\mathrm{C}_{4} \mathrm{H}_{10} \text {-air } \\
R_{\text {mix }}=0.5\end{array}$ & \multirow{3}{*}{300} & 0.9 & 59 \\
\hline & & & & Ni-SDC-Ru & & $\begin{array}{l}\text { Dimethyl } \\
\text { ether-air }\end{array}$ & & 0.75 & 64 \\
\hline & & & & $\mathrm{Ni}-\mathrm{SDC}-\mathrm{Cu} / \mathrm{Zn} / \mathrm{Al}$ & & $\mathrm{C}_{2} \mathrm{H}_{5} \mathrm{OH}$-air & & 0.8 & 117 \\
\hline$[57]$ & 2007 & YSZ & 8 & Ni-YSZ & LSM & $\begin{array}{l}\mathrm{CH}_{4} \text {-air } \\
R_{\text {mix }}=1 \\
\end{array}$ & 600 & 0.94 & 220 \\
\hline$[88]$ & 2007 & YSZ & 15 & Ni-YSZ & LSM-SDC & $\begin{array}{l}\mathrm{CH}_{4} \text {-air } \\
R_{\text {mix }}=1 \\
\end{array}$ & 650 & 0.96 & 300 \\
\hline \multirow{2}{*}[159,160]{} & \multirow{2}{*}{2007} & \multirow{2}{*}{ SDC } & \multirow{2}{*}{20} & \multirow{2}{*}{$\mathrm{Ni}-\mathrm{SDC}$} & SSC-SDC & $\begin{array}{l}\mathrm{C}_{4} \mathrm{H}_{10} \text {-air } \\
R_{\text {mix }}=0.5\end{array}$ & \multirow{2}{*}{550} & 0.6 & 250 \\
\hline & & & & & BSCF-SDC & $\begin{array}{c}\mathrm{C}_{3} \mathrm{H}_{8} \text {-air } \\
R_{\text {mix }}=1 / 1.54\end{array}$ & & 0.68 & 420 \\
\hline \multirow{2}{*}[156]{$/[167]$} & \multirow{2}{*}{$2007 / 2009$} & \multirow{2}{*}{ YSZ } & \multirow{2}{*}{8} & \multirow{2}{*}{ Ni-YSZ } & LSM & \multirow{2}{*}{$\begin{array}{c}\mathrm{CH}_{4} \text {-air } \\
R_{\mathrm{mix}}=1.5 \\
\end{array}$} & \multirow{2}{*}{750} & 0.92 & 125 \\
\hline & & & & & LSM-SDC & & & 0.97 & 416 \\
\hline$[162]$ & 2008 & SDC & $20-30$ & $\mathrm{Ni}-\mathrm{SDC}$ & BSCF-SDC & $\begin{array}{l}\mathrm{CH}_{4} \text {-air } \\
R_{\text {mix }}=1 \\
\end{array}$ & 600 & 0.75 & 570 \\
\hline$[166]$ & 2009 & YSZ & 15 & Ni-YSZ & LSM-SDC & $\begin{array}{l}\mathrm{CH}_{4} \text {-air } \\
R_{\text {mix }}=1 \\
\end{array}$ & 700 & 0.9 & 150 \\
\hline \multirow{2}{*}{ [155] } & \multirow{2}{*}{2009} & \multirow{2}{*}{$\mathrm{ScSZ}$} & \multirow{2}{*}{$20-30$} & \multirow{2}{*}{ Ni-ScSZ } & LSM & \multirow{2}{*}{$\begin{array}{c}\mathrm{CH}_{4} \text {-air } \\
R_{\text {mix }}=1.3\end{array}$} & \multirow{2}{*}{850} & 0.95 & 275 \\
\hline & & & & & LSSM & & & 0.9 & 250 \\
\hline [83] & 2009 & $\mathrm{ScSZ}$ & 30 & $\mathrm{Ni}-\mathrm{ScSZ}-\mathrm{Ru}-\mathrm{CeO}_{2}$ & LSM & $\begin{array}{c}\mathrm{CH}_{4} \text {-air } \\
R_{\text {mix }}=1.3 \\
\end{array}$ & 850 & 0.95 & 327 \\
\hline
\end{tabular}


Two types of SC-SOFCs with porous electrolytes can be distinguished depending on the gas-flow configuration [169]. In the first type, the dense electrolyte of a conventional SOFC is replaced by a porous electrolyte and the fuel cell is located in the gas flow creating a flow-by configuration (Figure 7a), as generally employed in SC-SOFC testing. The porosity of the electrolyte enables surface ionic conduction [35] and an increased conductivity of the electrolyte [87]. In a flow-through configuration (Figure $7 \mathrm{~b}$ ), the reaction gases have to pass through the first electrode and the electrolyte in order to reach the opposite electrode. The flow-through configuration was shown to enhance mass transport to the electrodes and to lead to higher cell performance as compared to flow-by configurations [1]. For both flow regimes, the cell performance is significantly affected by the gas flow rate $[4,87]$.

Figure 7. Schematic representation of fully-porous SC-SOFC in (a) flow-by and (b) flowthrough configuration.

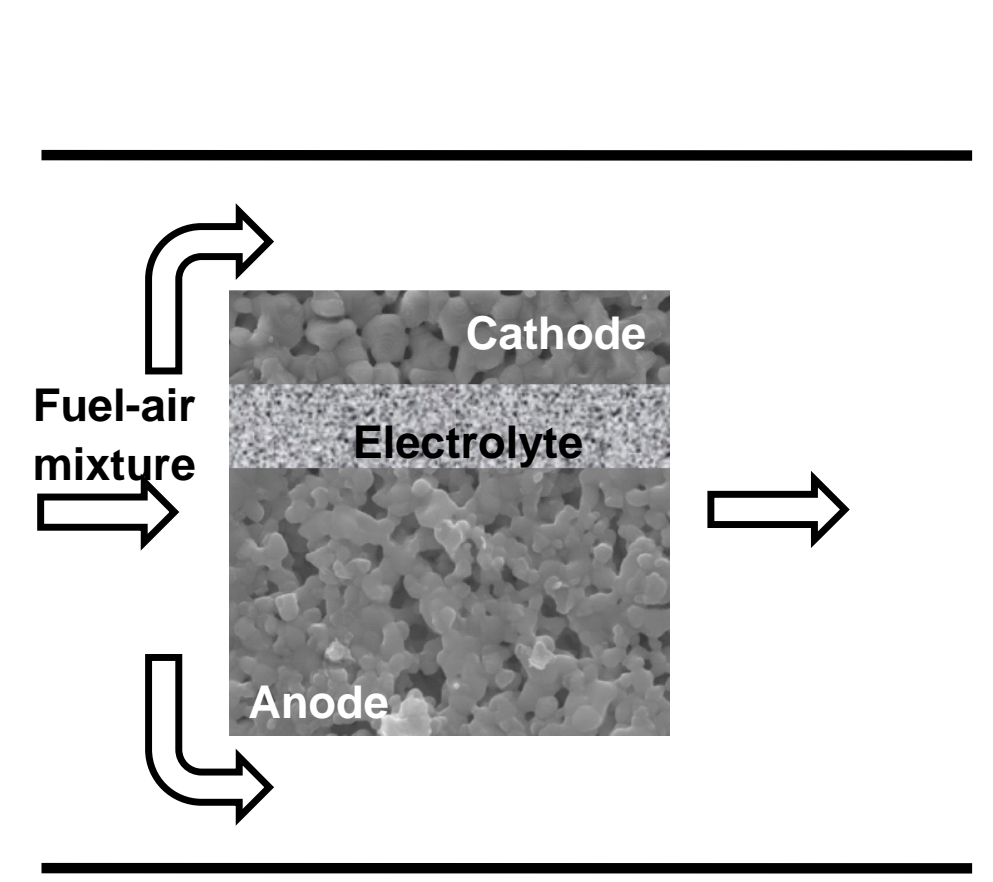

(a)

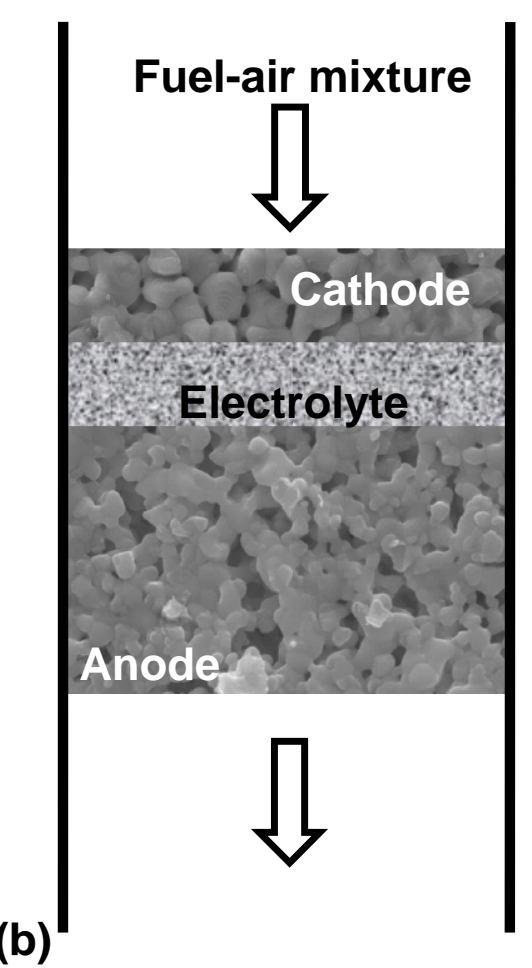

\subsubsection{Flow-by fully-porous SC-SOFCs}

Suzuki et al. $[78,87]$ compared the performance of anode-supported SC-SOFCs (Ni-YSZ | YSZ |LSCF) with dense and porous electrolyte operated in the flow-by regime. The fully-porous cell showed an OCV of 0.68 to $0.78 \mathrm{~V}$ as a function of gas flow rate whereas an OCV above $0.8 \mathrm{~V}$ was measured for the cell with a dense electrolyte. The diffusion of reaction products through the porous electrolyte to the cathode was supposed to induce a lower difference in oxygen partial pressure between the electrodes and decrease the OCV of the fully-porous SC-SOFC. Higher gas flow rates permitted maintaining the oxygen gradient and increasing the OCV while at the same time reducing the cell resistance and improving the cell performance through an increase in cell temperature. A maximum power density of $660 \mathrm{~mW} \cdot \mathrm{cm}^{-2}$ was obtained at $606{ }^{\circ} \mathrm{C}$ and a gas flow rate of $900 \mathrm{~mL} \cdot \mathrm{min}^{-1}$. An 
increased conductivity of the porous electrolyte was found, probably due to the contribution of surface ionic conduction. The current efficiency was about $4-8 \%$. The fully-porous anode-supported SC-SOFC was later patented in [170] where a single-face SC-SOFC with a porous electrolyte was also proposed.

\subsubsection{Flow-through fully-porous SC-SOFCs}

As a variation of Dyer's single-chamber fuel cell [38], Riess et al. [70] suggested a simplified cell structure with a thin, porous electrolyte on a conductive substrate in a flow-through configuration. Such a supported mixed-gas fuel cell (S-MGFC) was experimentally shown to enable the generation of an OCV $[10,11,71]$. The S-MGFC consisted of a dense conductive substrate with a porous electrolyte and an outer, porous electrode on top. The dense substrate served either solely as inner electrode or it was coated with a thin metal layer. Only the outer electrode was directly exposed to the gas mixture which reached the conductive support on the opposite side by diffusing through the pores of the outer electrode and electrolyte. An OCV of up to $0.55 \mathrm{~V}$ could be generated, but depended on electrode composition, electrode selectivity and operating temperature. Cell polarization revealed a high internal cell resistance for the tested S-MGFCs.

Based on a stack design by Priestnall et al. [1], Riess et al. [14] demonstrated the feasibility of fabricating a compact stack of 17 elements of alternating porous layers of anode, electrolyte and cathode. In flow-through operation, the gas mixture would enter the stack at the top end and the exhaust gas would leave the stack at the lower end. For a layer thickness of about $10 \mu \mathrm{m}$ for each component (including the interconnects), a stack with 100 single cells was estimated to provide $5 \mathrm{~kW}$ of power.

The first experimental proof of flow-through operation of a fully-porous SC-SOFC (Figure 7b) was provided by Buergler [4]. The cathode was exposed first to the incoming methane-air gas mixture which then passed through cathode and electrolyte to reach the anode. The cell delivered $10 \mathrm{~mW} \cdot \mathrm{cm}^{-2}$ at an anode temperature of $733{ }^{\circ} \mathrm{C}, R_{\text {mix }}=1$ and a flow rate of $1,000 \mathrm{~mL} \cdot \mathrm{min}^{-1}$. The OCV was found to depend on the flow rate and gas composition as at low flow rates below $250 \mathrm{~mL} \cdot \mathrm{min}^{-1}$, reaction products from the anode could diffuse back to the cathode and led to a drop of the oxygen partial pressure at the cathode side. Additionally, oxygen-rich methane-air mixtures were beneficial to establish a high oxygen partial pressure at the cathode. Reducing the operating temperature also increased the OCV as the catalytic activity of the SSC cathode for fuel reactions was reduced.

\subsection{SC-SOFCs with coplanar electrodes}

In (single-face) SC-SOFCs with coplanar electrodes, both anode and cathode are situated on the same side of the electrolyte. The gap between adjacent electrodes is bridged by the electrolyte, which provides an ion conduction path from one catalyst to another. This type of SC-SOFC is also called a surface-conduction SC-SOFC [171]. The basic design of SC-SOFCs with coplanar electrodes consists of a side-by-side electrode pattern of parallel electrode lines [36] or electrode strips [14]. Anode and cathode strips can also be arranged in an alternating fashion on the same side of the electrolyte to form coplanar electrode arrays [172] or interdigitated, comblike electrode patterns [173,174] to increase the effective electrode area (see Figure 8). Strip or interdigitated electrode configurations are also used in 
sensor technology $[45,175]$ and in addition to SOFCs, the strip cell design was proposed for MR-DMFCs [22]. A new design approach with polygonal or circular shaped electrodes arranged alternately on the electrolyte surface was patented in [176] and arbitrarily shaped electrode structures were reported in [177].

Figure 8. Schematic representation of SC-SOFC with coplanar interdigitated electrodes.

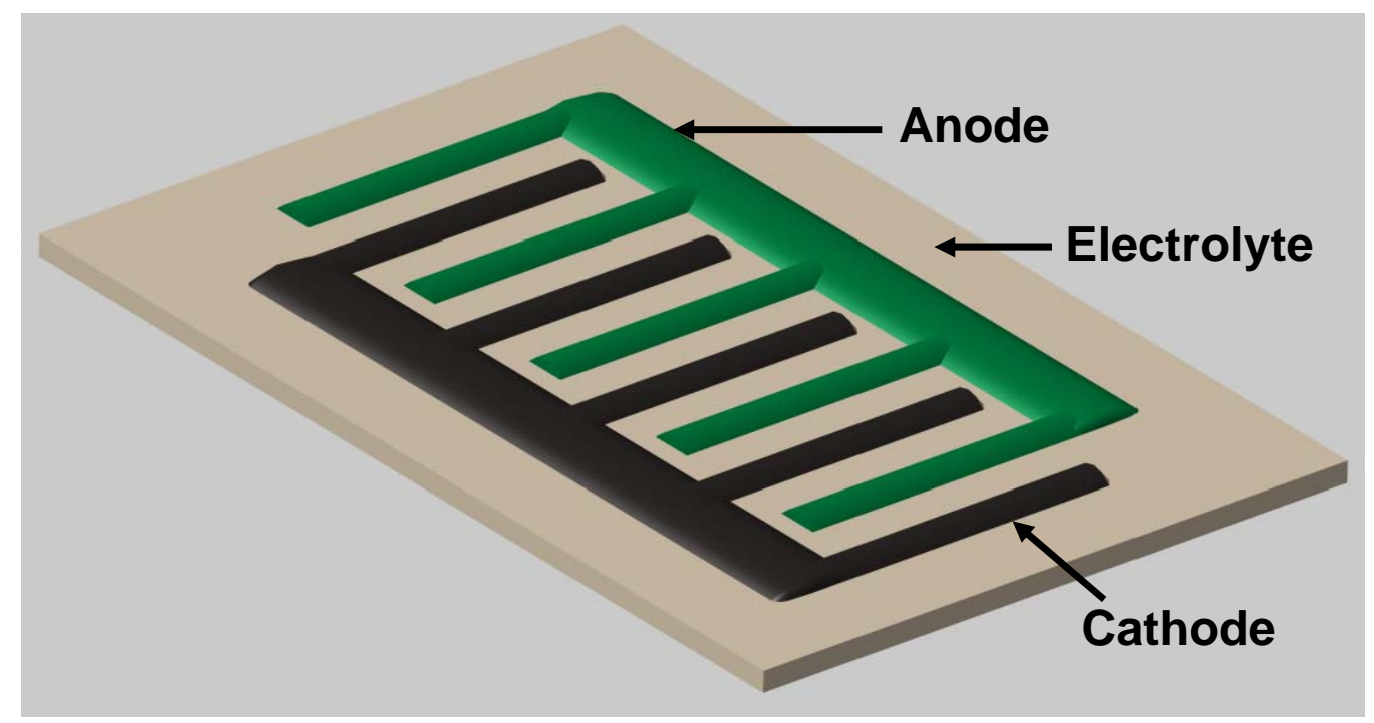

The advantage of the coplanar electrode configuration over the dual-face configuration is the possibility to use a thick, mechanically strong electrolyte substrate. Dual-face designs require very thin electrolytes to reduce ohmic resistance and losses, but those thin films are not only fragile but also involve elevated fabrication costs. In the case of cells with coplanar electrodes, the ohmic resistance is determined by the gap size between adjacent anodes and cathodes and can therefore be decreased by decreasing the inter-electrode distance while maintaining a thick electrolyte substrate. The result is a higher mechanical and thermomechanical stability of the cell and enhanced integration compatibility for packaging and stack assembly. Thick, porous electrolytes can also be used in the single-face configuration [170]. Additionally, the coplanar electrode configuration enables serial and parallel connection of multiple single cells on the electrolyte substrate [174].

\subsubsection{Development of SC-SOFCs with coplanar electrodes}

The concept of fuel cells with coplanar electrodes was introduced in 1965 by van Gool [35] based on the idea of ion transport via surface migration between electrode catalysts on the same side of a solid electrolyte. An interdigitated electrode structure was also proposed. A gap size of $1 \mu \mathrm{m}$ was suggested for the generation of $1 \mathrm{~V}$ in a surface-migration cell, making the use of gas mixtures necessary. Van Gool pointed out that challenges for this type of fuel cell included suitable fabrication techniques, highly selective electrode materials, elevated surface conductivity of the electrolyte and explosion risks of gas mixtures.

Based on the surface-migration principle, Louis et al. [36] patented solid electrolyte fuel cells with closely-spaced, rectangular electrodes on the same side of the electrolyte for room temperature operation in separated fuel-air gas streams or gas mixtures. Single cells consisted of one Pt anode and 
one $\mathrm{SrRuO}_{3}$ cathode arranged side-by-side on an alumina electrolyte. Although photolithography was suggested as suitable fabrication technique to fabricate cells with small inter-electrode gaps for improved cell performance, the cell components were fabricated by painting the electrolyte slurry on top of a substrate and painting electrode slurries with inter-electrode gaps of 0.3 to $0.4 \mathrm{~mm}$ onto the electrolyte. Operation of a single cell at room temperature in a hydrogen-air mixture gave an OCV of $0.67 \mathrm{~V}$ and a maximum power of $0.32 \mu \mathrm{W} \cdot \mathrm{cm}^{-2}$. A similar device with reduced gas channel dimensions was later patented in 2005 [178,179].

The feasibility of SC-SOFCs with coplanar electrodes was experimentally proven by Hibino et al. in 1995 [107]. Later patented [15], the side-by-side design was proposed for the simplification of SOFC systems. The first SC-SOFC with coplanar electrodes consisted of one Pd and one Au electrode line arranged parallel on a $\mathrm{BaCe}_{0.8} \mathrm{Gd}_{0.2} \mathrm{O}_{3-\alpha}$ electrolyte. An OCV of $0.7 \mathrm{~V}$ and a maximum current of $24 \mathrm{~mA}$ were generated at $950^{\circ} \mathrm{C}$ in a methane-oxygen mixture $\left(R_{\operatorname{mix}}=2\right)$ [107].

\subsubsection{Performance considerations}

The working principle of SC-SOFCs with coplanar electrodes is schematically shown in Figure 9 and is similar to that of dual-face SC-SOFCs. $\mathrm{H}_{2}$ and $\mathrm{CO}$ are formed at the anode by the partial oxidation of the fuel and are electrochemically reduced at the anode-electrolyte interface by reaction with oxygen ions coming from the cathode.

Figure 9. Schematics of the operating principle of SC-SOFCs with coplanar electrodes; $d$ is the inter-electrode spacing whereas $w$ denotes the electrode width.

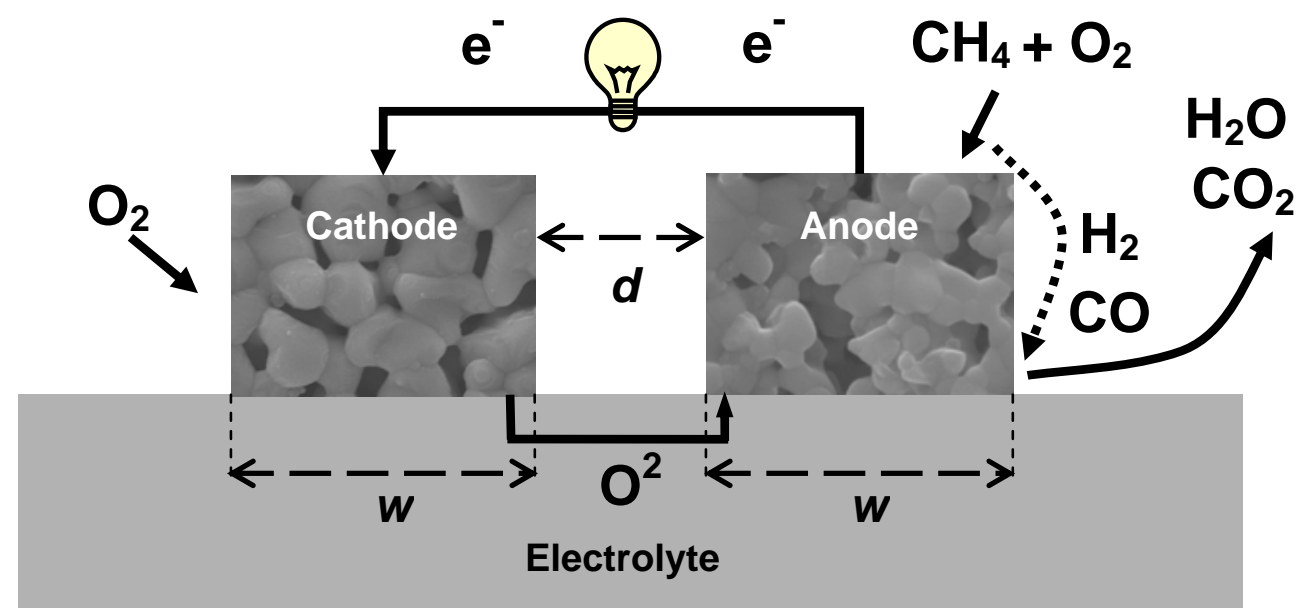

The transport of oxygen ions mainly occurs at the electrolyte surface and strongly depends on the electrolyte surface morphology [174]. In the case of a $\mathrm{BaCe}_{0.8} \mathrm{Gd}_{0.2} \mathrm{O}_{3-\alpha}$ electrolyte, a smoothly polished surface enabled a surface ionic conductivity similar to its bulk conductivity and led to a smaller ohmic resistance and better cell performance, as compared to cells composed of electrolytes with roughened surface [174]. Similarly, reduction of the ohmic cell resistance and increase in peak power density by reducing the electrolyte surface roughness were found for an SDC electrolyte [147]. A decrease in surface roughness from 1.6 to $0.06 \mu \mathrm{m}$ led to an increase in power density from 68 to $90 \mathrm{~mW} \cdot \mathrm{cm}^{-2}$ for a fixed gap size of $1 \mathrm{~mm}$ and operation in ethane-air mixtures at $600{ }^{\circ} \mathrm{C}$. 
In addition to the electrolyte surface morphology, the electrode feature sizes, that is, electrode width $w$ and inter-electrode gap $d$ (see Figure 9), affect the ohmic cell resistance [69,107,117,147,150,180]. In a theoretical study on SC-SOFCs with coplanar electrodes, based on electrode and electrolyte resistance considerations [173], maximum performance was calculated for very small electrode widths and gap sizes on the order of only a few micrometers to minimize the ohmic resistance. Comparison of different inter-electrode distances $(10,20,40$ and $80 \mu \mathrm{m})$ by using the finite element method (FEM) also identified maximum cell performance for the smallest studied gap size [181-183]. The first experimental confirmation of the size effect was provided by Hibino et al. [107] for a cell with parallel $\mathrm{Pd}$ and $\mathrm{Au}$ electrode lines on a $\mathrm{BaCe}_{0.8} \mathrm{Gd}_{0.2} \mathrm{O}_{3-\alpha}$ electrolyte. Reducing the inter-electrode distance from 5 to $0.5 \mathrm{~mm}$ led to an increase in the maximum current from 8 to $24 \mathrm{~mA}$ at $950{ }^{\circ} \mathrm{C}$ in a methane-oxygen mixture $\left(R_{\operatorname{mix}}=2\right)$. The OCV was found to be independent of the variation of the inter-electrode gap [180,184,185], which principally affected the ohmic resistance of the electrolyte [147].

Similarly, for a cell with coplanar electrodes of Ni-SDC and SSC on an SDC electrolyte tested at $600{ }^{\circ} \mathrm{C}$ in a $\mathrm{C}_{2} \mathrm{H}_{6}$-air mixture, a reduction of the gap size from 3 to $0.5 \mathrm{~mm}$ (electrode width fixed at $0.5 \mathrm{~mm}$ ) caused an increase in peak power density from 38 to $193 \mathrm{~mW} \cdot \mathrm{cm}^{-2}$, whereas the power density increased from 90 to $130 \mathrm{~mW} \cdot \mathrm{cm}^{-2}$ when the electrode width was decreased from 1 to $0.5 \mathrm{~mm}$ (gap size fixed at $1 \mathrm{~mm}$ ) [147]. Compared to a dual-face cell with an electrolyte thickness equal to the inter-electrode gap of the single-face SC-SOFC, the latter exhibited a higher ohmic resistance and lower cell performance. This difference was due to a longer ion conduction path (which corresponds to $2 w+d$, with $w$ the electrode width and $d$ the inter-electrode distance, see Figure 9) in the single-face cell, where the electrode widths have to be taken into account in addition to the electrode distance $[117,137,147]$. By decreasing the electrode widths to match the ionic path, similar performance between dual- and single-face SC-SOFCs could be obtained [147].

However, there seem to be certain limits on how far the miniaturization of the electrode feature sizes can actually be useful. Despite an increase in power output by reducing the electrode width, larger electrodes were found to be more stable during aging [150]. Nickel loss and destabilization affected the whole surface of small electrodes, whereas larger electrodes were only partially degraded. Also, for the smallest cell reported so far, with two parallel electrodes spaced only $5 \mu \mathrm{m}$ apart, very poor performance was obtained [186]. The low operating temperature of $400{ }^{\circ} \mathrm{C}$ and the used electrode materials (Pt and $\mathrm{Au}$ ) might also contribute to the low voltage output. A minimum or critical electrode width was identified for SC-SOFCs with one electrode pair, below which the available electrode surface area was too small to enable the generation of an OCV [151]. Cells with electrode widths near the critical size exhibited a non-zero, but highly fluctuating OCV, whereas only larger electrodes delivered a stable voltage and power output. When combining electrode pairs with dimensions below the critical width in closely-spaced interdigitated electrode structures, the voltage instability could be overcome by the increased electrode area, while at the same time the small electrode widths and inter-electrode gaps permitted reduction of the ohmic cell resistance.

Furthermore, the use of closely-spaced electrodes can create problems during fuel cell operation. Reactant gases and reaction products from one electrode can easily migrate to the opposite electrode and destabilize the oxygen partial pressure and therefore the OCV and overall cell performance. This undesired gas-phase transport was observed in [25] for anode-supported SC-SOFC stacks, where the rapid transport of partial oxidation products from the anode to the cathode of the adjacent cell led to a 
near-zero OCV. It was suggested that such intermixing and diffusion of reaction gases and products also reduces performance in SC-SOFCs with coplanar electrodes. A partition between anodes and cathodes located on the same side of the electrolyte was proposed to avoid intermixing and prevent voltage drops [187,188]. Turbulent flow and gas intermixing between closely-spaced micro-electrodes were considered to be at the origin of very low OCVs of only $0.35 \mathrm{~V}$ [189] and a low power output [190] for coplanar micro-electrode arrays. However, in a study with interdigitated micro-electrodes with gaps of $14 \mu \mathrm{m}$, OCVs over $0.7 \mathrm{~V}$ were measured, indicating that diffusion of $\mathrm{H}_{2}$ and $\mathrm{CO}$ from anode to cathode did not affect the cell voltage [103]. According to Jasinski [191], a laminar flow field is required for optimal functioning of SC-SOFCs with coplanar electrodes, and very closely-spaced electrodes $(<50 \mu \mathrm{m})$ could induce turbulent gas flow leading to low cell performance. Also, there is a minimal gap size of approximately $1 \mu \mathrm{m}$ [35]. For this inter-electrode distance and a potential difference of $1 \mathrm{~V}$ between anode and cathode, the electrical field would be $10^{6} \mathrm{~V} \cdot \mathrm{m}^{-1}$, which is close to the electric field leading to disruptive discharge or electrical breakdown $\left(3 \cdot 10^{6} \mathrm{~V} \cdot \mathrm{m}^{-1}\right.$ in air).

The coplanar electrode configuration with closely-spaced electrodes also seems to favor chemical interaction between anode and cathode materials during sintering [192]. Cells with LSM-based cathode showed a blackened anode and electrolyte after sintering, while cells with LSCF cathode did not exhibit such a color change. Interaction between LSM and YSZ as reported for dual-face SOFCs [193] was assumed to have additionally affected the adjacent anode in cells with coplanar electrodes. The black coloration was attributed to the presence of manganese which probably had diffused from cathode to anode through the electrolyte. Such chemical interaction could affect cell performance of SC-SOFCs with coplanar electrodes and should be considered when cell component materials are selected.

As previously observed for electrolyte-supported cells [139], anode thickness was found to affect the voltage stability of SC-SOFCs with coplanar electrodes [150]. The use of a $300 \mu \mathrm{m}$-thick Ni-rich anode layer $(80 \mathrm{wt} \% \mathrm{NiO}$ ) on top of a $20 \mu \mathrm{m}$ thick contact layer consisting of $55 \mathrm{wt} \% \mathrm{NiO}$ and $45 \mathrm{wt} \%$ YSZ enabled a stable OCV close to $1 \mathrm{~V}$ without any major fluctuations during $80 \mathrm{~h}$ of testing, whereas thinner anode layers caused significant voltage fluctuations. Nickel loss due to nickel volatilization reduced the stability of nickel-based anodes in methane-air mixtures [96], but thick anodes were less subject to degradation, and cell stability could be increased [148].

Electrode size also plays a role for the operation of SC-SOFCs with coplanar electrodes of the same material [171,194]. For both electrodes made of platinum, a difference in catalytic activity could be created by using a different size for the anode and cathode [171]. The larger electrode generally worked as the cathode. However, only a few distinct gas compositions allowed the generation of a voltage difference, and the measured OCVs were below $0.5 \mathrm{~V}$.

In his work on SC-SOFCs, Riess [14] argues that SC-SOFCs with coplanar electrodes do not function well because of long residence times of the gas mixture over the electrodes in the gas chamber and inhomogeneous current density distribution in the strip electrodes. The latter point can be combined with experimental observations, where Ni-anodes were found to turn white in the anode parts closest to the inter-electrode gap, due to microstructural changes resulting from enhanced nickel loss $[103,150,151]$. It was suggested that not the whole electrode surface area participated equally in the electrochemical reactions because of a longer conduction path of the remote electrode regions and 
increased ohmic cell resistance. The region of an electrode close to the next adjacent counter electrode is therefore believed to be principally involved in the energy generating reactions.

To date, only few publications are available on SC-SOFCs with coplanar electrodes. Most of them are feasibility or proof-of-concept studies and deal with fabrication techniques and effects of testing parameters, cell geometry and electrode size. However, as to what is really happening on and between the electrodes, almost no analyses have been conducted yet. The small size of the electrodes yields very low conversion rates of the reactant gases, making it difficult to detect differences between input and output gases by mass spectroscopy in order to identify occurring reactions. Also, there is little understanding of the actual conduction path of the oxygen ions in the electrolyte. In one study, the difference in catalytic activity between anode and cathode for ethane-air mixtures was investigated using mass spectroscopy [147]. Additionally, impedance analysis of the ohmic cell resistance due to different electrolyte materials and electrode gaps was performed. However, the studies were applied to rather big electrodes ( $1 \mathrm{~mm}$ gap and width) as compared to microscale electrode structures. Due to the lack of fundamental studies, models and appropriate characterization and fabrication techniques, the actual working principles of SC-SOFCs with coplanar electrodes are not yet fully understood.

\subsubsection{Testing conditions}

Among the different testing conditions, the effect of gas flow direction, gas composition and operating temperature on cell performance has mainly been studied. For cells with two parallel electrode lines being exposed to various gas flow directions, the highest OCV was obtained for parallel gas flow [180,184]. Oxygen consumption at the anode and reaction gas intermixing caused the lowest OCV for perpendicular gas flow with the anode being placed ahead in the gas stream. Slightly different results were obtained by Jacques-Bédard et al. [148,150]. Lowest performance was confirmed for a cell position with the anode being exposed first to the gas mixture. Enhanced oxygen consumption at the anode and an oxygen-lean gas mixture reaching the cathode caused a low OCV and hence performance. Oxygen-rich mixtures with $R_{\text {mix }} \approx 1$ could compensate for the partial reaction of oxygen at the anode and the composition change of the gas mixture, but positioning the cathode first in the incoming gas stream led to the highest power output. For a fuel cell stack composed of several pairs of anode and cathode lines, highest performance was achieved for parallel positioning, which least affected the gas composition. Using FEM modeling, perpendicular gas flow with the cathode being exposed first to the incoming gas mixture was confirmed to be most favorable for an increased power output [181-183].

The optimum gas mixture composition differs between studies depending on cell component materials, chamber design, temperature and reaction gases. For instance, for coplanar Ni-YSZ and LSM-based electrodes on YSZ electrolytes, the maximum OCV was observed in the vicinity of $R_{\text {mix }}=2$ with a significant voltage drop for $R_{\text {mix }}=0.5$ at $800{ }^{\circ} \mathrm{C}$ in methane-air mixtures [150]. Similar results were obtained for anode-supported cells [27].

For SC-SOFCs with coplanar electrodes composed of Ni-GDC-Pd anode and LSM-YSZ cathode on a YSZ electrolyte, testing at $850{ }^{\circ} \mathrm{C}$ in a methane-air mixture revealed an increase of the OCV with increasing $R_{\text {mix }}$ [184]. Low OCVs below $0.4 \mathrm{~V}$ were obtained at $R_{\text {mix }}=1$, whereas OCVs over $0.5 \mathrm{~V}$ could only be measured for higher $R_{\text {mix }}$, with a maximum at $R_{\text {mix }}=5$. For single electrode lines [185] 
and micro-electrode arrays [189], $R_{\text {mix }}=3.75$ was necessary for operation in methane-air mixtures at $900{ }^{\circ} \mathrm{C}$. However, such high $R_{\text {mix }}$ values are unsuitable for cell operation, as they favor carbon formation and restrain performance [50]. For methane-air mixtures containing $3 \% \mathrm{H}_{2} \mathrm{O}$ at $900{ }^{\circ} \mathrm{C}$, a range of $R_{\text {mix }}$ from 2.78 to 6.67 was confirmed to lead to superior cell performance, whereas the stoichiometric ratio $\left(R_{\mathrm{mix}}=2\right)$ for the partial oxidation of methane led to the highest OCV for dry reaction gas [180]. The explanation of the high $R_{\text {mix }}$ in the wet gas mixture was based on the occurrence of methane steam reforming.

In the case of interdigitated micro-electrodes, fuel-rich gas mixtures were found to improve the cell performance output, whereas oxygen-rich mixtures lowered the OCV by transporting more oxygen to the very thin anode $(2-3 \mu \mathrm{m})$ than it could convert [103].

The use of other fuels than methane was studied for operation at lower temperatures of 500-600 ${ }^{\circ} \mathrm{C}$ [147]. Among the different electrolyte materials studied, SDC showed a lower ohmic resistance and led to a higher power output than YSZ or LSGM electrolytes in combination with a Ni-SDC anode and a SSC cathode. Similar cell performance was measured for ethane, propane and butane as fuel, whereas the low catalytic activity of the anode for methane partial oxidation at the reduced operating temperatures caused very poor performance in methane-air mixtures. The addition of $\mathrm{PdO}$ to the anode was found to enhance the catalytic activity of the anode for the hydrocarbon partial oxidation.

Based on Dyer's mixed-reactant cell [38], operation of a SC-SOFC with coplanar electrodes at room temperature was reported by Nagata et al. [194]. Pt electrodes of different size and a gap of $0.5 \mathrm{~mm}$ on a pseudboehmite electrolyte enabled an OCV of $0.54 \mathrm{~V}$.

\subsubsection{Microfabrication techniques}

The use of closely-spaced small-scale electrodes points out the great potential of SC-SOFCs with coplanar electrodes for miniaturization and their possible application as small- and microscale power sources. However, it also imposes challenges on the fabrication of such small electrode dimensions. Standard photolithography based microfabrication techniques enable the precise creation of microscale patterns, but the difficulty lies in creating such patterns out of multicomponent ceramic materials and creating electrodes with a porous microstructure. Thus, there is a need to find suitable, alternative techniques with high versatility to fabricate electrode patterns of precise dimensions at the microscale, to fabricate different electrode geometries, to precisely deposit the electrodes on an exact position on the electrolyte substrate, to allow elevated deposition and fabrication rates, and finally to manufacture porous electrodes from ceramic materials.

Although thin-film deposition techniques and photolithography-based microfabrication are suggested in the literature, the fabrication and the testing of complete cells are still lacking. Thin-film technologies (e.g., spin-on techniques, plasma spraying, chemical vapor deposition, laser deposition, sputtering, evaporation and wet spray) are proposed to fabricate coplanar thin-film micro-electrodes with interdigitated, comblike or differently shaped electrodes [168]. The electrodes can either be formed by deposition of the electrode material in the desired shape or by filling trenches in the electrolyte or substrate with electrode material. An interdigitated pattern of sputtered Pt electrodes on a sputtered thin-film GDC electrolyte was reported [195], and photolithographic patterning of electrode 
thin films deposited by laser ablation was suggested for the fabrication of interdigitated electrode patterns with inter-electrode gaps of 10 to $50 \mu \mathrm{m}$ [196]. Standard photolithography and wet chemical etching were used to fabricate interdigitated LSCO cathodes from sputtered thin films [30,197]. Despite spacings and electrode widths of $50 \mu \mathrm{m}$, the technique has not been expanded yet to the fabrication of interdigitated patterns of both anode and cathode. Also, the technique yielded very dense electrodes, decreasing the number of TPBs for the electrochemical reactions. Photoresist molding of coplanar micro-electrode arrays on a radio-frequency sputtered GDC electrolyte resulted in inter-electrode distances and electrode widths of $20 \mu \mathrm{m}$ [172]. The smallest inter-electrode gap for a functional single-face SC-SOFC with two parallel electrode lines (electrode width of $15 \mu \mathrm{m}$ ) reported so far was $5 \mu \mathrm{m}$ and was achieved by thin-film deposition techniques and photolithographic patterning [186]. However, the electrodes were made of $\mathrm{Pt}$ and $\mathrm{Au}$ instead of conventional, cermet and/or ceramic-based SOFC materials. The cells could actually be tested, but showed poor performance.

The first SC-SOFCs with coplanar electrodes were fabricated by manually smearing electrode inks with a brush on the electrolyte surface [107]. This technique has been used by Hibino et al. ever since, but cells with inter-electrode gaps and electrode widths smaller than $0.5 \mathrm{~mm}$ were not fabricated. Screen printing with electrode masks [12,98,103,198] and tape casting [150] were then proposed as suitable fabrication techniques for SC-SOFCs with micro-electrodes. Minimum gap sizes of $0.3 \mathrm{~mm}$ [103] and $0.2 \mathrm{~mm}[12,150]$ with minimum electrode widths of $0.5 \mathrm{~mm}$ [150] were achieved. For further miniaturization and the creation of interdigitated micro-electrode patterns, different microfabrication techniques are however necessary, among which microfluidic lithography, micromolding and robotic direct-writing approaches are currently the principal fabrication methods reported in the literature.

A micro-patterning method based on polymer molds and vacuum-assisted infiltration enabled the fabrication of interdigitated electrodes with an inter-electrode distance of $50 \mu \mathrm{m}$ and a width of $100 \mu \mathrm{m}$ [189,199-201]. In contrast to thin-film fabrication techniques, this microfluidic lithography approach integrated colloidal processing of ceramics and thus had the advantage of enabling a better control of the electrode microstructures in a subsequent sintering step. Microchannels in the mold were filled with electrode material (LSM for the cathode and Ni-SDC for the anode) and formed the microscale electrode structure on the YSZ electrolyte substrate.

A similar approach, called micromolding in capillaries, was employed to fabricate SC-SOFCs with interdigitated, $100 \mu \mathrm{m}$ wide electrodes separated by gaps of only $14 \mu \mathrm{m}$ [103]. However, the technique led to low reproducibility, and incomplete filling of the mold channels with electrode material resulted in only a few interdigitated electrode lines.

Robot-controlled direct-write microfabrication consists of extruding suspensions (or inks) of the respective electrode material through a micronozzle and depositing electrode structures on the electrolyte substrate using a robot-controlled deposition apparatus. This technique was applied to the fabrication of SC-SOFCs with coplanar single and multiple, interdigitated electrode pairs of conventional SOFC materials [104,149,151,177,180,184,185,202-205]. Inter-electrode distances ranging from 255 to $783 \mu \mathrm{m}$ (electrode width of approximately $0.6 \mathrm{~mm}$ ) [180,185] and electrode widths from 93 to $1,380 \mu \mathrm{m}$ (inter-electrode gap of approximately $250 \mu \mathrm{m}$ ) [151] were reported for single electrode pairs. Interdigitated electrode structures were fabricated with average gaps of about $300 \mu \mathrm{m}$ (electrode width of $600 \mu \mathrm{m}$ [180] and $140 \mu \mathrm{m}$ [149,204]) and $114 \mu \mathrm{m}$ (electrode width 
of $260 \mu \mathrm{m})$ [151]. The direct-writing technique was also employed to create U-shaped micro-electrodes [184], curvilinear micro-electrodes of arbitrary complex 2D geometry (average inter-electrode distance of 434 to $487 \mu \mathrm{m}$, average electrode width of 229 to $263 \mu \mathrm{m}$ [177]) as well as cell stacks [151,203]. A drawback of the direct-writing method however is the reduced control of the electrode feature sizes resulting from spreading of the electrode inks on the electrolyte substrate when conventional electrode inks of Newtonian flow behavior are used [151,206]. Additionally, these inks lead to a lens-like cross-sectional electrode shape and a non-uniform cross-sectional thickness of the electrodes [177,206]. Viscoelastic, gel-like electrode inks have been reported to enable better shape retention of the deposited electrode structures as compared with Newtonian inks and led to improved control of the electrode dimensions [205].

\subsubsection{SC-SOFCs with interdigitated electrode designs}

The first SC-SOFC with coplanar micro-electrode arrays was fabricated and tested by Kim et al. [172] in 2005. The cell was composed of Ni-GDC anode and SSC cathode lines spaced apart by a $20 \mu \mathrm{m}$ gap on a GDC electrolyte. An OCV of $0.2 \mathrm{~V}$ and a maximum power density of $67 \mathrm{~mW} \cdot \mathrm{cm}^{-2}$ were measured in a methane-air mixture at $500{ }^{\circ} \mathrm{C}$.

An OCV of only $0.35 \mathrm{~V}$ was obtained for microarrays of Ni-SDC and LSM on YSZ (electrode gap of $50 \mu \mathrm{m}$ ) using methane as fuel [189]. At $900{ }^{\circ} \mathrm{C}$ and $R_{\text {mix }}=3.75$, the maximum power density was approximately $75 \mathrm{~mW} \cdot \mathrm{cm}^{-2}$. The low $\mathrm{OCV}$ was attributed to turbulent flow and gas intermixing between the closely-spaced electrodes, as well as methane consumption in undesired reactions. Operation at lower temperatures in propane-air mixtures with a SSC-SDC cathode did not yield any performance improvement [190]. In addition to gas intermixing between the interdigitated electrodes with gap sizes of $100 \mu \mathrm{m}$, phase decomposition of the cathode led to a power output of only $1.5 \mathrm{~mW} \cdot \mathrm{cm}^{-2}$ at $550{ }^{\circ} \mathrm{C}$.

OCVs over $0.8 \mathrm{~V}$ were achieved for combshaped Ni-SDC anodes and LSM cathodes on SDC and YSZ electrolytes [12]. OCV as well as power density were found to depend on the furnace temperature. While the OCV slightly decreased with increasing temperature from 550 to $700{ }^{\circ} \mathrm{C}$, the maximum power density increased, reaching $40 \mathrm{~mW} \cdot \mathrm{cm}^{-2}$ at $700{ }^{\circ} \mathrm{C}$ and $R_{\operatorname{mix}}=1$.

A dependence of the OCV on the number of electrode pairs was observed for Ni-GDC-Pd anodes and LSM(-GDC) cathodes on a YSZ electrolyte [180,185]. When the number of electrode pairs was increased from 1 to 8 , the OCV decreased from 0.8 to $0.4 \mathrm{~V}$. The OCV drop was attributed to an increased system complexity, where the intermixing of reaction products was enhanced and the oxygen partial pressure at the cathode was reduced. In the case of cells with two electrode pairs, this performance loss could be overcome by decreasing the distance between the two pairs [180]. Increasing the pair-to-pair distance to $8 \mathrm{~mm}$ led to a recovery in cell performance and finally the same OCV and maximum power density as for a single pair of electrodes.

In contrast to [180,185] where an increasing number of electrode pairs led to OCVs below $0.8 \mathrm{~V}$, an OCV of $0.8 \mathrm{~V}$ was obtained for an interdigitated electrode structure of 5 pairs of Ni-YSZ anode and LSM cathode lines on a YSZ electrolyte [149]. However, oscillations of the cell voltage between 0.4 and $0.8 \mathrm{~V}$ were observed during cell aging, probably due to $\mathrm{Ni}$ oxidation-reduction cycles and nickel volatilization. After $24 \mathrm{~h}$ under open circuit conditions, the maximum power density had dropped 
by $15 \%$, indicating cell instability issues. The short-term stability of the OCV of these cells was affected by the number of electrode lines and was found to improve with increasing number of electrode pairs [151].

The feasibility of SC-SOFCs with interdigitated micro-electrodes was also shown by comparing the performance of macro, milli and micro SC-SOFCs [103]. Micro SC-SOFCs with interdigitated electrodes separated by gaps of only $14 \mu \mathrm{m}$ were successfully operated in methane-air mixtures at $650{ }^{\circ} \mathrm{C}$, delivering a maximum power density of $17 \mathrm{~mW} \cdot \mathrm{cm}^{-2}$. Compared to macro and milli cells, the reduction of the inter-electrode gap as well as the increased number of anode-cathode pairs connected in parallel in the interdigitated pattern of the micro cell maximized the usable cell surface area and enabled a ten-times higher power density.

\subsubsection{SC-SOFCs with arbitrary electrode designs}

Within investigations on the influence of the gas flow direction, a new electrode configuration with a U-shaped electrode encompassing the other electrode was proposed [184]. A U-shaped cathode encountering the gas mixture ahead of the anode gave stable cell operation during two-day operation with an OCV of about $0.7 \mathrm{~V}$. With the anode encountering the gas feed first, a significant degradation of cell performance was stated. The OCV was only $0.1 \mathrm{~V}$ and no current could be drawn from the cell. When placing the anode ahead of the cathode, reaction products carried from anode to cathode were made responsible for a decrease of the oxygen partial pressure gradient between the two electrodes and therefore the OCV.

SC-SOFCs with curvilinear micro-electrodes of arbitrary complex 2D geometry were studied by Kuhn et al. [177]. For comparable electrode width, inter-electrode gap and electrode surface area, two cells with different electrode shapes exhibited peak power densities of $2.3 \mathrm{~mW} \cdot \mathrm{cm}^{-2}$, indicating that electrode shape did not significantly affect cell performance. In addition, as previously observed for the interdigitated electrode configuration [149], complexity of electrode geometry did not reduce the OCV, but a stable OCV of $0.9 \mathrm{~V}$ was obtained.

\subsubsection{Cell stacks}

In his patent on SC-SOFCs with coplanar electrodes, Louis et al. [36] discussed the possibility of series connection of single cells on the same electrolyte substrate. Different connecting approaches were proposed such as electrically connecting adjacent electrodes of each cell pair, depositing electrodes on alternately arranged stripes of electrolyte and interconnect, or bridging the gap between electrodes of one cell by an electrolyte layer and the gap between adjacent cells by overlaying interconnect material. Different possibilities of series and parallel connection of SC-SOFCs with coplanar electrodes are also discussed in [203,207-209].

The series and parallel connection of two unit cells on the same electrolyte substrate was experimentally demonstrated by Hibino et al. [174]. Series connection of two cells doubled the measured OCV, whereas parallel connection led to a twice as high maximum current as compared to a single cell. An electrode configuration composed of several electrode lines arranged in a comblike, interdigitated manner was proposed to maximize the electrode area and create closely-spaced electrodes $[110,147,174]$. A stack assembly of such electrode structures being connected in series and 
in parallel was patented in 1996 [210]. Another stack design consisted of a thin-film electrolyte applied on both sides of an alumina support, followed by deposition of alternating anode and cathode bars on top of the electrolyte [211].

Connecting single cells in stacks can lead to a significant increase in cell performance [150,151]. A stack of two sets of electrodes connected in parallel on the same electrolyte substrate was shown to double the power output as compared to the single cell, whereas the power could be doubled further by increasing the number of electrodes to three sets [150]. However, the use of cell stacks did not improve the OCV stability of cells with microscale electrode widths [151].

\subsubsection{Summary of SC-SOFCs with coplanar electrodes}

Tables 4 and 5 summarize fabrication technique, electrode width and gap size, cell component materials, operating parameters and performance of SC-SOFCs with coplanar electrodes. If cell performance was measured under different testing conditions, the highest cell performance and corresponding testing parameters reported in the reference are listed in the following tables.

\subsection{Micro-tubular SC-SOFCs and other cell configurations}

The operation of micro-tubular SOFCs in fuel-air mixtures was recently proposed by Akhtar et al. [91]. The tubular cell configuration already provides an intrinsically sealless cell design; therefore, the main advantage of single-chamber operation consists of the simplification of gas manifolding in cell stacks and miniaturized cells. Tubular SOFCs are known to enable rapid start-ups and exhibit improved shock resistance for practical applications. However, their main disadvantages are high fabrication costs and low power densities resulting from long current paths in contrast to planar SOFCs [212]. Under single-chamber operating conditions, micro-tubular SC-SOFCs seem to enable higher fuel utilization and cell efficiencies compared to other SC-SOFC cell configurations as the tubular cell design may improve mass transport and impede gas intermixing between anode and cathode [91].

Akhtar et al. [91] studied the effects of different operating conditions on the cell performance of anode-supported micro-tubular SC-SOFCs in methane-air mixtures. The cells were composed of conventional SOFC materials with a Ni-YSZ anode, YSZ electrolyte and LSM cathode. Cell initialization was found to be most efficient when reducing the $\mathrm{NiO}$ anode in hydrogen. During cell operation, a mixing ratio of $R_{\text {mix }}=1$ and a furnace temperature of $750{ }^{\circ} \mathrm{C}$ were identified to yield the highest current densities, and a peak power density of $122 \mathrm{~mW} \cdot \mathrm{cm}^{-2}$ was measured under these operating conditions. Similar to planar SC-SOFCs, cell performance increased with increasing gas flow rate. However, the gas flow rates used in [91] for the micro-tubular cells were significantly lower than the ones reported for planar SC-SOFCs and might explain the higher fuel utilization and cell efficiency.

A new, three-dimensional (3D) cell design for SC-SOFCs was proposed by Koh et al. [213]. The 3D cells were composed of periodic, interconnected channels separated by anode/electrolyte/cathode walls. Such a design has the advantage of integrated gas flow channels in a compact 3D cell structure and an increased volumetric surface area for higher power densities. However, electrochemical testing of the device has not been reported yet. 
Table 4. Summary of SC-SOFCs with one pair of coplanar electrodes.

\begin{tabular}{|c|c|c|c|c|c|c|c|c|c|c|c|}
\hline Ref. & Year & $\begin{array}{c}\text { Fabrication } \\
\text { technique }\end{array}$ & $\begin{array}{l}\text { Gap size } d \\
\quad(\mathrm{~mm})\end{array}$ & $\begin{array}{c}\text { Electrode } \\
\text { width } w \\
(\mathrm{~mm})\end{array}$ & Electrolyte & Anode & Cathode & $\begin{array}{c}T_{\text {furnace }} \\
\left({ }^{\circ} \mathrm{C}\right)\end{array}$ & $\underset{\text { mixture }}{\text { Gas }}$ & $\begin{array}{c}\text { OCV } \\
(\mathrm{V})\end{array}$ & $\begin{array}{c}P_{\max } \text { or } I_{\max } \\
\text { (for smallest } d \text { and } w \text { ) }\end{array}$ \\
\hline$[36]$ & 1981 & Painted* & $0.3-0.4$ & 0.5 & Alumina & $\mathrm{Pt}-\mathrm{Al}_{2} \mathrm{O}_{3}$ & $\mathrm{SrRuO}_{3}-\mathrm{Al}_{2} \mathrm{O}_{3}$ & 21 & $\mathrm{H}_{2}-\mathrm{O}_{2}-\mathrm{N}_{2}$ & 0.67 & $3 \mu \mathrm{A}$ \\
\hline [107] & 1995 & Smeared* & $0.5-5$ & & $\mathrm{BaCe}_{0.8} \mathrm{Gd}_{0.2} \mathrm{O}_{3-\alpha}$ & $\mathrm{Pd}$ & $\mathrm{Au}$ & 950 & $\begin{array}{l}\mathrm{CH}_{4} \text {-air } \\
R_{\text {mix }}=2\end{array}$ & 0.7 & $24 \mathrm{~mA}$ \\
\hline [174] & 1996 & Smeared* & $0.5-5$ & $1-4$ & $\mathrm{BaCe}_{0.8} \mathrm{Gd}_{0.2} \mathrm{O}_{3-\alpha}$ & $\mathrm{Pd}$ & $\mathrm{Au}$ & 950 & $\begin{array}{l}\mathrm{CH}_{4} \text {-air } \\
R_{\text {mix }}=2 \\
\end{array}$ & 0.7 & $24 \mathrm{~mA}$ \\
\hline [69] & 2000 & Smeared* & $1-4$ & & YSZ & Ni-GDC & LSM-MnO ${ }_{2}$ & 950 & $\begin{array}{l}\mathrm{CH}_{4} \text {-air } \\
R_{\text {mix }}=1\end{array}$ & 0.8 & $102 \mathrm{~mW} \cdot \mathrm{cm}^{-2}$ \\
\hline [117] & 2000 & Smeared* & $0.5-3$ & & YSZ- $\mathrm{MnO}_{2}$ & Ni-GDC & LSM-MnO ${ }_{2}$ & 950 & $\begin{array}{l}\mathrm{CH}_{4} \text {-air } \\
R_{\text {mix }}=1 \\
\end{array}$ & 0.8 & $143 \mathrm{~mW} \cdot \mathrm{cm}^{-2}$ \\
\hline [137] & 2001 & Smeared* & 0.5 & & YSZ & $\mathrm{Ni}$ & LSM & 950 & $\mathrm{CH}_{4}$-air & 0.8 & $140 \mathrm{~mW} \cdot \mathrm{cm}^{-2}$ \\
\hline [147] & 2002 & Smeared* & $0.5-3$ & $0.5-1$ & SDC & Ni-SDC-PdO & $\mathrm{SSC}$ & 600 & $\begin{array}{l}\mathrm{C}_{4} \mathrm{H}_{10} \text {-air } \\
R_{\text {mix }}=0.6 \\
\end{array}$ & 0.8 & $245 \mathrm{~mW} \cdot \mathrm{cm}^{-2}$ \\
\hline [147] & 2002 & Smeared* & 1 & 1 & YSZ & Ni-SDC & $\mathrm{SSC}$ & 600 & $\begin{array}{c}\mathrm{C}_{2} \mathrm{H}_{6} \text {-air } \\
R_{\text {mix }}=1.1\end{array}$ & 0.97 & $20 \mathrm{~mW} \cdot \mathrm{cm}^{-2}$ \\
\hline [147] & 2002 & Smeared* & 1 & 1 & LSGM & Ni-SDC & SSC & 600 & $\begin{array}{c}\mathrm{C}_{2} \mathrm{H}_{6} \text {-air } \\
R_{\text {mix }}=1.1 \\
\end{array}$ & 0.92 & $50 \mathrm{~mW} \cdot \mathrm{cm}^{-2}$ \\
\hline [98] & 2005 & $\begin{array}{l}\text { Screen- } \\
\text { printing }\end{array}$ & 1 & 6 & YSZ & Ni-YSZ & LSM & 800 & $\begin{array}{c}\mathrm{CH}_{4} \text {-air } \\
R_{\text {mix }}=1.5 \\
\end{array}$ & 0.6 & $1.2 \mathrm{~mW} \cdot \mathrm{cm}^{-2}$ \\
\hline [198] & 2006 & $\begin{array}{l}\text { Screen- } \\
\text { printing }\end{array}$ & 1 & 6 & YSZ & Ni-YSZ & LSM & 770 & $\begin{array}{l}\mathrm{CH}_{4} \text {-air } \\
R_{\text {mix }}=2 \\
\end{array}$ & 0.5 & $1 \mathrm{~mW} \cdot \mathrm{cm}^{-2}$ \\
\hline [198] & 2006 & $\begin{array}{l}\text { Screen- } \\
\text { printing }\end{array}$ & 2 & 1 & YSZ & Ni-YSZ & LSM & 760 & $\begin{array}{l}\mathrm{CH}_{4} \text {-air } \\
R_{\text {mix }}=2 \\
\end{array}$ & 0.6 & $1 \mathrm{~mW} \cdot \mathrm{cm}^{-2}$ \\
\hline
\end{tabular}


Table 4. Cont.

\begin{tabular}{|c|c|c|c|c|c|c|c|c|c|c|c|}
\hline Ref. & Year & $\begin{array}{c}\text { Fabrication } \\
\text { technique }\end{array}$ & $\begin{array}{l}\text { Gap size } d \\
(\mathrm{~mm})\end{array}$ & $\begin{array}{c}\text { Electrode } \\
\text { width } w \\
(\mathrm{~mm})\end{array}$ & Electrolyte & Anode & Cathode & $\begin{array}{l}T_{\text {furnace }} \\
\left({ }^{\circ} \mathbf{C}\right)\end{array}$ & $\begin{array}{c}\text { Gas } \\
\text { mixture }\end{array}$ & $\begin{array}{l}\text { OCV } \\
(\mathrm{V})\end{array}$ & $\begin{array}{c}P_{\max } \text { or } I_{\max } \\
\text { (for smallest } d \text { and } w \text { ) }\end{array}$ \\
\hline$[184,185]$ & 2006 & $\begin{array}{l}\text { Direct- } \\
\text { writing }\end{array}$ & $0.255-0.783$ & 0.6 & YSZ & Ni-GDC-Pd & LSM & 900 & $\begin{array}{c}\mathrm{CH}_{4} \text {-air } \\
R_{\text {mix }}=3.75 \\
\end{array}$ & 0.8 & $101 \mathrm{~mW} \cdot \mathrm{cm}^{-2}$ \\
\hline$[180]$ & 2007 & $\begin{array}{l}\text { Direct- } \\
\text { writing }\end{array}$ & $0.255-0.783$ & 0.6 & YSZ & Ni-GDC-Pd & $\begin{array}{l}\text { LSM- } \\
\text { GDC }\end{array}$ & 900 & $\begin{array}{c}\mathrm{CH}_{4} \text {-air }+ \\
3 \% \mathrm{H}_{2} \mathrm{O} \\
R_{\text {mix }}=3.75\end{array}$ & 0.8 & $101 \mathrm{~mW} \cdot \mathrm{cm}^{-2}$ \\
\hline$[150]$ & 2007 & $\begin{array}{c}\text { Tape } \\
\text { casting }\end{array}$ & $0.2-1$ & $0.5-4$ & YSZ & Ni-YSZ & LSM & 800 & $\begin{array}{l}\mathrm{CH}_{4} \text {-air } \\
R_{\text {mix }}=2 \\
\end{array}$ & 0.9 & $40 \mathrm{~mW} \cdot \mathrm{cm}^{-2}$ \\
\hline$[103]$ & 2007 & $\begin{array}{l}\text { Screen- } \\
\text { printing }\end{array}$ & 1.2 & 0.5 & GDC & Ni-GDC & $\mathrm{SSC}$ & 600 & $\begin{array}{c}\mathrm{CH}_{4} \text {-air } \\
R_{\text {mix }}=3.2\end{array}$ & 0.8 & $1.5 \mathrm{~mW} \cdot \mathrm{cm}^{-2}$ \\
\hline$[186]$ & 2007 & $\begin{array}{l}\text { Sputtering, } \\
\text { lithography }\end{array}$ & 0.005 & 0.015 & YSZ & $\mathrm{Pt}$ & $\mathrm{Au}$ & 400 & $\begin{array}{l}\mathrm{CH}_{4} \text {-air } \\
R_{\text {mix }}=1 \\
\end{array}$ & 0.38 & \\
\hline$[171]$ & 2008 & Smeared* & $1-1.2$ & 1 & $\begin{array}{l}\text { YSZ } \\
\text { SDC }\end{array}$ & $\mathrm{Pt}$ & $\begin{array}{c}\mathrm{Pt} \\
\mathrm{LSM} \\
\end{array}$ & $600-1,000$ & $\mathrm{H}_{2}-\mathrm{O}_{2}$ & $0-0.7$ & \\
\hline [194] & 2008 & & 0.5 & & $\mathrm{Al}_{2} \mathrm{O}_{3}$ & $\mathrm{Pt}$ & $\mathrm{Pt}$ & Room T & $\mathrm{H}_{2}-\mathrm{O}_{2}$ & 0.54 & \\
\hline$[151]$ & 2009 & $\begin{array}{l}\text { Direct- } \\
\text { writing }\end{array}$ & 0.25 & $0.093-1.38$ & YSZ & Ni-YSZ & LSM & 700 & $\begin{array}{l}\mathrm{CH}_{4} \text {-air } \\
R_{\text {mix }}=2\end{array}$ & 0.898 & $10.5 \mathrm{~mW} \cdot \mathrm{cm}^{-2}$ \\
\hline
\end{tabular}

*painted/smeared: electrode slurries or pastes were painted/smeared on the electrolyte 
Table 5. Summary of SC-SOFCs with coplanar, interdigitated, comb-like electrodes.

\begin{tabular}{|c|c|c|c|c|c|c|c|c|c|c|c|}
\hline Ref. & Year & $\begin{array}{l}\text { Fabrication } \\
\text { technique }\end{array}$ & $\begin{array}{l}\text { Gap size } \\
d(\mathrm{~mm})\end{array}$ & $\begin{array}{c}\text { Electrode } \\
\text { width } w \\
(\mathbf{m m})\end{array}$ & Electrolyte & Anode & Cathode & $\begin{array}{c}T_{\text {furnace }} \\
\left({ }^{\circ} \mathrm{C}\right)\end{array}$ & $\begin{array}{l}\text { Gas } \\
\text { mixture }\end{array}$ & $\begin{array}{c}\text { OCV } \\
(\mathrm{V})\end{array}$ & $\underset{\left(\mathrm{mW} \cdot \mathrm{cm}^{-2}\right)}{P_{\max }}$ \\
\hline$[172]$ & 2005 & $\begin{array}{l}\text { Photoresist } \\
\text { molding }\end{array}$ & 0.02 & 0.02 & GDC & Ni-GDC & $\mathrm{SSC}$ & 500 & $\mathrm{CH}_{4}$-air & 0.2 & 67 \\
\hline [12] & 2006 & Screen-printing & 0.5 & & $\mathrm{SDC}$ & Ni-SDC & LSM & 700 & $\begin{array}{l}\mathrm{CH}_{4} \text {-air } \\
R_{\text {mix }}=1\end{array}$ & 0.8 & 40 \\
\hline$[12]$ & 2006 & Screen-printing & 0.5 & & YSZ & Ni-SDC & LSM & 700 & $\begin{array}{l}\mathrm{CH}_{4} \text {-air } \\
R_{\text {mix }}=1\end{array}$ & 0.9 & \\
\hline$[189]$ & 2006 & $\begin{array}{l}\text { Microfluidic } \\
\text { lithography }\end{array}$ & 0.05 & 0.1 & YSZ & $\mathrm{Ni}-\mathrm{SDC}$ & LSM & 900 & $\begin{array}{c}\mathrm{CH}_{4} \text {-air } \\
R_{\text {mix }}=3.75\end{array}$ & 0.35 & 75 \\
\hline$[180,185]$ & 2007 & Direct-writing & 0.3 & 0.6 & YSZ & Ni-GDC-Pd & LSM-GDC & 900 & $\begin{array}{c}\mathrm{CH}_{4} \text {-air } \\
R_{\text {mix }}=3.75\end{array}$ & $\begin{array}{l}0.43- \\
0.65\end{array}$ & $12-15$ \\
\hline$[190]$ & 2007 & $\begin{array}{l}\text { Microfluidic } \\
\text { lithography }\end{array}$ & 0.1 & 0.1 & $\mathrm{SDC}$ & $\mathrm{Ni}-\mathrm{SDC}$ & SSC-SDC & 550 & $\begin{array}{c}\mathrm{C}_{3} \mathrm{H}_{8} \text {-air } \\
R_{\text {mix }}=0.7\end{array}$ & 0.67 & 1.5 \\
\hline$[103]$ & 2007 & Screen printing & 0.3 & 1.2 & $\mathrm{CGO}$ & $\mathrm{Ni}-\mathrm{CGO}$ & $\mathrm{SSC}$ & 650 & $\begin{array}{c}\mathrm{CH}_{4} \text {-air } \\
R_{\text {mix }}=1.5\end{array}$ & 0.75 & 1.5 \\
\hline$[103]$ & 2007 & $\begin{array}{l}\text { Micromolding in } \\
\text { capillaries }\end{array}$ & 0.014 & 0.1 & $\mathrm{CGO}$ & $\mathrm{Ni}-\mathrm{CGO}$ & $\mathrm{SSC}$ & 650 & $\begin{array}{l}\mathrm{CH}_{4} \text {-air } \\
R_{\text {mix }}=2\end{array}$ & 0.77 & 17 \\
\hline$[149]$ & 2008 & $\begin{array}{l}\text { Direct- } \\
\text { writing }\end{array}$ & 0.517 & $0.13-0.32$ & YSZ & Ni-YSZ & LSM & 700 & $\begin{array}{l}\mathrm{CH}_{4} \text {-air } \\
R_{\text {mix }}=2\end{array}$ & 0.8 & 1.3 \\
\hline$[192]$ & 2009 & $\begin{array}{l}\text { Direct- } \\
\text { writing }\end{array}$ & 0.3 & 0.38 & YSZ & Ni-YSZ & LSM-YSZ & 700 & $\begin{array}{l}\mathrm{CH}_{4} \text {-air } \\
R_{\text {mix }}=2\end{array}$ & 0.73 & 0.7 \\
\hline$[151]$ & 2009 & $\begin{array}{l}\text { Direct- } \\
\text { writing }\end{array}$ & 0.114 & 0.26 & YSZ & Ni-YSZ & LSM & 700 & $\begin{array}{l}\mathrm{CH}_{4} \text {-air } \\
R_{\text {mix }}=2\end{array}$ & 0.8 & \\
\hline
\end{tabular}




\section{Modeling of SC-SOFCs}

Numerical models have the advantage of predicting fuel cell performance and examining separately and independently effects of various parameters. They permit interpretation of experimental results and can give guidelines for design and performance optimization. While literature on experimental studies on SC-SOFCs is relatively abundant, only few references can be found on modeling.

\subsection{Simulation of planar anode-supported SC-SOFCs}

Hao et al. [161,214-216] proposed a two-dimensional numerical model to simulate the performance of planar anode-supported SC-SOFCs for various geometries, operating conditions and hydrocarbon fuels. The model was composed of several submodels that considered the coupled effects of gas flow (velocity, temperature and gas species distribution) around the cell, heat transfer, reactions and species transport in the porous electrodes, heterogeneous chemistry (partial oxidation and steam reforming reactions), electrochemical reactions at the electrode-electrolyte interface and mixed conductivity of the electrolyte. The simulations were based on a Ni-YSZ |SDC(or YSZ) $\mid$ BSCF-SDC cell for which data from electrochemical testing in a methane-air mixture were used to calibrate and validate the model [161]. The simulated cell performance revealed an increase in power density with temperature and the occurrence of concentration losses at high current densities. At $750{ }^{\circ} \mathrm{C}$, the highest power density was obtained for $R_{\text {mix }}=1.65$ [161] and 1.67 [216]. For lower $R_{\text {mix }}$, full fuel oxidation reduced the amount of available hydrogen whereas at higher $R_{\text {mix }}$ the oxygen partial pressure at the cathode was very low. Performance simulations as a function of cell orientation confirmed experimental results from the literature that measured higher performance for cells with the cathode being exposed first to the incoming gas stream [161]. Due to higher ionic conductivity, cells with SDC electrolytes were found to enable higher peak power densities as compared to cells with YSZ [216]. Cell efficiency and fuel utilization were very low, only 2.5 and $22 \%$ respectively, but could be doubled by adding two more cells in series. Best efficiency was obtained at $710{ }^{\circ} \mathrm{C}$ for SDC and $790{ }^{\circ} \mathrm{C}$ for YSZ while temperatures above $525{ }^{\circ} \mathrm{C}$ were necessary to enable the catalytic reactions and yield non-zero cell efficiency. Non-isothermal simulations [161] were used to evaluate the effect of anode thickness on power output and the cell performance was highest for $200 \mu \mathrm{m}$ thick anodes.

A three-dimensional model was developed by Akhtar et al. [73,217] to simulate the flow dynamics and electrochemical performance of planar anode-supported SC-SOFCs. For simplification, hydrogenair mixtures were used, thereby neglecting that the working principle of SC-SOFCs is based on the selectivity of the anode for hydrocarbon partial oxidation. Additionally, various reasons, such as safety issues, were given why hydrogen-air mixtures are not practicable in SC-SOFCs. The model was based on the coupled effects of gas chamber, porous electrodes and ideally selective electrochemical reactions in electrode catalyst layers. The effect of cell orientation with respect to the fuel-air mixture was studied by simulating the evolution of reactant $\left(\mathrm{H}_{2}\right.$ and $\left.\mathrm{O}_{2}\right)$ and reaction product $\left(\mathrm{H}_{2} \mathrm{O}\right)$ concentrations over the cell length as well as gas velocity profiles within the cell [217]. Although a parallel configuration enabled improved gas flow, the consumption of reactants was found to be more effective in cells orientated perpendicular to the gas flow, especially with the cathode being exposed first to the incoming gas mixture. For the perpendicular cell orientation with anode first [73], an 
increase in electrode porosity led to improved hydrodynamic flow but lower reactant utilization. The use of a porous electrolyte was therefore suggested for improved gas flow [73] while electrodes with fine pores enabled enhanced reactant conversion due to longer residence time of the gases in the electrode and more available catalyst sites [217]. Due to the hydrodynamics, cell stacks should preferably be constructed in a parallel cell arrangement or additional supply of the reactants should be considered for the downstream cells [73].

\subsection{Numerical study of reaction mechanisms in SC-SOFCs}

Hao et al. [218,219] used their numerical model to study the heterogeneous reaction mechanisms within a Ni-YSZ anode under single-chamber operating conditions. It was found that hydrogen was formed by internal reforming of methane within the anode rather than by partial oxidation. A three-layer structure of the anodic catalytic reactions was identified, decomposing the anode into a zone of total combustion of methane and hydrogen close to the electrode-gas interface, followed by an internal reforming zone and finally a water-gas shift reaction region close to the interface with the electrolyte. Oxygen was calculated to be quickly and almost completely depleted by total combustion within the first few microns of the anode, thus eliminating partial oxidation in the remaining anode thickness. The combustion reactions in the outer anode layer generated heat for the endothermic reforming reactions in the underlying layer. The model was also used to simulate performance of cells with multi-layer anodes [219]. A 3\% increase in peak power could be obtained when applying a platinum layer on the nickel anode.

\subsection{Efficiency calculations for SC-SOFCs}

Efficiency calculations by Hao et al. [89] predicted maximum efficiencies above $10 \%$ for single cells operated under single-chamber conditions, and the low values reported in the literature were attributed to the lack of electrode selectivity and non-optimized gas flow management. Simulations showed that both efficiency and fuel utilization decreased with increasing methane flow rate and accompanying amount of unreacted fuel. Nonetheless, even low fuel flow rates did not significantly increase efficiency. Decreasing $R_{\text {mix }}$ to oxygen-rich gas mixtures enabled higher fuel utilization at low flow rates whereas at higher flow rates efficiency and fuel utilization decreased with increasing oxygen content in the gas mixture due to enhanced parasitic reactions. However, at high flow rates, the reaction gas could easily access all parts of the cell in the gas stream resulting in a higher power output while at low flow rates depletion of reaction gas along the cell length reduced the cell power. In order to enable higher efficiency and at the same time high power densities, a two-cell stack configuration was suggested. For a single cell, increasing the chamber width, orienting the cell perpendicular to the gas stream or increasing the cell length did not yield any improvement, but no alternative approaches for optimizing chamber design and gas flow management were proposed. The necessity for further improving electrode selectivity was however emphasized as only $20 \%$ of the fuel were found to be converted into useful electrical power whereas the remaining fuel was consumed in parasitic reactions or left the chamber unreacted. 


\subsection{Performance modeling of planar electrolyte-supported SC-SOFCs}

Shiratori et al. [220,221] calculated performance characteristics of planar electrolyte-supported SC-SOFCs for operation in $\mathrm{H}_{2}-\mathrm{O}_{2}$ mixtures at $950{ }^{\circ} \mathrm{C}$. The calculated values for cell voltage and power output were found to fit previous experimental results by Hibino et al. In order to simulate the operating characteristics of several series connected single cells in a stack, a single cell was separated into two segments of varying length. The separation led to a twice as high OCV as for the single cell. The highest performance with reduced electrode overpotentials and ohmic loss was obtained for a cell with two equally-sized segments.

\subsection{Thermodynamic considerations of SC-SOFCs}

Thermodynamic modeling of fuel-air mixtures can be employed to determine the influence of temperature and gas mixture composition on the OCV $[50,79,90]$. Based on Equation (6), the OCV depends on the oxygen partial pressure at anode and cathode. Assuming a perfect anode catalyst, the oxygen partial pressure at the anode corresponds to the gas composition of the reacted fuel-air mixture. For an infinite reaction rate at the anode, the gas mixture will react to an equilibrium gas composition, which can be calculated using a thermodynamic database. As an example, the oxygen partial pressure at the anode is given as a function of temperature for different methane-air mixtures in Figure 10 and is shown to increase with increasing temperature and decreasing $R_{\text {mix }}$.

Figure 10. Oxygen partial pressure at the anode as a function of temperature for different methane-air gas mixture compositions.

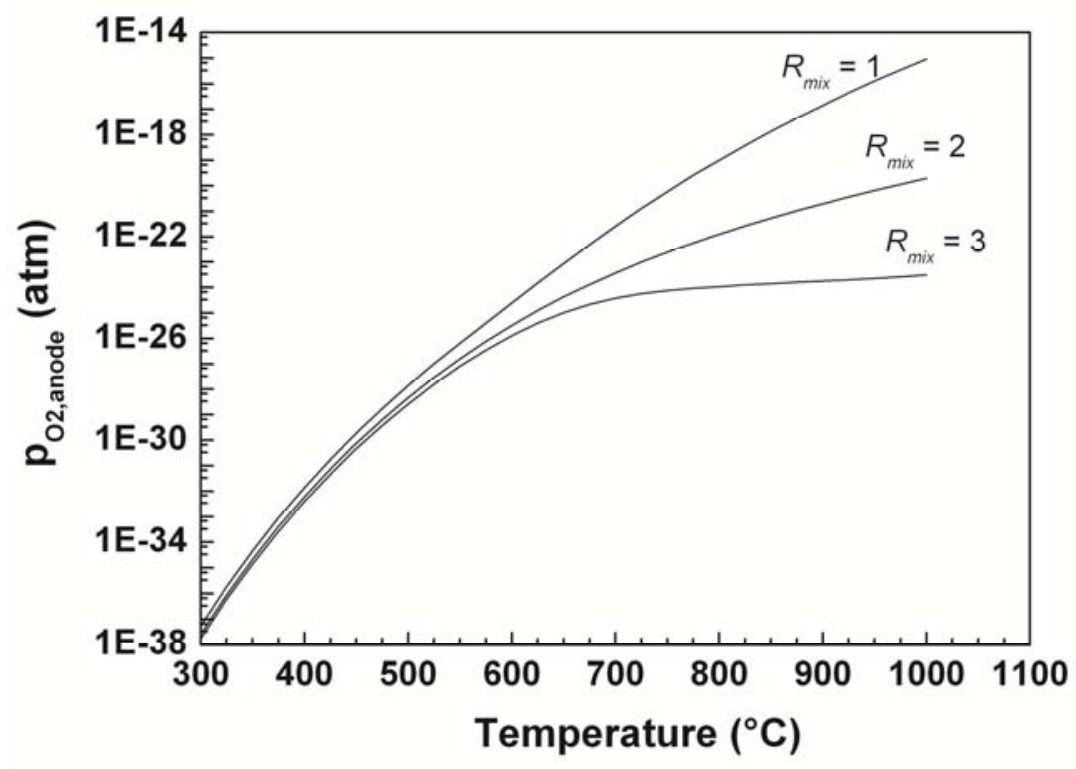

Assuming that the cathode is inert towards the fuel reactions, the oxygen partial pressure at the cathode side corresponds to the initial $\mathrm{O}_{2}$ content in the gas mixture [50]. The OCV can then be calculated according to Equation (6) and is given in Figure 11 as a function of $R_{\operatorname{mix}}$ at $700{ }^{\circ} \mathrm{C}$. The OCVs obtained based on thermodynamic equilibrium calculations $[50,90]$ were higher than OCVs 
from experimental studies. This difference can be attributed to non-ideally selective electrodes in reality and to temperature changes resulting from exothermic reactions [50].

The equilibrium concentrations of the species in the gas phase were calculated by Buergler et al. [50] as a function of temperature for a fixed methane-to-oxygen ratio and for varying $R_{\text {mix }}$ at a constant temperature. The main components of the equilibrium gas phase at the anode-electrolyte interface were $\mathrm{CH}_{4}, \mathrm{CO}_{2}, \mathrm{CO}, \mathrm{H}_{2} \mathrm{O}, \mathrm{H}_{2}$ and $\mathrm{N}_{2}$. For different $R_{\text {mix }}, \mathrm{H}_{2}$ and $\mathrm{CO}$ were the primary products at temperatures above $800{ }^{\circ} \mathrm{C}$ whereas at lower temperatures $\mathrm{H}_{2} \mathrm{O}$ and $\mathrm{CO}_{2}$ were predominant. Similar results were obtained for the thermodynamic calculation of the equilibrium composition of propane-air mixtures where the threshold temperature was $733{ }^{\circ} \mathrm{C}[79]$.

Figure 11. Open circuit voltage obtained from equilibrium gas calculations as a function of $R_{\text {mix }}$ at $700{ }^{\circ} \mathrm{C}$ for methane-air mixtures.

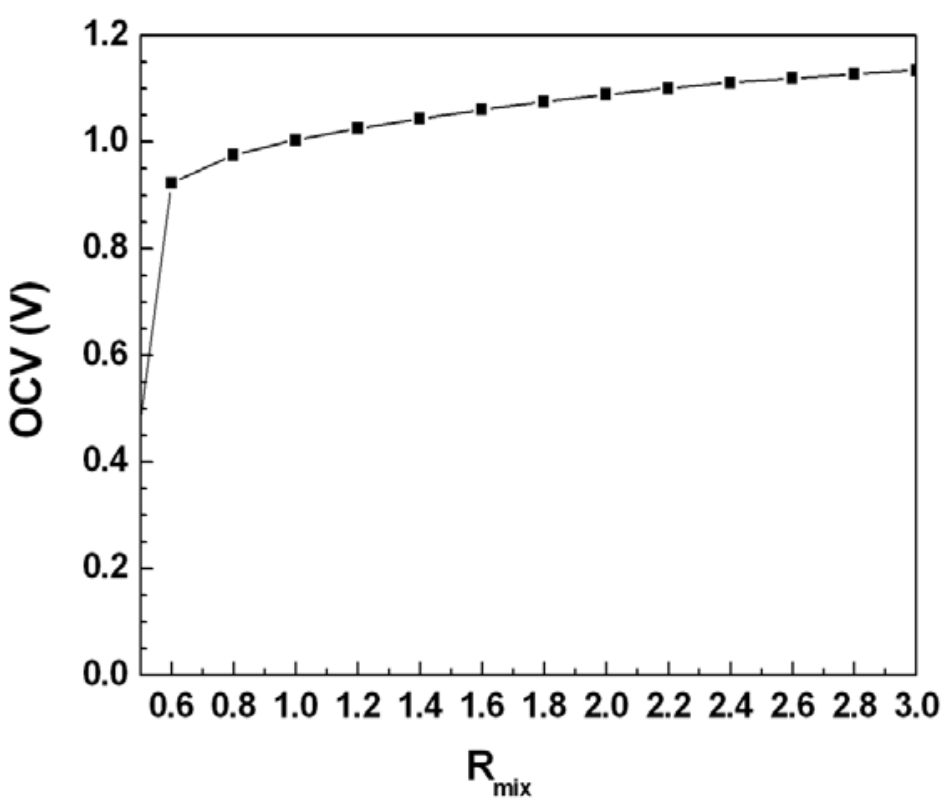

Although high concentrations of syngas are beneficial to enable higher power outputs, elevated operating temperatures are not suitable for SC-SOFC operation as cathode materials can easily become active for fuel reactions. Additionally, at lower temperatures, a lower oxygen partial pressure at the anode (see Figure 10) can be obtained in favor of higher OCVs. Therefore, an intermediate operating temperature was recommended as a compromise between a low oxygen partial pressure at the anode and elevated amounts of syngas [50]. Calculating the composition of the equilibrium gas as a function of $R_{\text {mix }}$ revealed an increase of the amounts of $\mathrm{H}_{2} \mathrm{O}$ and $\mathrm{CO}_{2}$ with decreasing $R_{\text {mix }}$. A maximum was obtained for $R_{\text {mix }}=0.5$ which corresponds to the stoechiometric composition for the full oxidation of methane. For $R_{\text {mix }}$ below 0.5 , almost no $\mathrm{CO}$ and $\mathrm{H}_{2}$ were present in the equilibrium gas, and an increased oxygen partial pressure could induce nickel reoxidation. Carbon deposition was calculated to occur at low temperatures $\left(<700{ }^{\circ} \mathrm{C}\right)$ or elevated $R_{\text {mix }}(>2)$. Although adding small amounts of water shifted the carbon formation to higher $R_{\text {mix }}$, moisture can affect the oxygen partial pressure and reduce the OCV. Unreacted $\mathrm{CH}_{4}$ was found in all equilibrium gas phases, but its amount decreased with increasing temperature. Comparison between the outlet gases of real SC-SOFC systems and the 
calculated equilibrium gas composition revealed more unreacted methane and lower amounts of $\mathrm{H}_{2}$ and $\mathrm{CO}$ in the experimental work. This indicates that equilibrium is not reached during SC-SOFC operation.

\subsection{Performance studies of SC-SOFCs with coplanar electrodes}

The influence of electrode and electrolyte dimensions on the performance of SC-SOFCs with coplanar electrodes was discussed by Fleig et al. [173]. The cell design consisted of closely-spaced electrode thin films on thin film electrolytes. The geometrical requirements for electrodes and electrolyte were evaluated based on equivalent circuit models of the cell component resistances. An interdigitated electrode structure with electrode distances of a few microns $(2-12 \mu \mathrm{m})$ and electrode widths in the order of 6 to $10 \mu \mathrm{m}$ was found to yield sufficiently low polarization resistances. However, such small distances might cause problems during operation as reaction products could very easily diffuse from anode to cathode. Therefore, thick film electrolytes $(>1 \mu \mathrm{m})$ could be used instead of very small electrode distances. In addition to the geometrical constraints, the cell resistance was influenced by the electrode reaction resistance. Mixed conductive thin film cathodes could be used that exhibit elevated rates for oxygen reduction and incorporation into the oxide lattice whereas micro-structuring of thin film nickel anodes could create pore sizes in the order of $100 \mathrm{~nm}$ to ensure low polarization resistance.

Chung et al. [181-183] simulated the electrochemical performance of a SC-SOFC with two coplanar parallel electrode lines on a GDC electrolyte using a finite element macro modeling scheme. Ideally selective electrodes were assumed, that is, the fuel oxidation takes only place at the Ni-GDC anode and the oxygen reduction only at the SSC-SDC cathode. The cell performance was evaluated for operation at $500^{\circ} \mathrm{C}$ in a hydrogen-air mixture, thereby neglecting the fact that SC-SOFC operation is based on the partial oxidation of hydrocarbon fuels. The simulated E-I characteristic showed that ohmic losses due to oxygen ion diffusion were the major source of voltage loss whereas concentration losses were negligible. Additionally, the effect of cell dimension and gas flow direction was simulated. An increase in electrode thickness from 10 to $80 \mu \mathrm{m}$ did not significantly affect the power output. However, a narrow interdistance between the electrodes $(10 \mu \mathrm{m}$ instead of 20, 40 and $80 \mu \mathrm{m})$ and a thicker electrolyte ( $80 \mu \mathrm{m}$ instead of 10, 20 and $40 \mu \mathrm{m}$ ) were found to enable higher cell performance, and a peak power density of $100 \mathrm{~mW} \cdot \mathrm{cm}^{-2}$ was calculated for the optimized cell geometry. These results also emphasized the fact that thicker, mechanically strong electrolytes serving as cell support can be used in single-face SC-SOFCs without negative impact on cell performance. A perpendicular gas flow with the cathode being first exposed to the gas mixture was identified to be most favorable for increased power density, confirming experimental results [150]. Parallel gas flow let to enhanced concentration losses.

\section{Applications}

The low cell efficiency remains one of the main obstacles for the practical implementation of SC-SOFCs. Potential applications should therefore benefit from the intrinsic features and properties of these cells, that is, the seal-free cell design, cell operation in fuel-air gas mixtures at elevated temperatures, possible rapid start-ups as well as their capacity for heat generation and hydrocarbon 
reforming. The compact and flexible designs enable the fabrication of a wide variety of geometries, sizes and shapes for different kinds of applications.

Applications of SC-SOFCs might include rapid low-temperature start-up batteries for electric vehicles [93] and micropower applications in portable electronics [25,203]. Without the need for reactant gas separation, SC-SOFCs could work as gas, temperature or pressure sensors $[123,175]$ in mixed gas conditions or in harsh industrial environments where gas mixtures at elevated temperatures are present. They could be placed as-fabricated inside gas tubes or chimneys by exposing the electrodes directly to the gas mixtures without any need for packaging design. Miniaturized SC-SOFCs $\left(<1 \mathrm{~cm}^{2}\right)$ are proposed for integration with MEMS systems, systems-on-a-chip designs and Si-based microelectronics $[29,168]$. Cells could be fabricated on the same silicon chip and directly power the adjacent electronic microdevices. Due to the heat release during single-chamber operation, SC-SOFCs can be used for cogeneration or bottoming cycles [91,92]. Combined with conventional SOFCs, the generated heat from the SC-SOFC could be used to preheat gas streams or maintain the temperature of the conventional cell. Additionally, the SC-SOFC could be employed as a hydrocarbon reforming system for the conventional cell or for cogeneration of electrical power and chemicals. The syngas of $\mathrm{H}_{2}$ and $\mathrm{CO}$ could e.g. be used for methanol fabrication [111]. Energy harvesting applications such as power generation from exhaust gases of heat engines in cars [222] or motorcycles [142,143] are also envisaged, as the low efficiency of SC-SOFCs can be compensated by the generation of electrical power from waste gases. Several examples of possible applications are detailed in the following sections.

\subsection{Microsystems and portable power applications}

Due to the seal-free cell design, SC-SOFCs exhibit increased thermal shock resistance and enable rapid start-up, making them interesting for portable and small-scale power applications. Additionally, the heat generated from the exothermic fuel reactions can be used to thermally self-sustain the cells whereas thermal management and heat supply issues limit the applicability of conventional SOFCs in portable power applications. The thermally self-sustaining miniature SC-SOFC by Shao et al. $[25,223,224]$ enabled rapid start up from cold start to stable power in less than $1 \mathrm{~min}$. The generated cell voltage and power output of a two-cell stack was sufficient to power a $1.5 \mathrm{~V}$ MP3 player. Thermal cycling had no negative effect on the cell performance or mechanical integrity of the system. As cell start up was initiated by first heating the cell in a furnace, combining the SC-SOFC with a spiral Swiss roll heat exchanger and combustor was proposed as a thermally self-sustaining, integrated electrical power generation device without the need for an external heat source $[159,160,164]$.

Wei et al. powered a USB fan using a four-cell SC-SOFC stack with a total active area of only $1 \mathrm{~cm}^{2}$ [167]. The fan was operated at a working voltage of $2.73 \mathrm{~V}$, and stable short-term operation was possible with multiple switching on and off of the fan.

However, the low efficiency of the SC-SOFCs still imposes a severe technical hurdle to the practical use of these cells as battery replacements in portable power applications $[25,167]$. 


\subsection{Energy harvesting applications}

SC-SOFCs have been proposed to generate electrical power from automotive exhaust gases $[142,143,222]$. The high temperature of the exhaust gases provides sufficient heat for fuel cell operation, while different hydrocarbon fuels and oxygen are available in the exhaust gas stream. The cell can be simply put inside the exhaust pipe, as demonstrated by the Hibino group [142,143]. A twelve-cell SC-SOFC stack delivered OCVs of 5-8 V and a power output of $1 \mathrm{~W}$ in the exhaust gas of a motorcycle. Performance studies of a single cell under modeled exhaust gases identified optimal operating conditions for a cell temperature of $800{ }^{\circ} \mathrm{C}$ or less and for a ratio of all present hydrocarbons to oxygen corresponding to the stoichiometric composition of the gas mixture for the partial oxidation of the hydrocarbons. These conditions were very close to the ones of the real motorcycle exhaust. Thermal cycling and mechanical damage did not affect cell performance, emphasizing the advantages of seal-free SC-SOFCs. Elevated gas flows as present in engine exhaust systems enabled high OCVs because of reduced catalytic activity of the cathode for hydrocarbon oxidation and reduced gas transport of reaction products from anode to cathode. The energy generated from the engine exhaust gas streams could be used to supply auxiliary power units. This energy harvesting application could additionally be expanded to electricity generation from housing and industrial exhaust gases.

\subsection{Sensor applications}

The difference in catalytic activity between anode and cathode for the fuel can be used in sensor technology for the detection of fuel gas in gas streams, gas mixtures or air as well as the control of fuel concentrations [123,175]. In a combined fuel cell-sensor system the fuel cell could deliver electrical power to adjust fuel fluctuations detected by the sensor part [123].

Tomita et al. presented a $\mathrm{H}_{2}$-gas sensor operating in the single-chamber mode at a temperature of $30{ }^{\circ} \mathrm{C}$ [175]. Cells were fabricated from a proton-conducting $\mathrm{Sn}_{0.9} \mathrm{In}_{0.1} \mathrm{P}_{2} \mathrm{O}_{7}$ electrolyte and $\mathrm{Pt} / \mathrm{C}$ and $\mathrm{C}$ electrodes. Both planar cells with anode and cathode situated on opposite sides of the electrolyte and cells with coplanar electrodes on the same side of the electrolyte showed a change in the OCV when hydrogen was present in the oxygen gas.

To continuously provide low power to MEMS systems, capacitors or sensors in unsupervised, secluded applications, a closed-cycle microscale power generating device was proposed by Peterson et al. [19]. By splitting water, a radiolytic source provides hydrogen and oxygen to an alkaline single-chamber micro fuel cell which in return produces an electrical power output and returns water to the radiolytic source. The whole power generating device could be integrated into a miniaturized package of about $1 \mathrm{~cm}^{3}$ and deliver power in the $\mathrm{mW}$ range. This concept might also be applicable to SC-SOFCs.

\subsection{System design for practical applications}

System design and stack fabrication for practical applications have been addressed in a variety of recent patents on SC-SOFC technology. A stack design of vertically arranged single cell SC-SOFCs at fixed distances inside a mixed-gas chamber [225] and a venturi system for uniform mixing of fuel and 
oxidant gases [226] were proposed. For the fabrication of electrolyte- and electrode-supported SC-SOFC stacks, Hewlett-Packard Company [227] presented a mechanical/chemical polishing or planarization method. A laminated single-chamber fuel cell stack was patented by Toyota Motor Corporation [228]. Motorola Inc. [229] suggested an improved portable fuel cell device operating on a mixture of fuel and oxidant gases. The device was composed of fuel and oxidant reservoir, gas lines, fuel cell and exhaust gas processing unit. The advantage of the Motorola device was the caption and adsorption of water vapor by a water trap in the exhaust gas processing unit. A dry exhaust gas can then be emitted, avoiding release of water onto the fuel cell powered device and user.

The majority of patents on cell fabrication, stack design and efficient gas supply were issued to the Dainippon Printing Company. In [230], the fabrication of a thin-film SC-SOFC on a supporting substrate with gas feedholes was proposed while the effect of cell component thickness on cell performance was discussed in [231]. Hydrogen separation layers in porous interconnects were suggested for the separated supply of fuel to the anode of a SC-SOFC within the mixed gas stream so that parasitic reactions could be limited [232]. For improved gas circulation and utilization, ejected gases could be remixed with fresh fuel and oxygen and be reinjected into the fuel cell system [233] after removal of $\mathrm{CO}$ and $\mathrm{CO}_{2}$ [234]. In order to avoid short circuits between anode and cathode of adjacent cells in cell stacks, the anode of a single cell could be completely covered and surrounded by electrolyte material [235]. A compact stack design was proposed where two single cells with anode-electrolyte-cathode three-layer structure are stacked one on top of the other, separated by a porous, electrically conductive substrate [236]. Several of these stacks can further be connected in parallel as the reaction gases reach the electrodes of the successively arranged cell blocks through the porous substrate. Single cells could also be attached at both of the ends of a porous substrate [237] or SC-SOFC stacks can be assembled by connecting single cells in parallel between two conductive substrates [238]. To enhance durability and enable connection with single cells on opposite sides of a substrate, communicating holes could be introduced through substrate and single cell [239]. Jigs could be used to accommodate single cells housed in a SC-SOFC stack [240,241], and single cells could be fitted into a support with buffered recesses for absorption of vibration and dimension differences [242]. A SOFC stack with anodes and cathodes arranged on opposite sides of the electrolyte substrate was described in [243]. The anodes were placed near the fuel inlet to increase gas supply efficiency. The latter could also be improved by using interconnectors with through-holes and combined gas flow channels [244], and an insulating electrolyte can be applied to avoid short circuits via the through-holes [245]. Catalytically active through-holes leading to the fuel electrode [246], modified electrode catalyst layers [247], direct gas supply and removal to and from the air electrode [248] and improved gas manifolding between the two electrodes [249] were proposed to enhance fuel utilization and improve cell performance.

\section{Summary}

Since the first experimental demonstration of a SC-SOFC delivering a significant current in the early 1990s by Hibino et al., growing interest in SC-SOFCs has been manifested by an increasing number of publications over the years. Planar electrolyte- and anode-supported SC-SOFCs are the two classical cell designs where progress in research has enabled cell performances similar to conventional 
dual-chamber SOFCs. Due to the use of a single, sealing-free gas chamber and operation in a gas mixture, fully-porous cells and SC-SOFCs in a single-face configuration with both electrodes situated on the same side of the electrolyte were demonstrated. Low fuel utilization and cell efficiency are still the main drawback of SC-SOFCs, and future efforts will have to focus on improving selectivity of electrode materials to make SC-SOFCs a competitive power generating device.

\section{References and Notes}

1. Priestnall, M.A.; Kotzeva, V.P.; Fish, D.J.; Nilsson, E.M. Compact mixed-reactant fuel cells. J. Power Sources 2002, 106, 21-30.

2. Chen, S.-Z.; Dong, X.-F.; Lin, W.-M. Research progress on single-chamber solid oxide fuel cell. Dianyuan Jishu 2003, 27, 134-136.

3. Wei, B.; Lu, Z.; Huang, X.Q.; Liu, Z.G.; Al, G.; Su, W.H. Recent advances in single chamber solid oxide fuel cells. Dianyuan Jishu 2006, 30, 243-246.

4. Buergler, B. E. Single Chamber Solid Oxide Fuel Cells. Ph.D. thesis, ETH, Zurich, Switzerland, 2006.

5. Yano, M.; Tomita, A.; Sano, M.; Hibino, T. Recent advances in single-chamber solid oxide fuel cells: A review. Solid State Ionics 2007, 177, 3351-3359.

6. Hibino, T.; Wang, S.; Kakimoto, S.; Sano, M. Single chamber solid oxide fuel cell constructed from an yttria-stabilized zirconia electrolyte. Electrochem. Solid-State Lett. 1999, 2, 317-319.

7. Bay, L.; Horita, T.; Sakai, N.; Ishikawa, M.; Yamaji, K.; Yokokawa, H. Hydrogen solubility in Pr-doped and un-doped YSZ for a one chamber fuel cell. Solid State Ionics 1998, 113-115, 363-367.

8. Asano, K.; Hibino, T.; Iwahara, H. SOFC for chemical cogeneration using fuel-air mixed gas. In Proceedings of ECS Transactions - 4th International Symposium on Solid Oxide Fuel Cells, Yokohama, Japan, June, 1995; pp. 58-66.

9. Vo, N.X.P.; Yoon, S.P.; Nam, S.W.; Han, J.; Lim, T.H.; Hong, S.A. Fabrication of an anode-supported SOFC with a sol-gel coating method for a mixed-gas fuel cell. Key Eng. Mater. 2005, 277-279, 455-462.

10. Raz, S.; Jak, M.J.G.; Schoonman, J.; Riess, I. Supported mixed-gas fuel cells. Solid State Ionics 2002, 149, 335-341.

11. Riess, I. The significance of impeded reactions in solid state electrochemistry. Solid State Ionics 2005, 176, 1667-1674.

12. Yoon, S.P.; Kim, H.J.; Park, B.T.; Nam, S.W.; Han, J.; Lim, T.H.; Hong, S.A. Mixed-fuels fuel cell running on methane-air mixture. J. Fuel Cell Sci. Technol. 2006, 3, 83-86.

13. Shukla, A.K.; Raman, R.K.; Scott, K. Advances in mixed-reactant fuel cells. Fuel Cells 2005, 4, 436-447.

14. Riess, I. On the single chamber solid oxide fuel cells. J. Power Sources 2008, 175, 325-337.

15. Hibino, T.; Kakimoto, S. Separator Free Single Chamber Solid Electrolyte Fuel Cell and Its Manufacture. Japanese Patent JP2002280015A, 2002.

16. Goedickemeier, M.; Nussbaum, D.; Kleinlogel, C.; Gauckler, L.J. Solid oxide fuel cells with reaction-selective electrodes. In Proceedings of the 192nd Meeting of the Electrochemical Society, Paris, France, August, 1997; pp. 2562.

17. Grueneberg, G. Electrochemical conversion of nuclear energy. In Fuel Cells: Modern Processes For The Electrochemical Production Of Energy; Vielstich, W., Ives, D.J.G., Eds.; Wiley-Interscience: New York, USA, 1965; pp. 374-376.

18. Meng, H.; Wu, M.; Hu, X.X.; Nie, M.; Wei, Z.D.; Shen, P.K. Selective cathode catalysts for mixed-reactant alkaline alcohol fuel cells. Fuel Cells 2006, 6, 447-450. 
19. Peterson, R.B.; Paul, B.K.; Palmer, T.; Wu, Q.; Jost, W.; Tseng, C.H.T.; Tiwari, S.; Patello, G.; Buck, E.C.; Holladay, J.D.; Shimskey, R.; Humble, P.; MacFarlan, P.; Wainright, J. Radiolytic microscale power generation based on single chamber fuel cell operation. J. Micromech. Microeng. 2007, 17, S250-S256.

20. Barton, S.C.; Deng, W.; Gallaway, J.; Levendovsky, S.; Olson, T.S.; Atanassov, P.; Sorkin, M.; Kaufman, A.; Gibbard, H.F. Mixed-feed direct methanol fuel cell: Materials and design solutions. ECS Trans. 2006, 1, 315-322

21. Gallaway, J.; Deng, W.; Barton, S.C.; Levendosky, S.; Olson, T.S.; Atanassov, P.; Sorkin, M.; Kaufman, A.; Gibbard, H.F. Mixed-feed direct methanol fuel cell: materials and design solution. In Proceedings of The Electrochemical Society 208th ECS Meeting, Los Angeles, CA, USA, October, 2005; pp. 1849.

22. Barton, S.C.; Patterson, T.; Wang, E.; Fuller, T.F.; West, A.C. Mixed-reactant, strip-cell direct methanol fuel cells. J. Power Sources 2001, 96, 329-336.

23. Scott, K.; Shukla, A.K.; Jackson, C.L.; Meuleman, W.R.A. A mixed-reactants solid-polymerelectrolyte direct methanol fuel cell. J. Power Sources 2004, 126, 67-75.

24. Cheng, S.; Liu, H.; Logan, B. E. Power densities using different cathode catalysts (Pt and CoTMPP) and polymer binders (Nafion and PTFE) in single chamber microbial fuel cells. Environ. Sci. Technol. 2006, 40, 364-369.

25. Shao, Z.; Haile, S.M.; Ahn, J.; Ronney, P.D.; Zhan, Z.; Barnett, S.A. A thermally self-sustained micro solid-oxide fuel-cell stack with high power density. Nature 2005, 435, 795-798.

26. Napporn, T.; Morin, F.; Meunier, M. Evaluation of the actual working temperature of a single-chamber SOFC. Electrochem. Solid-State Lett. 2004, 7, A60-A62.

27. Napporn, T.W.; Jacques-Bedard, X.; Morin, F.; Meunier, M. Operating conditions of a single-chamber SOFC. J. Electrochem. Soc. 2004, 151, A2088-A2094.

28. Suzuki, T.; Jasinski, P.; Petrovsky, V.; Anderson, H.U.; Dogan, F. Anode supported single chamber solid oxide fuel cell in CH4-air mixture. J. Electrochem. Soc. 2004, 151, A1473-A1476.

29. Tuller, H.L. Integration of solid state ionics and electronics: sensors and power sources. $J$. Ceram. Soc. Jpn. 2004, 112, S1093-S1098.

30. Bieberle-Huetter, A.; Tuller, H. Fabrication and structural characterization of interdigitated thin film La(1-x)SrxCoO3 (LSCO) electrodes. J. Electroceram. 2006, 16, 151-157.

31. Rosenblum, L.; English, R.E. Nuclear-electric systems in space. In Proceedings of Advance Energy Sources and Conversion Techniques, Pasadena, CA, USA, 1958; pp. 243-253.

32. Grueneberg, G.; Wicke, W.; Justi, E. Generation of electrical energy. British Patent GB994448, 1961.

33. Grimes, P.G.; Fiedler, B.; Adam, J. Liquid alkaline fuel cells. In Proceedings of the 15th Power Sources Conference, Session on Primary Fuel Cell Batteries, Fort Monmouth, N.J., USA, 1961; pp. 29-32.

34. Eyraud, C.; Lenoir, J.; Gery, M. Fuel cells using electrochemical properties of adsorbents - Piles a combustibles utilisant les proprietes electrochimiques des adsorbats. Acad. Sci. - C. R. 1961, 252, 1599-1600.

35. van Gool, W. The possible use of surface migration in fuel cells and heterogeneous catalysis. Philips Res. Rep. 1965, 20, 81-93.

36. Louis, G.A.; Lee, J.M.; Maricle, D.L.; Trocciola, J.C. Solid electrolyte electrochemical cell. US Patent US4248941A, 1981.

37. Pool, R. Electricity by serendipity. Science 1990, 247, 1034-1035.

38. Dyer, C.K. A novel thin-film electrochemical device for energy conversion. Nature 1990, 343, 547-548.

39. Dyer, C.K. Primary source of electrical energy using a mixture of fuel and oxidizer. US Patent 4,863,813, 1989.

40. Taylor, T.M. Efficiency enhancement for solid-electrolyte fuel cell. US Patent US005102750A, 1992. 
41. Dyer, C.K. Compact fuel cell and continuous process for making the cell. US Patent US004988582A, 1991.

42. Dyer, C.K. Modular fuel cell assembly. US Patent 5,094,928, 1992.

43. Gottesfeld, S. Thin-film fuel cells. Nature 1990, 345, 673.

44. Mallouk, T.E. Miniaturized Electrochemistry. Nature 1990, 343, 515.

45. Moseley, P. Sensing reducing gases. Nature 1990, 346, 23.

46. Ellgen, P.C. Devices providing electrical energy from fuel/oxygen mixtures. US Patent US005162166A, 1992.

47. Wang, D.Y.; Kennedy, D.T.; MacAllister, B.W. Method and device for gaseous fuel cell operation. US Patent US005100742A, 1992.

48. Hibino, T.; Iwahara, H. Simplification of solid oxide fuel cell systems using partial oxidation of methane. Chem. Lett. 1993, 7, 1131-1134.

49. Minh, N.Q.; Takahashi, T. Science and Technology of Ceramic Fuel Cells; Elsevier: Amsterdam, Netherlands, 1995.

50. Buergler, B.E.; Grundy, A.N.; Gauckler, L.J. Thermodynamic equilibrium of single-chamber SOFC relevant methane-air mixtures. J. Electrochem. Soc. 2006, 153, A1378-A1385.

51. Kordesch, K.; Simader, G. Fuel Cells and Their Applications; VCH: Weinheim, Germany, 1996.

52. Hibino, T.; Hashimoto, A.; Inoue, T.; Tokuno, J.I.; Yoshida, S.I.; Sano, M. A low-operatingtemperature solid oxide fuel cell in hydrocarbon-air mixtures. Science 2000, 288, 2031-2033.

53. Jasinski, P.; Suzuki, T.; Byars, Z.; Dogan, F.; Anderson, H.U. Comparison of anode and electrolyte support configuration of single-chamber SOFC. In Proceedings of ECS Transactions: 8th International Symposium on Solid Oxide Fuel Cells, Paris, France, April/May 2003; pp. 1101-1108.

54. Shao, Z.; Kwak, C.; Haile, S.M. Anode-supported thin-film fuel cells operated in a single chamber configuration 2T-I-12. Solid State Ionics 2004, 175, 39-46.

55. Hibino, T.; Hashimoto, A.; Inoue, T.; Tokuno, J.I.; Yoshida, S.I.; Sano, M. Single-chamber solid oxide fuel cells at intermediate temperatures with various hydrocarbon-air mixtures. J. Electrochem. Soc. 2000, 147, 2888-2892.

56. Yano, M.; Kawai, T.; Okamoto, K.; Nagao, M.; Sano, M.; Tomita, A.; Hibino, T. Single-chamber SOFCs using dimethyl ether and ethanol. J. Electrochem. Soc. 2007, 154, B865-B870.

57. Morel, B.; Roberge, R.; Savoie, S.; Napporn, T.; Meunier, M. Catalytic activity and performance of LSM cathode materials in single chamber SOFC. Appl. Catal., A 2007, 323, 181-187.

58. Ashcroft, A.T.; Cheetham, A.K.; Foord, J.S.; Green, M.H.; Grey, C.P.; et al. Selective oxidation of methane to synthesis gas using transition metal catalysts. Nature 1990, 344, 319.

59. Torniainen, P.M.; Chu, X.; Schmidt, L.D. Comparison of monolith-supported metals for the direct oxidation of methane to syngas. J. Catal. 1994, 146, 1-10.

60. Dissanayake, D.; Rosynek, M.P.; Kharas, K.C.C.; Lunsford, J.H. Partial oxidation of methane to carbon monoxide and hydrogen over a Ni/ $/ \mathrm{Al}_{2} \mathrm{O}_{3}$ catalyst. J. Catal. 1991, 132, 117-127.

61. Peters, K.; Rudolf, M.; Voetter, H. Ueber den Reaktionsverlauf der Methanspaltung. Brennstoff-Chemie 1955, 36, 257-266.

62. Wheeler, C.; Jhalani, A.; Klein, E.J.; Tummala, S.; Schmidt, L.D. The water-gas-shift reaction at short contact times. J. Catal. 2004, 223, 191-199.

63. Tulenin, Y.P.; Sinev, M.Y.; Savkin, V.V.; Korchak, V.N. Dynamic behaviour of Ni-containing catalysts during partial oxidation of methane to synthesis gas. Catal. Today 2004, 91, 155-159.

64. Zhang, X.; Hayward, D.O.; Mingos, D.M.P. Further studies on oscillations over nickel wires during the partial oxidation of methane. Catal. Lett. 2003, 86, 235-243.

65. Ishihara, T.; Takita, Y. Partial oxidation of methane into syngas with oxygen permeating ceramic membrane reactors. Catal. Surv. Jpn. 2001, 4, 125-133.

66. Choudhary, V.R.; Rane, V.H.; Rajput, A.M. Selective oxidation of methane to $\mathrm{CO}$ and $\mathrm{H}_{2}$ over unreduced NiO-rare earth oxide catalysts. Catal. Lett. 1993, 22, 289-297. 
67. Hibino, T.; Hashimoto, A.; Asano, K.; Yano, M.; Suzuki, M.; Sano, M. An intermediatetemperature solid oxide fuel cell providing higher performance with hydrocarbons than with hydrogen. Electrochem. Solid-State Lett. 2002, 5, A242-A244.

68. Asano, K.; Hibino, T.; Iwahara, H. A novel solid oxide fuel cell system using the partial oxidation of methane. J. Electrochem. Soc. 1995, 142, 3241-3245.

69. Hibino, T.; Wang, S.; Kakimoto, S.; Sano, M. One-chamber solid oxide fuel cell constructed from a YSZ electrolyte with a Ni anode and LSM cathode. Solid State Ionics 2000, 127, 89-98.

70. Riess, I.; van der Put, P.J.; Schoonman, J. Solid oxide fuel cells operating on uniform mixtures of fuel and air. Solid State Ionics 1995, 82, 1-4.

71. Riess, I. Significance of impeded reactions in solid state electrochemistry-Conspicuous examples. Solid State Ionics 2006, 177, 1591-1596.

72. Kellogg, I.D.; Koylu, U.O.; Petrovsky, V.; Dogan, F. Effectiveness of anode in a solid oxide fuel cell with hydrogen/oxygen mixed gases. Int. J. Hydrogen Energy 2009, 34, 5138-5143.

73. Akhtar, N.; Decent, S. P.; Loghin, D.; Kendall, K. A three-dimensional numerical model of a single-chamber solid oxide fuel cell. Int. J. Hydrogen Energy 2009, 34, 8645-8663.

74. Kellogg, I.D.; Dogan, F.; Petrovsky, V.; Koylu, U.O. Performance of single-chamber SOFC using hydrogen/air mixed-gas fuels. Mater. Sci. Technol. 2006, 1, 371-377.

75. Kellogg, I.D.; Koylu, U.O.; Petrovsky, V.; Dogan, F. Thermodynamic modeling and testing of the $\mathrm{H}_{2} / \mathrm{O} 2 / \mathrm{Ni} / \mathrm{NiO}$ system. Mater. Sci. Technol. 2007, 2, 1168-1174.

76. Napporn, T.W.; Savoie, S.; Roberge, R.; Jacques-Bedard, X.; Meunier, M. Single-chamber SOFC: comparing dry and humidified conditions. In Proceedings of the Electrochemical Society-Solid oxide fuel cells IX, Quebec, CA, January, 2005; pp. 371-377.

77. Demin, A.K.; Gulbis, F.Y. Efficiency of air-methane mixture fed SOFC. In Proceedings of the 9th CIMTEC-World Forum on New Materials, Symposium VII - Innovative Materials in Advanced Energy Technologies, Florence, Italy, June, 1998; pp.15-21.

78. Kellogg, I.D.; Dogan, F.; Suzuki, T.; Koylu, U.O.; Anderson, H.U.; Petrovsky, V. Single-chamber SOFC operating with hydrocarbon-air and hydrogen-oxygen gas mixtures. ECS Trans. 2007, 7, 971-980.

79. Zhan, Z.; Liu, J.; Barnett, S.A. Operation of anode-supported solid oxide fuel cells on propane-air fuel mixtures. Appl. Catal., A 2004, 262, 255-259.

80. Hibino, T.; Hashimoto, A.; Yano, M.; Suzuki, M.; Yoshida, S.I.; Sano, M. High performance anodes for SOFCs operating in methane-air mixture at reduced temperatures. J. Electrochem. Soc. 2002, 149, A133-A136.

81. Cabezas, M.D.; Lamas, D.G.; Bellino, M.G.; Fuentes, R.O.; Walsoe De Reca, N.E.; Larrondo, S.A. Catalytic Behavior of PdONiOSDC composites for partial oxidation of methane: Application as anodes of single-chamber IT-SOFCs. Electrochem. Solid-State Lett. 2009, 12, 34-37.

82. Demin, A.K.; Gulbis, F.Y. Zirconia-based SOFC with non-noble electrodes fed by air-methane mixture. Solid State Ionics 2000, 135, 451-456.

83. Zhang, C.; Sun, L.; Ran, R.; Shao, Z. Activation of a single-chamber solid oxide fuel cell by a simple catalyst-assisted in-situ process Electrochem. Commun. 2009, 11, 1563-1566.

84. Ahn, K.; Kim, H.; Chung, Y.C.; Son, J.W.; Lee, H.W.; Lee, J.H. Catalytic characteristics of perovskite-type oxides under mixed methane and oxygen gases. J. Korean Ceram. Soc. 2008, 45, 232-237.

85. Fisher, J.C.; Chuang, S.S.C. Investigating the CH4 reaction pathway on a novel LSCF anode catalyst in the SOFC. Catal. Commun. 2009, 10, 772-776.

86. Hartley, A.; Sahibzada, M.; Weston, M.; Metcalfe, I.; Mantzavinos, D. La0.6Sr0.4Co0.2Fe0.8O3 as the anode and cathode for intermediate temperature solid oxide fuel cells. Catal. Today 2000, 55, 197-204.

87. Suzuki, T.; Jasinski, P.; Petrovsky, V.; Anderson, H.U.; Dogan, F. Performance of a porous electrolyte in single-chamber SOFCs. J. Electrochem. Soc. 2005, 152, A527-A531. 
88. Liu, M.; Lu, Z.; Wei, B.; Zhu, R.; Huang, X.; Chen, K.; A, G.; Su, W. Anode-supported micro-SOFC stacks operated under single-chamber conditions. J. Electrochem. Soc. 2007, 154, B588-B592.

89. Hao, Y.; Goodwin, D.G. Efficiency and fuel utilization of methane-powered single-chamber solid oxide fuel cells. J. Power Sources 2008, 183, 157-163.

90. Kuhn, M. Direct-write microfabrication and characterization of single-chamber micro solid oxide fuel cells with coplanar electrodes. Ph.D. thesis, École Polytechnique de Montréal, Canada, 2009.

91. Akhtar, N.; Decent, S.P.; Loghin, D.; Kendall, K. Mixed-reactant, micro-tubular solid oxide fuel cells: An experimental study. J. Power Sources 2009, 193, 39-48.

92. Morel, B.; Roberge, R.; Savoie, S.; Napporn, T.W.; Meunier, M. An experimental evaluation of the temperature gradient in solid oxide fuel cells. Electrochem. Solid-State Lett. 2007, 10, B31-B33.

93. Hibino, T.; Hashimoto, A.; Inoue, T.; Tokuno, J.I.; Yoshida, S.I.; Sano, M. A solid oxide fuel cell using an exothermic reaction as the heat source. J. Electrochem. Soc. 2001, 148, A544A549.

94. Morel, B.; Roberge, R.; Savoie, S.; Napporn, T.W.; Meunier, M. Temperature and performance variations along single chamber solid oxide fuel cells. J. Power Sources 2009, 186, 89-95.

95. Akhtar, N.; Decent, S.P.; Kendall, K. Cell Temperature measurements in micro-tubular, single-chamber, solid oxide fuel cells (MT-SC-SOFCs). J. Power Sources 2009, doi:10.1016/j.jpowsour.2009.04.078.

96. Jacques-Bedard, X.; Napporn, T.W.; Roberge, R.; Meunier, M. Performance and ageing of an anode-supported SOFC operated in single-chamber conditions. J. Power Sources 2006, 153, 108-113.

97. Stefan, I.C.; Jacobson, C.P.; Visco, S.J.; De Jonghe, L.C. Single chamber fuel cells: flow geometry, rate and composition considerations. Electrochem. Solid-State Lett. 2004, 7, A198-A200.

98. Rotureau, D.; Viricelle, J.P.; Pijolat, C.; Caillol, N.; Pijolat, M., Development of a planar SOFC device using screen-printing technology. Journal of the European Ceramic Society 2005, 25, 2633-2636.

99. Buergler, B.E.; Siegrist, M.E.; Gauckler, L.J. Single chamber solid oxide fuel cells with mixed ionic electronic conducting electrolyte. In Proceedings of the 5th International Symposium on Ionic and Mixed Conducting Ceramics, Honolulu, Hawaii, USA, Oct. 2004; p. 1748.

100. Buergler, B.E.; Siegrist, M.E.; Gauckler, L.J. Single chamber solid oxide fuel cells with integrated current collectors. In Proceedings of the 6th European Solid Oxide Fuel Cell Forum, Lucerne, Switzerland, June, 2004; pp. 1405-1413.

101. Buergler, B.E.; Siegrist, M.E.; Gauckler, L.J. Single chamber solid oxide fuel cells with integrated current-collectors. Solid State Ionics 2005, 176, 1717-1722.

102. Akhtar, N.; Decent, S.P.; Kendall, K. Structural stability of silver under single-chamber solid oxide fuel cell conditions. Int. J. Hydrogen Energy 2009, 34, 7807-7810.

103. Buergler, B.E.; Ochsner, M.; Vuillemin, S.; Gauckler, L.J. From macro- to micro-single chamber solid oxide fuel cells. J. Power Sources 2007, 171, 310-320.

104. Kuhn, M.; Napporn, T.W.; Meunier, M.; Therriault, D. Experimental study of current collection in single-chamber micro solid oxide fuel cells with comblike electrodes. J. Electrochem. Soc. 2008, 155, B994-B1000.

105. Zabetakis, M.G. Flammability characteristics of combustible gases and vapors. Bulletin 627; U.S. Department of the Interior, Bureau of Mines: 1965.

106. Crowl, D.A. Understanding explosions; Wiley-AIChE: New York, USA, 2003.

107. Hibino, T.; Ushiki, K.; Sato, T.; Kuwahara, Y. A novel design for simplifying SOFC system. Solid State Ionics 1995, 81, 1-3. 
108. Hibino, T.; Asano, K.; Iwahara, H. Solid oxide fuel-cell which can work in uniform-gas phase using partial oxidation of methane. Nippon Kagaku Kaishi 1994, 7, 600-604.

109. Hibino, T.; Asano, K.; Iwahara, H. Improvement of Capcius cell using $\mathrm{SrCe}_{0.95} \mathrm{Yb}_{0.05} \mathrm{O}_{3-\mathrm{a}}$ as a solid electrolyte. Chem. Lett. 1994, 3, 485-488.

110. Hibino, T. Novel SOFC system free from a separator and gas seal. Seramikkusu 1995, 30, 337-340.

111. Iwahara, H. A one-chamber solid electrolyte fuel cell for chemical cogeneration. Ionics 1998, 4 , 409-414.

112. Asano, K.; Hibino, T.; Iwahara, H. Studies on solid electrolytes for a new-type SOFC using methane-air mixture. Denki kagaku oyobi kogyo butsuri kagaku 1996, 64, 649-653.

113. Asano, K.; Iwahara, H. Performance of a one-chamber solid oxide fuel cell with a surface-modified zirconia electrolyte. J. Electrochem. Soc. 1997, 144, 3125-3130.

114. Hibino, T.; Kuwahara, Y.; Wang, S. Effect of electrode and electrolyte modification on the performance of one-chamber solid oxide fuel cell. J. Electrochem. Soc. 1999, 146, 2821-2826.

115. Wang, S.; Hibino, T. One-chamber SOFC using Ni/LSGM/LSM cell. In Proceedings of the 6th FCDIC Fuel Cell Symposium, Tokyo, Japan, May, 1999; pp. 139-143.

116. Hibino, T. Single chamber solid electrolyte fuel cell. Japanese Patent JP2000243412A, 2000.

117. Hibino, T.; Tsunekawa, H.; Tanimoto, S.; Sano, M. Improvement of a single-chamber solid-oxide fuel cell and evaluation of new cell designs. J. Electrochem. Soc. 2000, 147, 1338-1343.

118. Jasinski, P.; Suzuki, T.; Dogan, F.; Anderson, H.U. Impedance spectroscopy of single chamber SOFC. Solid State Ionics 2004, 175, 35-38.

119. Lamas, D.G.; Cabezas, M.D.; Fabregas, I.O.; de Reca, N.E.; Lascalea, G.E.; Kodjaian, A.; Vidal, M.A.; Amadeo, N.E.; Larrondo, S.A. NiO/ZrO $2-\mathrm{CeO}_{2}$ anodes for single-chamber solid-oxide fuel cells operating on methane/air mixtures. ECS Trans. 2007, 7, 961-970.

120. Larrondo, S.A.; Kodjaian, A.; Fabregas, I.; Zimicz, M.G.; Lamas, D.G.; Walsoe de Reca, B.E.; Amadeo, N.E. Methane partial oxidation using Ni/Ce ${ }_{0.9} \mathrm{Zr}_{0.1} \mathrm{O}_{2}$ catalysts. Int. J. Hydrogen Energy 2008, 33, 3607-3613.

121. Cabezas, M.D.; Lamas, D.G.; Bellino, M.G.; Fuentes, R.O.; de Reca, N.E. Performance of single-chamber intermediate-temperature SOFCs operated in methane/air mixtures using $\mathrm{PdO} / \mathrm{NiO} / \mathrm{CeO}_{2}-\mathrm{Sm}_{2} \mathrm{O}_{3}$ anodes. ECS Trans. 2007, 7, 955-960.

122. Choi, S.H.; Kim, W.S.; Jung, H.Y.; Ahn, S.J.; Lee, J.H.; Lee, H.W.; Kim, J. Structure and conducting properties of porous $\mathrm{NiO}$ films for single chamber micro-solid oxide fuel cell. In Proceedings of 207th Meeting of the Electrochemical Society, Quebec City, Canada, May, 2005; pp. 812.

123. van Rij, L.N.; Le, J.; van Landschoot, R.C.; Schoonman, J. A novel Ni-CERMET electrode based on a proton conducting electrolyte. J. Mater. Sci. 2001, 36, 1069-1076.

124. Jou, S.; Wu, T. H. Thin porous Ni-YSZ films as anodes for a solid oxide fuel cell. J. Phys. Chem. Solids 2008, 69, 2804-2812.

125. Jasinski, P.; Suzuki, T.; Zhou, X.D.; Dogan, F.; Anderson, H.U. Single chamber solid oxide fuel cell - investigation of cathodes. Ceram. Eng. Sci. Proc. 2003, 24, 293-298.

126. Suzuki, T.; Jasinski, P.; Dogan, F.; Anderson, H.U. Role of cathode in single chamber SOFC. Ceram. Eng. Sci. Proc. 2003, 24, 257-261.

127. Dogan, F.; Suzuki, T.; Jasinski, P.; Anderson, H.U. Effect of cathode materials on the performance of single chamber solid oxide fuel cells and module. Ceram. Trans. 2005, 169, $39-47$.

128. Suzuki, T.; Jasinski, P.; Anderson, H.U.; Dogan, F. Role of composite cathodes in single chamber SOFC. J. Electrochem. Soc. 2004, 151, A1678-A1682.

129. Hori, M.; Nagasaka, K.; Miyayama, M. Evaluation of electrode performances of single-chamber solid oxide fuel cells. Key Eng. Mater. 2006, 301, 155-158. 
130. Magnone, E.; Traversa, E.; Miyayama, M. Synthesis and characterization of strontium and iron-doped lanthanum cobaltite nanocrystalline powders for single chamber solid oxide fuel cells. In Proceedings of Electrochemical Society, Solid Oxide Fuel Cells IX: Materials, Quebec City, Canada, May, 2005; pp. 1617-1626.

131. Deganello, F.; Esposito, V.; Traversa, E.; Miyayama, M. Electrode performance of nanostructured $\mathrm{La}_{1-\mathrm{a}} \mathrm{Sr}_{\mathrm{a}} \mathrm{Co}_{1-\mathrm{b}} \mathrm{Fe}_{\mathrm{b}} \mathrm{O}_{3-\mathrm{x}}$ on a $\mathrm{Ce}_{0.8} \mathrm{Sm}_{0.2} \mathrm{O}_{2}$ electrolyte prepared by citrate nitrate auto-combustion. ECS Trans. 2006, 1, 219-232.

132. Deganello, F.; Esposito, V.; Miyayama, M.; Traversa, E. Cathode performance of nanostructured $\mathrm{La}_{1-\mathrm{a}} \mathrm{Sr}_{\mathrm{a}} \mathrm{Co}_{1-\mathrm{b}} \mathrm{Fe}_{\mathrm{b}} \mathrm{O}_{3-\mathrm{x}}$ on a $\mathrm{Ce}_{0.8} \mathrm{Sm}_{0.2} \mathrm{O}_{2}$ electrolyte prepared by citrate-nitrate autocombustion. J. Electrochem. Soc. 2007, 154, A89-A96.

133. Ruiz de Larramendi, I.; Lamas, D.G.; Cabezas, M.D.; Ruiz de Larramendi, J.I.; Walsöe de Reca, N.E.; Rojo, T. Development of electrolyte-supported intermediate-temperature single-chamber SOFCs using $\mathrm{Ln}_{0.7} \mathrm{Sr}_{0.3} \mathrm{Fe}_{0.8} \mathrm{Co}_{0.2} \mathrm{O}_{3-\mathrm{d}}(\mathrm{Ln}=\mathrm{Pr}, \mathrm{La}, \mathrm{Gd})$ cathodes. J. Power Sources 2009, 193, 774-778.

134. Lalanne, C. Synthèse et mise en forme de nouveaux matériaux de cathode pour piles ITSOFC: réalisation et tests de cellules. Ph.D. thesis, Université de Bordeaux, France, 2005.

135. Pinol, S. Stable single-chamber solid oxide fuel cells based on doped ceria electrolytes and $\mathrm{La}_{0.5} \mathrm{Sr}_{0.5} \mathrm{CoO}_{3}$ as a new cathode. J. Fuel Cell Sci. Technol. 2006, 3, 434-437.

136. Morales, M.; Piñol, S.; Segarra, M. Intermediate temperature single-chamber methane fed SOFC based on $\mathrm{Gd}$ doped ceria electrolyte and $\mathrm{La}_{0.5} \mathrm{Sr}_{0.5} \mathrm{CoO}_{3-\mathrm{d}}$ as cathode. J. Power Sources 2009, 194, 961-966.

137. Hibino, T. Single-chamber SOFCs capable of operating in hydrocarbon-air mixtures. Seramikkusu 2001, 36, 486-488.

138. Asahara, S.; Michiba, D.; Hibino, M.; Yao, T. Single chamber SOFC using BaLaIn $\mathrm{O}_{5.5}$ solid electrolyte. Electrochem. Solid-State Lett. 2005, 8, 449-451.

139. Buergler, B.E.; Santschi, Y.; Felberbaum, M.; Gauckler, L.J. Influence of anode thickness on the electrochemical performance of single chamber solid oxide fuel cells. Ceram. Eng. Sci. Proc. 2006, 27, 37-45.

140. Morel, B.; Savoie, S.; Roberge, R.; Napporn, T.W.; Meunier, M. Ni-YSZ reduction process under $\mathrm{CH}_{4}$ in a single-chamber SOFC. In Proceedings of the 7th European SOFC Forum, Lucerne, Switzerland, July, 2006.

141. Suzuki, T.; Jasinski, P.; Anderson, H.U.; Dogan, F. Single chamber electrolyte supported SOFC module. Electrochem. Solid-State Lett. 2004, 7, A391-A393.

142. Yano, M.; Nagao, M.; Okamoto, K.; Tomita, A.; Uchiyama, Y.; Uchiyama, N.; Hibino, T. A single-chamber SOFC stack operating in engine exhaust. Electrochem. Solid-State Lett. 2008, 11, B29-B33.

143. Nagao, M.; Yano, M.; Okamoto, K.; Tomita, A.; Uchiyama, Y.; Uchiyama, N.; Hibino, T. A single-chamber SOFC stack: Energy recovery from engine exhaust. Fuel Cells 2008, 8, 322-329.

144. Ai, G.; Lu, Z.; Wei, B.; Huang, X.Q.; Chen, K.F.; Su, W.H. Performance of anode-supported single-chamber solid oxide fuel cells. Chin. J. Catal. 2006, 27, 885-889.

145. Shao, Z.; Mederos, J.; Chueh, W.C.; Haile, S.M. High power-density single-chamber fuel cells operated on methane. J. Power Sources 2006, 162, 589-596.

146. Tomita, A.; Hirabayashi, D.; Hibino, T.; Nagao, M.; Sano, M. Single-chamber SOFCs with a $\mathrm{Ce}_{0.9} \mathrm{Gd}_{0.1} \mathrm{O}_{1.95}$ electrolyte film for low-temperature operation. Electrochem. Solid-State Lett. 2005, 8, A63-A65.

147. Hibino, T.; Hashimoto, A.; Suzuki, M.; Yano, M.; Yoshida, S.I.; Sano, M. A solid oxide fuel cell with a novel geometry that eliminates the need for preparing a thin electrolyte film. J. Electrochem. Soc. 2002, 149, A195-A200.

148. Jacques-Bedard, X. Conception et caractérisation de piles à électrolyte d'oxyde solide fonctionnant en chambre unique. M.Sc. thesis, École Polytechique de Montréal, Canada, 2005. 
149. Kuhn, M.; Napporn, T.; Meunier, M.; Vengallatore, S.; Therriault, D. Direct-write microfabrication of single-chamber micro solid oxide fuel cells. J. Micromech. Microeng. 2008, 18, $015005-015013$.

150. Jacques-Bedard, X.; Napporn, T.W.; Roberge, R.; Meunier, M. Coplanar electrodes design for a single-chamber SOFC: Assessment of the operating parameters. J. Electrochem. Soc. 2007, 154, B305-B309.

151. Kuhn, M.; Napporn, T.W.; Meunier, M.; Vengallatore, S.; Therriault, D. Miniaturization limits for single-chamber micro solid oxide fuel cells with coplanar electrodes. J. Power Sources 2009, 194, 941-949.

152. Pinol, S.; Segarra, M.; Capdevila, X. Preparation and electrical properties of intermediate temperature one chamber solid oxide fuel cells based on ceria electrolytes. In Proceedings of the 1st European Fuel Cell Technology and Applications Conference, Rome, Italy, December, 2005; p. 201.

153. Pinol, S.; Morales, M.; Espiell, F. Low temperature anode-supported solid oxide fuel cells based on gadolinium doped ceria electrolytes. J. Power Sources 2007, 169, 2-8.

154. Shao, Z.; Haile, S.M. A high-performance cathode for the next generation of solid-oxide fuel cells. Nature 2004, 431, 170-173.

155. Zhang, C.; Zheng, Y.; Lin, Y.; Ran, R.; Shao, Z.; Farrusseng, D. A comparative study of $\mathrm{La}_{0.8} \mathrm{Sr}_{0.2} \mathrm{MnO}_{3}$ and $\mathrm{La}_{0.8} \mathrm{Sr}_{0.2} \mathrm{Sc}_{0.1} \mathrm{Mn}_{0.9} \mathrm{O}_{3}$ as cathode materials of single-chamber SOFCs operating on a methane-air mixture. J. Power Sources 2009, 191, 225 -232.

156. Wei, B.; Lu, Z.; Huang, X.; Liu, M.; Chen, K.; Su, W. Enhanced performance of a single-chamber solid oxide fuel cell with an SDC-impregnated cathode. J. Power Sources 2007, 167, 58-63.

157. Liu, M.; Lü, Z.; Wei, B.; Huang, X.; Chen, K.; Su, W. Study on impedance spectra of $\mathrm{La}_{0.7} \mathrm{Sr}_{0.3} \mathrm{MnO}_{3}$ and $\mathrm{Sm}_{0.2} \mathrm{Ce}_{0.8} \mathrm{O}_{1.9}$-impregnated $\mathrm{La}_{0.7} \mathrm{Sr}_{0.3} \mathrm{MnO}_{3}$ cathode in single chamber fuel cell condition. Electrochim. Acta 2009, 54, 4726-4730.

158. Haile, S.M.; Shao, Z. Barium strontium cobalt iron oxide based perovskite mixed conducting materials as cathode materials for intermediate temperature solid oxide fuel cells both in dual chamber and single chamber configuration. Patent WO2005001958-A2, 2005.

159. Ahn, J.; Ronney, P.D.; Shao, Z.; Haile, S.M. A thermally self-sustaining miniature solid oxide fuel cell. In Proceedings of the 5th International Energy Conversion Engineering Conference, St. Louis, MI, USA, June, 2007.

160. Ahn, J.; Shao, Z.; Ronney, P.D.; Haile, S.M. A thermally self-sustaining miniature solid oxide fuel cell. In Proceedings of the ASME International Mechanical Engineering Congress and Exposition, Seattle, WA, USA, November, 2007; pp. 117-122.

161. Hao, Y.; Shao, Z.; Mederos, J.; Lai, W.; Goodwin, D.G.; Haile, S.M. Recent advances in single-chamber fuel-cells: Experiment and modeling. Solid State Ionics 2006, 177, 2013-2021.

162. Zhang, C.; Zheng, Y.; Ran, R.; Shao, Z.; Jin, W.; Xu, N.; Ahn, J. Initialization of a methane-fueled single-chamber solid-oxide fuel cell with $\mathrm{NiO}+$ SDC anode and BSCF + SDC cathode. J. Power Sources 2008, 179, 640-648.

163. Tomita, A.; Teranishi, S.; Nagao, M.; Hibino, T.; Sano, M. Comparative performance of anode-supported SOFCs using a thin $\mathrm{Ce}_{0.9} \mathrm{Gd}_{0.1} \mathrm{O}_{1.95}$ electrolyte with an incorporated $\mathrm{BaCe}_{0.8} \mathrm{Y}_{0.2} \mathrm{O}_{3-\mathrm{a}}$ layer in hydrogen and methane. J. Electrochem. Soc. 2006, 153, A956-A960.

164. Ahn, J.; Ronney, P.D.; Shao, Z.; Haile, S.M. A thermally self-sustaining miniature solid oxide fuel cell. J. Fuel Cell Sci. Technol. 2009, 6, 041004-041007.

165. Song, H.S.; Min, J.H.; Kim, J.; Moon, J. Phase stability of $\mathrm{Sm}_{0.5} \mathrm{Sr}_{0.5} \mathrm{CoO}_{3}$ cathodes for on-planar type, single-chamber, solid oxide fuel cells. J. Power Sources 2009, 191, 269-274.

166. Liu, M.; Lu, Z.; Wei, B.; Huang, X.; Chen, K.; Su, W. Effect of the cell distance on the cathode in single chamber SOFC short stack. J. Electrochem. Soc. 2009, 156, B1253-B1256.

167. Wei, B.; Lü, Z.; Huang, X.; Liu, M.; Jia, D.; Su, W. A novel design of single-chamber SOFC micro-stack operated in methane-oxygen mixture. Electrochem. Commun. 2009, 11, 347-350. 
168. Hertz, J.; Tuller, H.L. Single chamber solid oxide fuel cell comprises planar electrolyte layer; planar selectively active cathode contacting electrolyte layer and planar selectively active anode contacting electrolyte layer, all layers having specific thickness. Patent WO2007024907-A2, 2007.

169. Kamijo, M.; Rouveyre, L. Solid oxide fuel cell for electric power generation, has several air holes that are located in electrolyte such that mixed gas of fuel gas circulates in air holes. Japanese Patent JP2007242429-A, 2007.

170. Anderson, H.; Suzuki, T.; Jasinski, P.; Petrovsky, V. Electrochemical energy extraction from hydrocarbon fluids to convert potential energy to electricity comprises positioning anode and cathode layers on porous, non-densified yttria-doped zirconia electrolyte substrate. US Patent US2008038592-A1, 2008.

171. Nagata, A.; Kimura, T. Selective control of voltage polarity in a single-chamber solid-oxide fuel cell using the same catalytic electrodes with different sizes. IEEJ Trans. Electr. Electron. Eng. 2008, 3, 569-573.

172. Kim, H.; Choi, S.H.; Kim, W.S.; Lee, J.H.; Lee, H.W.; Kim, J. Development of single chamber solid oxide fuel cells with coplanar micro-electrode array. In Proceedings of the 207th Meeting of the Electrochemical Society, Quebec, Canada, May, 2005; p. 1213.

173. Fleig, J.; Tuller, H.L.; Maier, J. Electrodes and electrolytes in micro-SOFCs: A discussion of geometrical constraints. Solid State Ionics 2004, 174, 261-270.

174. Hibino, T.; Ushiki, K.; Kuwahara, Y. New concept for simplifying SOFC system. Solid State Ionics 1996, 91, 69-74.

175. Tomita, A.; Namekata, Y.; Nagao, M.; Hibino, T. Room-temperature hydrogen sensors based on an $\mathrm{In}^{3+}$-Doped $\mathrm{SnP}_{2} \mathrm{O}_{7}$ Proton Conductor. J. Electrochem. Soc. 2007, 154, J172-J176.

176. Yoshikata, K.; Sakamoto, H. Base material for solid oxide fuel cell, has several polygonal or circular shaped fuel elctrodes and air elecrodes, arranged on surface of electrolyte. Japanese Patent JP2006004672-A, 2006.

177. Kuhn, M.; Napporn, T.; Meunier, M.; Therriault, D.; Vengallatore, S. Fabrication and testing of coplanar single-chamber micro solid oxide fuel cells with geometrically complex electrodes. J. Power Sources 2008, 177, 148-153.

178. Kearl, D.A.; Peterson, R.B. Single chamber solid oxide fuel cell architecture for high temperature operation. US Patent US2003190505, 2003.

179. Kearl, D.A.; Peterson, R.B. Single chamber solid oxide fuel cell architecture for high temperature operation. US Patent US20050238946A1, 2005.

180. Ahn, S.J.; Kim, Y.B.; Moon, J.; Lee, J.H.; Kim, J. Influence of patterned electrode geometry on performance of co-planar type single chamber SOFC. J. Power Sources 2007, 171, 511-516.

181. Chung, C.Y.; Chung, Y. C. Computational modeling of the performance characteristics of micro scale single-chamber IT-SOFC system. In Proceedings of Electrochemical Society - SOFC IX, Quebec City, Canada, May, 2005; pp. 670-678.

182. Chung, C.Y.; Chung, Y.C.; Kim, J.; Lee, J.; Lee, H.W. Numerical modeling of micro single-chamber ceria-based SOFC. J. Electroceram. 2006, 17, 959-964.

183. Chung, C.Y.; Chung, Y.C. Performance characteristics of micro single-chamber solid oxide fuel cell: Computational analysis. J. Power Sources 2006, 154, 35-41.

184. Son, J.W.; Ahn, S.J.; Kim, S.M.; Kim, H.; Choi, S.H.; Moon, J.; Kim, H.R.; Kim, S.E.; Lee, J.H.; Lee, H.W.; Kim, J. Fabrication and operation of co-planar type single chamber solid oxide fuel cells. In Proceedings of the 7th European SOFC Forum, Lucerne, Switzerland, July, 2006.

185. Ahn, S.J.; Kim, Y.B.; Moon, J.; Lee, J.H.; Kim, J. Co-planar type single chamber solid oxide fuel cell with micro-patterned electrodes. J. Electroceram. 2006, 17, 689-693.

186. Crumlin, E.J.; La O, G.J.; Shao-Horn, Y. Architectures and performance of high-voltage, microscale single-chamber solid oxide fuel cell stacks. ECS Trans. 2007, 7, 981-986.

187. Lee, H.W.; Kim, E.K.; Son, J.W.; Kim, H.C.; Kim, H.R.; Kim, J.S.; Lee, J.H.; Song, H.S. Single-chamber solid oxide fuel cell having partition interposed between two homogeneous or 
heterogeneous electrodes and method for manufacturing the same. Korean Patent KR724120-B1, 2008.

188. Kim, H.C.; Lee, H.W.; Kim, S.M.; Song, H.S.; Lee, J.H.; Kim, J.S.; Son, J.W.; Ahn, S.J. Single-chamber solid oxide fuel cell using partition formed on one surface of electrolyte and interposed between two electrodes. Korean Patent KR724119-B1, 2008.

189. Ahn, S.J.; Lee, J.H.; Kim, J.; Moon, J. Single-chamber solid oxide fuel cell with micropatterned interdigitated electrodes. Electrochem. Solid-State Lett. 2006, 9, A228-A231.

190. Min, J.H.; Ahn, S.J.; Moon, J.; Kim, J.; Lee, H.W. Single-chamber mini-solid oxide fuel cells operated at a lower temperature. ECS Trans. 2007, 7, 947-953.

191. Jasinski, P., Micro solid oxide fuel cells and their fabrication methods. Microelectron. Int. 2008, $25,42-48$

192. Kuhn, M.; Napporn, T.W.; Meunier, M.; Therriault, D. Single-chamber micro solid oxide fuel cells: Study of anode and cathode materials in coplanar electrode design. Solid State Ionics 2009, submitted.

193. Yang, C.C. T.; Wei, W.C. J.; Roosen, A. Reaction kinetics and mechanisms between $\mathrm{La}_{0.65} \mathrm{Sr}_{0.3} \mathrm{MnO}_{3}$ and $8 \mathrm{~mol} \%$ yttria-stabilized zirconia. J. Am. Ceram. Soc. 2004, 87, 1110-1116.

194. Nagata, A.; Nosaka, H.; Yoshimura, Y.; Kimura, T. Room temperature operation of surface-conduction single chamber fuel cell using a novel inorganic electrolyte as proton conductor. IEEJ Trans. Electr. Electron. Eng. 2008, 3, 593-595.

195. Choi, S.H.; Hwang, C.S.; Lee, H.W.; Kim, J. Fabrication of Gd2O3-doped CeO2 thin films for single-chamber-type solid oxide fuel cells and their characterization. J. Electrochem. Soc. 2009, 156, B381-B385.

196. Coia, C. Fabrication et caracterisation d'une micro-pile a combustible a electrolyte oxyde solide. M.Sc. thesis, École Polytechnique de Montréal, Canada, 2002.

197. Bieberle-Hutter, A.; Sogaard, M.; Tuller, H. L., Electrical and electrochemical characterization of microstructured thin film $\mathrm{La}_{1-\mathrm{x}} \mathrm{Sr}_{\mathrm{x}} \mathrm{CoO}_{3}$ electrodes. Solid State Ionics 2006, 177, 1969-1975.

198. Viricelle, J. P.; Pijolat, C.; Riviere, B.; Rotureau, D.; Briand, D.; de Rooij, N. F. Compatibility of screen-printing technology with micro-hotplate for gas sensor and solid oxide micro fuel cell development. Sens. Actuators, B 2006, 118, 263-268.

199. Ahn, S.J.; Moon, J. Vacuum-assisted microfluidic lithography of ceramic microstructures. J. Am. Ceram. Soc. 2005, 88, 1171-1174.

200. Moon, J.H.; Ahn, S.J. Micro-patterning method, micro-pattern substrate, and single chamber solid oxide fuel cell manufactured thereby. Korean Patent KR2006038649-A, 2006.

201. Ahn, S.J.; Lee, J.H.; Kim, J.; Moon, J. Single-chamber solid oxide fuel cell with micropatterned interdigitated electrodes. In Proceedings of Electrochemical Society - SOFC IX, Quebec City, Canada, May, 2005; pp. 378-383.

202. Moon, J.H.; Kim, Y.B.; Kim, J.S. Preparation method of electrochemical cell by preparing paste and substrate, and patterning the paste on the substrate by robo-dispensing, and solid oxide fuel cell prepared by the method. Korean Patent KR2007015731-A, 2007.

203. Kim, H.C.; Park, J.K.; Lee, H.W.; Lee, J.H.; Kim, J.S.; Son, J.W.; Choi, S.H. Single chamber solid oxide fuel cell with isolated electrolyte. Patent WO2007073015-A1, 2007.

204. Kuhn, M.; Napporn, T.; Meunier, M.; Therriault, D.; Vengallatore, S. Direct-write microfabrication of single-chamber solid oxide fuel cells with interdigitated electrodes. Mater. Res. Soc. Symp. Proc. 2007, 972, 211-216.

205. Kuhn, M.; Rao, B.R.; Therriault, D. Viscoelastic inks for direct-write microfabrication of single-chamber micro solid oxide fuel cells with coplanar thick electrodes. Mater. Res. Soc. Symp. Proc. 2009, 1179, 111-116.

206. Kim, Y.B.; Ahn, S.J.; Moon, J.; Kim, J.; Lee, H.W. Direct-write fabrication of integrated planar solid oxide fuel cells. J. Electroceram. 2006, 17, 683-687. 
207. Yoshikata, K.; Sakamoto, H. Solid-acid compound type fuel cell has interconnectors arranged in through-holes formed in electrolyte, for connecting air electrodes and fuel electrodes arranged on both surfaces of electrolyte. Japanese Patent JP2005310501-A, 2005.

208. Yoshikata, K.; Sakamoto, H. Single chambered solid oxide fuel cell has interconnector used for attaching air electrode and fuel electrode so that adjacent single cell are connected in series. Japanese Patent JP2006221884-A, 2005.

209. Lu, Z.; Su, W.; Liu, J.; Huang, X.; Liu, Z.; Miao, J.; Li, C. Battery composed of single-chamber solid oxide fuel cells (SOFCs). Chinese Patent CN1564361, 2005.

210. Hibino, T.; Ushiki, K.; Kuwabara, Y. Non-diaphragm solid electrolyte type fuel cell for co-generation. Japanese Patent JP8264195, 1996.

211. Zhu, B.; Meng, G.; Mellander, B.E. Non-conventional fuel cell systems: new concepts and development. J. Power Sources 1999, 79, 30-36.

212. Larminie, J.; Dicks, A. Fuel cell systems explained; John Wiley \& Sons: Chichester, UK, 2000.

213. Koh, Y.H.; Sun, J.J.; Choi, W.Y.; Kim, H.E. Design and fabrication of three-dimensional solid oxide fuel cells. J. Power Sources 2006, 161, 1023-1029.

214. Hao, Y.; Pantano, C.; Goodwin, D.G. A single-chamber solid oxide fuel cell model with detailed chemistry. In Proceedings of the Fourth Joint Meeting of the U.S. Sections of the Combustion Institute: Western States, Central States, Eastern States, Philadelphia, PA, United States, March 2005; pp. B39/31-B39/36.

215. Hao, Y.; Pantano, C.; Goodwin, D.G. A two-dimensional model of a single-chamber SOFC with hydrocarbon fuels. In Proceedings of Electrochemical Society - SOFC IX, Quebec City, Canada, May, 2005; pp. 771-779.

216. Hao, Y.; Goodwin, D.G. Numerical modeling of single-chamber SOFCs with hydrocarbon fuels. J. Electrochem. Soc. 2007, 154, B207-B217.

217. Akhtar, N.; Decent, S.P.; Loghin, D.; Kendall, K. An isothermal numerical model of single-chamber solid oxide fuel cells. In Proceedings of the 8th European SOFC Forum, Lucerne, Switzerland, 2008; B0715, Abstract 003.

218. Hao, Y.; Goodwin, D.G. Numerical study of heterogeneous reactions in an SOFC anode with oxygen addition. J. Electrochem. Soc. 2008, 155, B666-B674.

219. Hao, Y.; Goodwin, D.G. Numerical study of heterogeneous reactions in an SOFC anode with oxygen addition. ECS Trans. 2007, 7, 1859-1867.

220. Shiratori, Y.; Yamazaki, Y. A novel high-voltage single-chamber SOFC with series connected cells. I. Operating characteristics of two-segments cell. In Proceedings of Electrochemical Society - SOFC VII, Lucerne, Switzerland, July, 2006; pp. 1012-1021.

221. Shiratori, Y.; Yamazaki, Y. Study of high voltage single chamber SOFC with series connected cells I. IV-IP characteristics of two segments cell. Electrochem. 2001, 69, 92-97.

222. Uchiyama, N. Single chamber type solid oxide fuel cell for motor vehicle, has solid oxide fuel cell unit accommodated inside exhaust-gas flow path of internal combustion engine. Patent WO2007094262-A1, 2007.

223. Evans, J. Anon Fuel cells that don't feel the cold. Chem. World 2005, 2, 20.

224. Nikbin, D. Micro SOFCs: why small is beautiful. Fuel Cell Rev. 2006, 3, 21-24.

225. Horiuchi, M.; Tokutake, Y.; Suganuma, S.; Yoshiike, J.; Katagiri, F. Solid oxide fuel cell. US Patent US2008187806A1, 2007.

226. Weingaertner, D.; Kalika, V.; Wiser, C. Fuel cell system e.g. solid oxide fuel cell (SOFC) system has venturi with apertures for radially injecting fluid for mixing with air to deliver air-fuel mixture to catalytic reactor. US Patent US2008187794-A1, 2008.

227. Lazaroff, D.; Mardilovich, P.; Champion, D.; Herman, G.S. Fuel cell manufacture e.g. for solid oxide fuel cell used in e.g. computer, involves performing chemical mechanical planarization to remove anode, electrolyte and cathode layers formed on specific topographic pattern. US Patent US20040086754-A1, 2004. 
228. Kawai, H. Single chambered fuel cell for use in e.g. motor vehicle, has main electrode layer with recesses in which sub-electrode layers whose height is identical with respect to height of convex surface of main electrode layer, are arranged. Japanese Patent JP2009087711-A, 2009.

229. Scheifers, S.M.; Klosterman, D.H.; Chason, M.K.; Wyatt, K.W. Portable fuel cell device including a water trap. US Patent US005723229A, 1998.

230. Yoshikata, K.; Sakamoto, H.; Kotani, K. Solid oxide fuel cell e.g. single-room type solid oxide fuel cell, has gas passageway that connects specific surface of board and fuel electrode formed on surface of board. Japanese Patent JP2007323957-A, 2007.

231. Yoshikata, K.; Sakamoto, H. Single chamber type solid oxide shape fuel cell Japanese Patent JP2006139960, 2006.

232. Kotani, K.; Yoshikata, K.; Sakamoto, H. Single-chamber solid oxide fuel cell has interconnector with hydrogen separation layer at fuel electrode side of unit cell. Japanese Patent JP2007273428-A, 2007.

233. Yoshikata, K.; Sakamoto, H.; Mikami, G. Single chamber type solid oxide fuel cell electric power generation system mixes fuel gas containing methane, and oxygen to used mixed gas ejected from electric power generator and circulates mixed gas to electric power generator. Japanese Patent JP2006114368-A, 2006.

234. Yoshikata, K.; Sakamoto, H.; Mikami, G. Single chamber-type solid oxide fuel cell electric power generation system has single chamber-type solid oxide fuel cell to eject circulation gas containing both fuel gas and oxidizing agent gas. Japanese Patent JP2006114373-A, 2006.

235. Yoshikata, K.; Kotani, K. Single-chambered solid oxide fuel cell has electrolyte extended downward along periphery of fuel electrode and air electrode of two different single cells respectively and connected to upper surface of porous substrate. Japanese Patent JP2008041540-A, 2008.

236. Kotani, K.; Yoshikata, K. Single-chambered solid oxide fuel cell for generating electric power, has single cells and electro-conductive porous substrate(s) inserted between adjoining single cells, and single cell comprises fuel electrode and air electrode. Japanese Patent JP2008060001-A, 2008.

237. Kotani, K.; Yoshikata, K. Single chamber solid oxide fuel cell has single cell consisting of air electrode as outermost layer and another single cell consisting of fuel electrode as outermost layer at both ends of porous block. Japanese Patent JP2008059869-A, 2008.

238. Yoshikata, K.; Kotani, K. Single chambered solid oxide fuel cell has dense substance substrate, single cell having fuel electrode, electrolyte and air electrode provided on electrolyte formed on fuel electrode, and porous substrate on air electrode. Japanese Patent JP2008077887-A, 2008.

239. Yoshikata, K.; Kotani, K. Single-chambered solid oxide fuel cell for electric power generation, has substrate and single cell(s) having air electrode formed on electrolyte formed on fuel electrode and communicating hole, formed on substrate. Japanese Patent JP2008047380-A, 2008.

240. Yoshikata, K.; Sakamoto, H.; Kotani, K. Jig for stack structure of single chamber solid oxide fuel cell, has pair of guides arranged at both sides of base and moving mechanism, so that moving mechanism is contacted/separated with respect to base. Japanese Patent JP2008034235-A, 2008.

241. Yoshikata, K.; Kotani, K. Jig for stack of single-chambered solid oxide fuel cell, has lower-side mesh element that extends in outer peripheral surface of supporting element which contacts fuel electrode of fuel cell. Japanese Patent JP2008084551-A, 2008.

242. Kotani, K.; Yoshikata, K. Stack structure of single chambered solid oxide fuel cell has buffer layer with cushioning properties, provided in side wall surface of recess opposite to fuel electrode and air electrode in single cell. Japanese Patent JP2008078069-A, 2008.

243. Kotani, K.; Yoshikata, K. Single chamber solid oxide fuel cell for electric power generation, has fuel electrode arranged in downstream side so as to allow gas to flow through air electrode arranged in upstream side. Japanese Patent JP2008084745-A, 2008. 
244. Yoshikata, K.; Kotani, K. Inter-connector of single chambered solid oxide fuel cell, consists of rectangular block which is formed with set of through holes that are connected together in specific order by gas flow channels. Japanese Patent JP2008226557-A, 2008.

245. Kotani, K.; Yoshikata, K. Solid oxide fuel cell has insulating electrolyte that covers fuel electrode and inner wall face of through-hole in porous substrate. Japanese Patent JP2008251241-A, 2008.

246. Yoshikata, K.; Kotani, K. Solid oxide fuel cell e.g. single room type fuel cell, for use as battery, has modified layer of porous positioning in through-hole, which has partial oxidation activity and supplied gas contacting fuel electrode through through-hole. Japanese Patent JP2008257885-A, 2008.

247. Yoshikata, K.; Kotani, K. Solid oxide fuel cell comprises electrolyte, fuel electrode which is arranged on electrolyte, air electrode which is spaced apart with fuel electrode and is arranged on electrolyte and modified layer which has partial oxidation activity. Japanese Patent JP2008257886-A, 2008.

248. Kotani, K.; Yoshikata, K. Single-chamber solid oxide fuel cell system has air electrode with left opening connected with supply pipe for supplying mixed gas to air electrode and right opening facing discharge pipe for discharging mixed gas from container. Japanese Patent JP2008251277-A, 2008.

249. Kotani, K.; Yoshikata, K. Single chamber solid oxide fuel cell for electric power generation, has vertical flow passages that are extended from horizontal gas flow passage in electrolyte between fuel electrode and air electrode. Japanese Patent JP2008251384-A, 2008.

(C) 2010 by the authors; licensee Molecular Diversity Preservation International, Basel, Switzerland. This article is an open-access article distributed under the terms and conditions of the Creative Commons Attribution license (http://creativecommons.org/licenses/by/3.0/). 